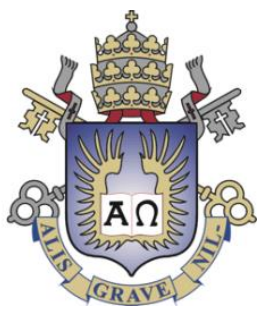

Renata Tomoe Mitsuya

Tratamento Biocida de Águas de Resfriamento com Ácido Peracético

Dissertação de Mestrado

Dissertação apresentada como requisito parcial para obtenção do grau de Mestre pelo Programa de Pós-graduação em Engenharia de Materiais e de Processos Químicos e Metalúrgicos da PUC-Rio.

Orientador: Prof. Luiz Alberto Cesar Teixeira Co-Orientador: Prof. Marco Antônio Lemos Miguel 


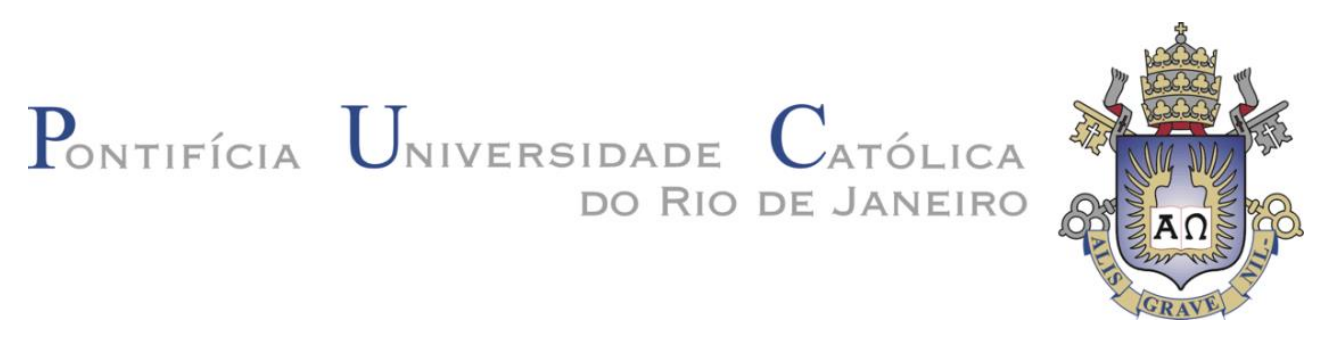

Renata Tomoe Mitsuya

\section{Tratamento Biocida de Águas de Resfriamento com Ácido Peracético}

Dissertação apresentada como requisito parcial para obtenção do grau de Mestre pelo Programa de Pósgraduação em Engenharia de Materiais e de Processos Químicos e Metalúrgicos da PUC-Rio. Aprovada pela Comissão Examinadora abaixo assinada.

Prof. Luiz Alberto Cesar Teixeira

Orientador

Departamento de Engenharia Química e de Materiais - PUC-Rio

Prof. Marco Antônio Lemos Miguel Co-Orientador Universidade Federal do Rio de Janeiro - UFRJ

Profa. Lídia Yokoyama Universidade Federal do Rio de Janeiro - UFRJ

Profa. Ana Rosa Fonseca de Aguiar Martins Departamento de Engenharia Química e de Materiais - PUC-Rio

Profa. Magali Christe Cammarota Universidade Federal do Rio de Janeiro - UFRJ

Prof. Mauricio Leonardo Torem Departamento de Engenharia Química e de Materiais - PUC-Rio

Prof. Marcio da Silveira Carvalho Coordenador Setorial do Centro Técnico

Científico - PUC-Rio

Rio de Janeiro, 25 de junho de 2018 
Todos os direitos reservados. É proibida a reprodução total ou parcial do trabalho sem autorização do autor, do orientador e da universidade.

\section{Renata Tomoe Mitsuya}

Graduou-se em Engenharia Ambiental e Sanitária pela Pontifícia Universidade Católica do Rio de Janeiro em 2015. Ingressou no mestrado na Pontifícia Universidade Católica do Rio de Janeiro em março de 2016, desenvolvendo dissertação na linha de pesquisa de Tecnologias Ambientais.

Ficha Catalográfica

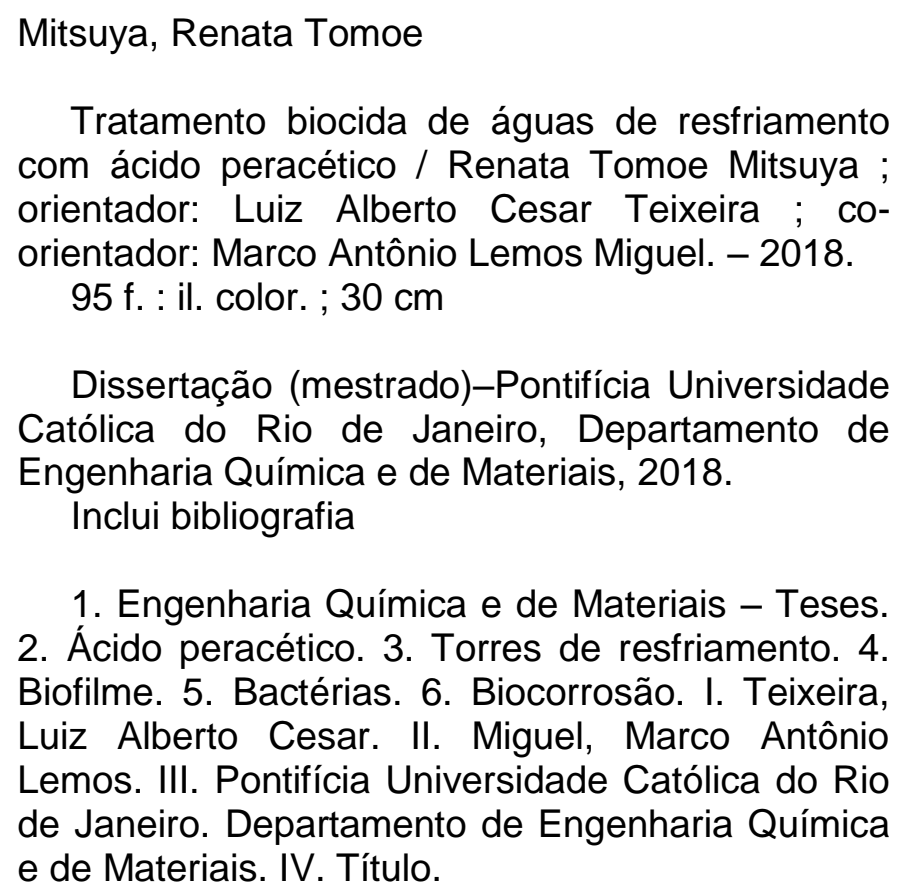

1. Engenharia Química e de Materiais - Teses. 2. Ácido peracético. 3. Torres de resfriamento. 4. Biofilme. 5. Bactérias. 6. Biocorrosão. I. Teixeira, Luiz Alberto Cesar. II. Miguel, Marco Antônio Lemos. III. Pontifícia Universidade Católica do Rio de Janeiro. Departamento de Engenharia Química e de Materiais. IV. Título. 
Ao meu pai, que sempre foi meu maior exemplo como pessoa e profissional. 


\section{Agradecimentos}

Aos meus orientadores, Luiz Alberto Cesar Teixeira, pelos contributivos ensinamentos na vida acadêmica, pelas críticas e sugestões ao presente trabalho e por dividir comigo a sua experiência em tratamento de águas e, Marco, pela ajuda e instruções em microbiologia, por ceder o laboratório e equipamentos para realização dos meus experimentos. Sem ele não seria possível a realização da pesquisa.

A todos do laboratório de Microbiologia de Alimentos da UFRJ pela compreensão, assistência e auxílio durante os meus experimentos, em especial ao Antonio, sempre muito solicito e disposto a ajudar.

A Peróxidos Brasil Ltda, em especial ao Eng. Wagner Zerbini e a Química Pércia Patrica, pelo apoio com os materiais e informações utilizados na presente pesquisa.

Ao eng. Edivaldo Silva, da Kurita pelas informações técnicas prestadas de tratamento de águas industriais.

Aos meus familiares por estarem sempre ao meu lado e não deixarem eu desistir dos meus sonhos.

Aos meus amigos pelo carinho, companheirismo e palavras de incentivo.

A todos os professores do mestrado pela dedicação e aprendizado que adquiri ao longo dessa jornada.

A Ana Cristina pela parceria nesses dois últimos anos e por todo apoio nas etapas experimentais do presente trabalho.

Aos demais colegas do laboratório de Tratamento de Águas e Efluentes Industriais da PUC-Rio, pela ajuda e apoio. 
A todos os colegas do mestrado que nesses dois anos sempre estiveram dispostos a ajudar.

Ao Caio por me entender, apoiar e não deixar eu desistir dos meus sonhos. Por acreditar mais em mim do que eu mesma.

A minha irmã e melhor amiga Fernanda, pelo constante incentivo e por sempre acreditar no meu potencial, por todas as conversas e conselhos.

Ao meu padrinho e segundo pai, por me escutar, pelo apoio de sempre, por sempre estar ao meu lado. Sem ele tudo seria mais difícil.

Por fim, um agradecimento especial aos meus pais: A minha mãe, por representar o meu maior exemplo como mulher e como pessoa. Sem ela não seria possível a realização desse sonho, e ao meu pai, que não está aqui fisicamente, mas está eternamente no meu coração. Sempre conversamos muito sobre minha profissão e meu futuro, e com ele aprendi a sempre dar o meu melhor. Não tenho palavras para agradecer a importância que meus pais sempre atribuíram a minha educação. 


\section{Resumo}

Mitsuya, Renata Tomoe; Teixeira, Luiz Alberto Cesar; Miguel, Marco Antônio Lemos. Tratamento de Águas de Resfriamento com Ácido Peracético. Rio de Janeiro, 2018. 95 p. Dissertação de Mestrado Departamento de Engenharia Química e de Materiais, Pontifícia Universidade Católica do Rio de Janeiro.

O objetivo deste estudo foi avaliar o efeito biocida do ácido peracético (APA) em águas de sistemas de resfriamento, de forma a buscar alternativas ao uso do cloro, que é corrosivo e reage com a matéria orgânica natural ou sintética presentes na água, formando subprodutos tóxicos. Para atingir este objetivo, experimentos utilizando amostras de água retiradas da bacia de uma torre de resfriamento de uma indústria química foram realizados. Ensaios foram executados utilizando-se uma solução comercial de APA, mantendo-se concentrações do biocida em 1,0 $\mathrm{mgL}^{-1}$ e 2,0 $\mathrm{mgL}^{-1}$ em pH 8,0 e 8,8. Cada condição de estudo foi monitorada ao longo de 5 dias, e contagens de bactérias heterotróficas mesófilas totais foram realizadas tanto antes da aplicação do biocida como em diferentes tempos de contato do biocida com a microbiota natural da água. Os tempos de contato monitorados foram de $5 \mathrm{~min}$, além de 1,2 e $4 \mathrm{~h}$ por dia considerando a aplicação do biocida em períodos totais de $4 \mathrm{~h}$ por dia. Com esta metodologia foi possível concluir que as duas dosagens aplicadas foram eficientes no combate aos microrganismos presentes naturalmente nas amostras de água, nos dois valores de pH estudados. A partir de uma carga microbiana natural da água de $10^{6}$ a $10^{7}$ UFC/mL, após o tratamento houve uma redução para contagens de no máximo de $10^{4} \mathrm{UFC} / \mathrm{mL}$ em todos os experimentos, limite máximo esse adotado pelas indústrias para carga microbiana em águas de sistemas de resfriamento, entretanto, houve maior eficiência, cerca de 10 vezes maior, quando $2,0 \mathrm{mgL}^{-1}$ de APA foi aplicado. Além disso, em pH 8,0 a ação do biocida também foi superior em 10 vezes em detrimento ao pH 8,8 para a mesma concentração de APA.

\section{Palavras-chave}

Ácido peracético; torres de resfriamento; biofilme; bactérias; biocorrosão. 


\section{Abstract}

Mitsuya, Renata Tomoe; Teixeira, Luiz Alberto Cesar (Advisor). Miguel, Marco Antônio Lemos (Co-Advisor). Cooling Water Biocidal Treatment using Peracetic Acid. Rio de Janeiro, 2018. 95 p. Dissertação de Mestrado Departamento de Engenharia Química e de Materiais, Pontifícia Universidade Católica do Rio de Janeiro.

The purpose of this study was to evaluate the biocidal effect of peracetic acid (PAA) in cooling water, in order to find alternatives to the use of chlorine, which is corrosive and reacts with natural and synthetic organic matter present in water, forming toxic byproducts. To achieve this goal, experiments using water samples taken from a basin of a chemical industry cooling tower were conducted. Experiments were performed using a commercial PAA solution, with concentrations of $1,0 \mathrm{mgL}^{-1}$ and 2,0 $\mathrm{mgL}^{-1}$ and $\mathrm{pH} \mathrm{8,0} \mathrm{and} \mathrm{8,8.} \mathrm{Each} \mathrm{study} \mathrm{condition}$ was monitored for 5 days and total mesophilic heterotrophic bacteria counts were made without biocide and after different contact times of the biocide and microorganisms present in water. The contact times were $5 \mathrm{~min}$, and 1, 2 and $4 \mathrm{~h}$ per day, considering the application of the biocide in total periods of $4 \mathrm{~h}$ per day. This methodology has allowed concluding that two dosages applied were efficient in controlling microorganisms at the two $\mathrm{pH}$ values. From a water natural microbial count of $10^{6}$ to $10^{7} \mathrm{UFC} / \mathrm{mL}$, after treatment there was a reduction to maximum counts to $10^{4} \mathrm{UFC} / \mathrm{mL}$ in all experiments, that being the upper limit adopted by industries for microorganisms in cooling water systems. However, the results were 10 times more efficient when $2,0 \mathrm{mgL}^{-1}$ of $\mathrm{PAA}$ were applied. In addition, at $\mathrm{pH}$ 8,0 the biocidal action was 10 times higher in comparison to $\mathrm{pH} 8,8$ for the same PAA concentration.

\section{Keywords}

Peracetic acid; cooling towers; slime; bacteria; biocorrosion. 


\section{Sumário}

1 Introdução 16

1.1 Relevância e Justificativa da Pesquisa 16

$\begin{array}{ll}1.2 \text { Objetivos } & 19\end{array}$

1.3 Estrutura do Trabalho 20

2 Revisão Bibliográfica 21

2.1 Considerações Iniciais 21

2.2 Tipos de Sistemas de Resfriamento 21

2.2.1 Sistemas Abertos Sem Recirculação de Água 21

2.2.2 Sistemas Fechados Com Recirculação de Água Fria 22

2.2.3 Sistemas Abertos Com Recirculação de Água 23

2.2.3.1 Torres de Resfriamento 24

2.2.3.2 Balanço Hídrico 26

2.2.3.3 Ciclos de Concentração 27

2.3 Principais Problemas em Sistemas de Resfriamento 27

2.4 Crescimento Microbiano em Sistemas Abertos com Recirculação de Água 28

2.4.1 Classificação e Microrganismos Presentes em Sistemas de Resfriamento 29

2.4.2 Bactérias em Sistemas de Resfriamento e Formação de Biofilme 32

2.4.3 Corrosão Microbiológica 34

2.4.4 Fatores que Influenciam o Crescimento Microbiano 39

2.4.5 Consequências do Crescimento Microbiano em Sistemas de Resfriamento 40

2.5 Tratamento de Águas de Resfriamento 41

2.5.1 Tratamento Biocida 41

2.5.1.1 Cloro e seus compostos 42

2.5.1.2 Ozônio 44

2.5.1.3 Peróxido de Hidrogênio $\quad 45$

2.5.1.4 Isotiazolonas $\quad 46$

2.5.1.5 Glutaraldeído 46

2.5.1.6 Sais Quaternários de amônio 46

2.5.1.7 Ácido Peracético 47

2.5.2 Resistência aos Biocidas $\quad 50$

2.6 Parâmetros Físico-químicos em Águas de Resfriamento 51

3 Metodologia Experimental e Materiais Utilizados 53 
3.1 Considerações Iniciais 53

3.2 Preparação das Amostras de Água de Resfriamento 53

3.3 Condições de Estudo $\quad 54$

3.4 Modo de Adição do Biocida 55

3.5 Preparação do Meio de Cultura 56

3.6 Preparação da Água Peptonada 56

3.7 Inoculações em Placas Petri 56

3.8 Contagem de Microrganismos $\quad 57$

3.9 Identificação das Estirpes Isoladas por Espectrometria de Massa do Tipo MALDI-TOF

4 Resultados e Discussão $\quad 59$

4.1 Considerações Iniciais $\quad 59$

4.2 Taxa de Decaimento de Ácido Peracético 59

4.3 Cinética de Decomposição do Ácido Peracético 62

4.4 Contagem Bacteriana Inicial das Amostras 64

4.5 Contagem Bacteriana após o Tratamento com Ácido Peracético 65

4.6 Consumo do Ácido Peracético ao longo dos Experimentos 72

4.7 Influência das Características da Água de Estudo na Ação Biocida do Ácido Peracético 78

4.8 Grupos de Microrganismos Presentes nas Amostras de Água $\quad 79$

5 Conclusões e Sugestões para Trabalhos Futuros 82

5.1 Conclusões 82

5.2 Sugestões Para Trabalhos Futuros 83

6 Referências Bibliográficas $\quad 84$

$\begin{array}{ll}\text { ANEXOS } & 91\end{array}$ 


\section{Lista de figuras}

Figura 2.1. Sistema de água de resfriamento aberto sem recircuçaõ de água (Fonte: MACHADO, 2004).

Figura 2.2. Sistema de água de resfriamento fechado (Fonte: MACHADO, 2004).

Figura 2.3. Sistema de água de resfriamento semi-aberto.

(Fonte: adaptado de SUZUKI, 1999).

Figura 2.4. Modelo clássico de torre de resfriamento de água, de tiragem induzida e fluxo em contracorrete (fonte: TROVATI, 2004).

Figura 2.5. Vazões em sistemas de resfriamento aberto com recirculação. (Fonte: adaptado de SUZUKI, 1999).

Figura 2.6. Etapas envolvidas na formação de biofilmes. (Fonte: MELO, 2012).

Figura 2.7. Reações de corrosão do aço carbono. (Fonte: SUZUKI, 1999).

Figura 2.8. Cloro gasoso, ácido hipocloroso e íon hipoclorito em função do pH. (Fonte: TROVATI, 2014).

Figura 3.1. Amostras da Água de Resfriamento.

Figura 4.1. Decomposição / consumo do ácido peracético para Dosagens iniciais de $1,0 \mathrm{mg} / \mathrm{L}$ e 2,0 mg/L ao longo de 1 hora quando este foi aplicado nas amostras de água de resfriamento com valor de $\mathrm{pH} 8,0$ e temperatura $32^{\circ} \mathrm{C}$.

Figura 4.2. Decomposição / consumo do ácido peracético para dosagens iniciais de 1,0 mg/L e 2,0 mg/L ao longo de 1 hora quando este foi aplicado nas amostras de água de resfriamento com valor de $\mathrm{pH} 8,8$ e temperatura $32^{\circ} \mathrm{C}$.

Figura 4.3. Modelo de primeira ordem de reação de decomposição para dosagem inicial de $1,0 \mathrm{mg} / \mathrm{L}$ de APA em $\mathrm{pH} 8,0$.

Figura 4.4. Modelo de primeira ordem de reação de decomposição para dosagem inicial de 2,0 mg/L de APA em pH 8,0.

Figura 4.5. Modelo de primeira ordem de reação de decomposição para dosagem inicial de $1,0 \mathrm{mg} / \mathrm{L}$ de APA em $\mathrm{pH} 8,8$. 
Figura 4.6. Modelo de primeira ordem de reação de decomposição para dosagem inicial de 2,0 mg/L de APA em $\mathrm{pH}$ 8,8.

Figura 4.7. Contagem bacteriana antes do tratamento com ácido peracético em cada experimento realizado.

Figura 4.8. Experimento 1 - Efeito do tratamento com 1,0 mg/L de ácido peracético $(\mathrm{pH} 8,0)$ ao longo dos 5 dias na microbiota presente na água de torre de resfriamento.

Figura 4.9. Experimento 2 - Efeito do tratamento com 2,0 mg/L de ácido peracético $(\mathrm{pH} \mathrm{8,0)}$ ao longo dos 5 dias na microbiota presente na água de torre de resfriamento.

Figura 4.10. Experimento 3 -Efeito do tratamento com 1,0 mg/L de ácido peracético $(\mathrm{pH} 8,8)$ ao longo dos 5 dias na microbiota presente na água de torre de resfriamento.

Figura 4.11. Experimento 4 -Efeito do tratamento com 2,0 mg/L de ácido peracético $(\mathrm{pH} 8,8)$ ao longo dos 5 dias na microbiota presente na água de torre de resfriamento.

Figura 4.12. Decaimento microbiano total ao final de cada dia ao longo do experimento com 1,0 mg/L de ácido peracético ( $\mathrm{pH} 8,0)$, com contagem microbiana inicial de 3,35 x 106 UFC/mL.

Figura 4.13. Decaimento microbiano total ao final de cada dia ao longo do experimento com 2,0 mg/L de ácido peracético $(\mathrm{pH} 8,0)$, com contagem microbiana inicial de 2,62 x 107 UFC/mL.

Figura 4.14. Decaimento microbiano total ao final de cada dia ao longo do experimento com 1,0 mg/L de ácido peracético $(\mathrm{pH} 8,8)$, com contagem microbiana inicial de 4,7 x 106 UFC/mL.

Figura 4.15. Decaimento microbiano total ao final de cada dia ao longo do experimento com 2,0 mg/L de ácido peracético ( $\mathrm{pH} 8,8)$, com contagem microbiana inicial de 1,5 x 106 UFC/mL.

Figura 4.16. Comparação da eficiência do ácido peracético nos quatro experimentos realizados, através do decaimento microbiano total ao final das campanhas de 5 dias.

Figura 4.17. Monitoramento da concentração de ácido peracético ao longo de 4 horas/dia nos 5 dias de experimento para dosagem de $1 \mathrm{mg} / \mathrm{L}(\mathrm{pH} 8,0)$. 
Figura 4.18. Monitoramento da concentração de ácido peracético ao longo de 4 horas/dia nos 5 dias de experimento para dosagem de $2 \mathrm{mg} / \mathrm{L}(\mathrm{pH} 8,0)$.

Figura 4.19. Monitoramento da concentração de ácido peracético ao longo de 4 horas/dia nos 5 dias de experimento para dosagem de $1 \mathrm{mg} / \mathrm{L}(\mathrm{pH} 8,8)$.

Figura 4.20. Monitoramento da concentração de ácido peracético ao longo de 4 horas/dia nos 5 dias de experimento para dosagem de $2 \mathrm{mg} / \mathrm{L}(\mathrm{pH} 8,8)$.

Figura 4.21. Concentração de ácido acético ao longo dos 5 dias para dosagens iniciais de ácido peracético de $1 \mathrm{mg} / \mathrm{L}$ e $2 \mathrm{mg} / \mathrm{L}$ ( $\mathrm{pH} \mathrm{8,0)}$ ). Figura 4.22. Concentração de ácido acético ao longo dos 5 dias para dosagens iniciais de ácido peracético de $1 \mathrm{mg} / \mathrm{L} \mathrm{e} 2 \mathrm{mg} / \mathrm{L}$ ( $\mathrm{pH} 8,8$ ). 


\section{Lista de tabelas}

Tabela 2.1. Porcentagem de água arrastada em relação à vazão de circulação - adaptado de Dantas (1998).

Tabela 2.2: Fontes de energia e nutrientes de microrganismos comuns em sistemas de resfriamento - adaptado de Suzuki (1999).

Tabela 2.3: Principais microrganismos nos sistemas de resfriamento adaptado de Xu (2012).

Tabela 2.4: Qualidade de água de reposição para uso em sistemas de resfriamento com circuitos semi-abertos (Environmental Protection Agency apud Machado, 2004). 52

Tabela 3.1: Caracterização da água diluída.

Tabela 3.2: Condições da água de resfriamento para análise bacteriológica.

Tabela 4.1: Concentração de ácido acético ao final dos experimentos. 76 Tabela 4.2: Espécies de bactérias presentes na água antes e depois do tratamento com ácido peracético. 


\section{Lista de siglas e abreviações}

APA - Ácido Peracético

COT - Carbono Orgânico Total

DBO - Demanda Bioquímica de Oxigênio

DQO - Demanda Química de Oxigênio

STD - Sólidos Totais Dissolvidos

STS - Sólidos Totais Suspensos

HClO - Ácido Hipocloroso

$\mathrm{ClO}^{-}$- Íon Hipoclorito

UFC - Unidade Formadora de Colônia

BRS - Bactérias Redutoras de Sulfato

AA - Ácido Acético 


\section{Introdução}

\section{1}

\section{Relevância e Justificativa da Pesquisa}

Grande parte dos processos industriais, em segmentos distintos, gera calor em suas atividades. Pode-se citar como exemplos: Indústrias siderúrgicas, metalúrgicas, alimentícias, petrolíferas e químicas. Além disso, sistemas de ar condicionado central em edificações. Nessas operações, torna-se necessária a remoção da carga térmica gerada nos processos ou ambientes internos, através de sistemas de resfriamento.

Na maioria dos casos, a água é utilizada como agente de resfriamento e sua qualidade é de extrema relevância a fim de evitar os problemas que aparecem em tais sistemas, dentre eles:

- Processos corrosivos;

- Incrustações;

- Formação de depósitos;

- Desenvolvimento microbiológico.

Com a crescente preocupação com o meio ambiente, a redução do consumo de água e energia vem sendo trabalhada com prioridade. Com isso, sistemas abertos com recirculação de água são comuns nos diversos setores industriais. Esse tipo de sistema possui como princípio a reutilização de água, onde este fluido ao sair dos trocadores de calor é resfriado em equipamentos, em sua maioria, torres de resfriamento, e então é reutilizado nos processos industriais. Grande parte das torres de resfriamento possuem sistemas de ventiladores, onde o ar é sugado para o interior do equipamento, e ao entrar em contato com a água, esta é resfriada principalmente devido ao calor latente de evaporação, ocasionando aumento na concentração de sais dissolvidos no sistema, sendo necessário realizar purgas (drenar certa quantidade de água) e repor água nova no sistema. Esta água, denominada água de 
reposição, além da própria água circulante, se não tratada e sem qualidade, acelera processos corrosivos, incrustantes e microbiológicos.

O controle do desenvolvimento microbiológico é o objeto de estudo no presente trabalho. Os microrganismos podem entrar nos sistemas por diferentes meios: através da água de reposição, vazamentos de processo ou pelo ar. Além disso, as bacias das torres de resfriamento estão expostas à luz solar, propiciando o crescimento de algas. A matéria orgânica produzida por elas e as células mortas podem servir de nutrientes que auxiliam na multiplicação dos microrganismos neste ambiente. Ao mesmo tempo, o $\mathrm{pH}$ e temperatura da água de resfriamento propiciam condições ótimas para o crescimento de determinados grupos microbianos. A maior preocupação em sistemas de resfriamento é o desenvolvimento de bactérias sésseis, pois as mesmas são responsáveis pela formação de biofilme, onde em certas condições ambientais, os microrganismos podem aderir às superfícies e produzir uma matriz exopolimérica, dentro dos quais as células individuais metabolizam e replicam. Como consequência, o desenvolvimento do biofilme pode dificultar os processos de resfriamento, promover a corrosão induzida microbiologicamente (CIM), bem como bloqueio de tubulações, resistência à transferência de calor, levando a perdas econômicas substanciais (DI GREGORIO et al., 2017).

Um dos métodos empregados para o controle da carga microbiana em tais sistemas é através do tratamento químico, em que compostos tóxicos são adicionados nas águas de resfriamento, a fim de atuar de diversas formas inibindo o crescimento e a atividade metabólica microbiana, controlando ou eliminando os microrganismos responsáveis pela formação do biofilme (PERES, 2006). Estes produtos são denominados biocidas.

Classifica-se dois tipos de biocidas: Os oxidantes e não oxidantes. Os primeiros agem através da oxidação da matéria orgânica presente nos seres vivos, destruindo suas estruturas vitais e causando a morte dos mesmos. Entre os principais representantes desta classe, pode-se mencionar: Cloro e seus compostos, compostos de bromo, peróxidos e ozônio. Já os segundos, apresentam mecanismos de ação peculiares e específicos para o controle dos microrganismos, e dentre eles estão incluídos: Sais quaternários de amônio, glutaraldeído, isotiazolonas (TROVATI, 2004).

$\mathrm{O}$ biocida mais utilizado pelas indústrias é o cloro e seus derivados, devido à comprovada eficiência deste produto no combate microbiano e ao seu custo 
relativamente baixo. No tratamento de águas, a sua aplicação se baseia principalmente na formação do ácido hipocloroso $(\mathrm{HClO})$ e íon hipoclorito $\left(\mathrm{ClO}^{-}\right)$, sendo o primeiro o maior responsável pela ação oxidante do composto. Contudo, o cloro apresenta algumas desvantagens: Na presença de matéria orgânica natural ou sintética em água, o cloro reage formando compostos organoclorados e cloraminas (a partir de amônia), podendo formar subprodutos como trialometanos e clorofenóis, considerados tóxicos e potencialmente carcinogênicos (DANIEL et al., 2000). Além disso, o cloro pode acelerar processos corrosivos nas superfícies metálicas presentes nos sistemas de resfriamento.

Visto isso, biocidas alternativos vêm sendo estudados. De forma a garantir que o biocida testado seja competitivo com o cloro, alguns fatores devem ser levados em consideração:

- Custo: Como o cloro é vantajoso economicamente, deve-se buscar um biocida que apresente custo de tratamento similar ou inferior ao cloro;

- Concentração do biocida: O produto deve ser eficiente em baixas concentrações, para que sua utilização se torne viável;

- Estudo da formação de subprodutos: Para justificar a sua utilização em detrimento ao cloro, o biocida não deve gerar subprodutos tóxicos;

- Potencial corrosivo: O potencial corrosivo do biocida também deve ser estudado, visto que processos corrosivos nos sistemas de resfriamento podem ocasionar aumento nos custos de manutenção, redução da vida útil dos trocadores de calor e vazamentos de processo.

O objetivo deste trabalho é testar a eficiência do APA como biocida. Sabese que este produto é um desinfetante consagrado e já é utilizado em diversos ramos industriais. Atua amplamente em diferentes tipos de microrganismos e é eficiente em ampla faixa de pH e temperatura (DANIEL et al., 2000).

Estudos anteriores demonstraram que o APA não é dependente de longo tempo de contato para uma ação eficiente nos microrganismos. Em 5 minutos após a sua aplicação, já se observa o seu efeito desinfetante. Além disso, existem relatos que o APA não forma subprodutos com atividade mutagênica e/ou carcinogênica (CREBELLI et al., 2004). 
Quanto ao efeito biocida do APA, ele já foi estudado com resultados satisfatórios para diversos fins, por exemplo: $\mathrm{Na}$ esterilização de equipamentos médicos e odontológicos, no tratamento de esgoto e efluente e como desinfetante na indústria alimentícia (CERETTA, 2008; BALDRY et al., 1995; CAVALINNI et al., 2012; ROSSI et al., 2007).

O custo do APA é elevado em comparação ao cloro, porém, se menores consumos do produto em relação a compostos clorados forem suficientes no controle microbiológico, pode ser que seja viável e vantajoso economicamente.

Diante do exposto acima, a pesquisa da utilização do APA como biocida em tratamento de águas de resfriamento se justifica. Cabe ressaltar que a maioria dos estudos já realizados sobre a aplicação do APA estão ligados a tratamento de esgoto sanitário. Portanto, como as condições dos sistemas de resfriamento são diferentes, o que pode afetar a eficiência do biocida, uma investigação mais detalhada da aplicação deste composto nesse tipo de sistema torna-se interessante.

\section{2}

\section{Objetivos}

O objetivo principal deste trabalho é analisar a eficiência do emprego do APA como biocida alternativo ao cloro em uma amostra de água de resfriamento de uma indústria química.

De acordo com o principal objetivo, para chegar ao resultado final, tem-se os seguintes objetivos específicos:

- Quantificar e caracterizar a carga microbiana presente na água de resfriamento sem a adição do biocida e após a adição do produto em diferentes concentrações: 1,0 mg/L e 2,0 mg/L, e valores de pH: 8,0 e 8,8;

- Acompanhar o efeito biocida sobre a carga microbiana das amostras de água de resfriamento em campanhas de 5 dias de duração para cada condição de estudo. 


\section{3}

\section{Estrutura do Trabalho}

Este trabalho é dividido em cinco capítulos, começando com este capítulo introdutório. Em seguida, no capítulo 2, é apresentada a revisão bibliográfica sobre os tipos de sistemas de resfriamento, os microrganismos que geralmente encontramse nas águas de resfriamento, os fatores que influenciam seu crescimento, os processos corrosivos associados ao crescimento microbiano, as consequências deste problema nos sistemas de resfriamento, os principais biocidas utilizados no tratamento de águas, bem como suas vantagens e desvantagens.

O capítulo 3 apresenta a metodologia experimental realizada nesta pesquisa, descrevendo os materiais e equipamentos utilizados e os procedimentos.

O capítulo 4 descreve os resultados obtidos na etapa experimental, bem como a discussão dos mesmos.

Por último, o capítulo 5 apresenta as conclusões e recomendações para futuros trabalhos 


\section{2. \\ Revisão Bibliográfica}

\section{1}

\section{Considerações Iniciais}

No presente capítulo, é apresentada a revisão bibliográfica encontrada sobre o tema. São expostos os tipos de sistemas de resfriamento, os principais problemas que podem ocorrer em tais sistemas, os microrganismos mais comuns nas águas de resfriamento e as consequências da sua presença, os biocidas utilizados para tratamento, bem como suas vantagens e desvantagens e as características do APA e suas aplicações nos dias atuais.

\section{2}

\section{Tipos de Sistemas de Resfriamento}

Diversos setores industriais geram calor em suas atividades e por este motivo em diversos casos, é necessário um sistema de resfriamento, onde utiliza-se um fluido, normalmente a água, a fim de absorver e conduzir calor de um equipamento. $\mathrm{O}$ processo se aplica às mais variadas indústrias, tais como: Petrolíferas, petroquímicas, químicas, siderúrgicas, frio industrial e ambiental. Aplica-se também na refrigeração de camisas e cabeçotes de motores à explosão, compressores, calandras, condensadores de vapor (GENTIL, 1996).

Existem três tipos de sistemas de resfriamento: Sistemas abertos sem recirculação de água, sistemas fechados com recirculação de água e sistemas abertos com recirculação de água. Tais sistemas são descritos nos itens a seguir.

\subsection{1}

\section{Sistemas Abertos Sem Recirculação de Água}

Esse sistema também é denominado de sistema de uma só passagem. A água, após passar pelos equipamentos de troca térmica, é descarregada diretamente 
no corpo receptor. Como não há recirculação, esse sistema só é empregado em locais com grande disponibilidade de água. Nesse tipo de sistema, devido à grande quantidade de água utilizada, um tratamento químico e controle da qualidade da água se torna muito caro e inviável. A figura 2.1 ilustra esse tipo de sistema.

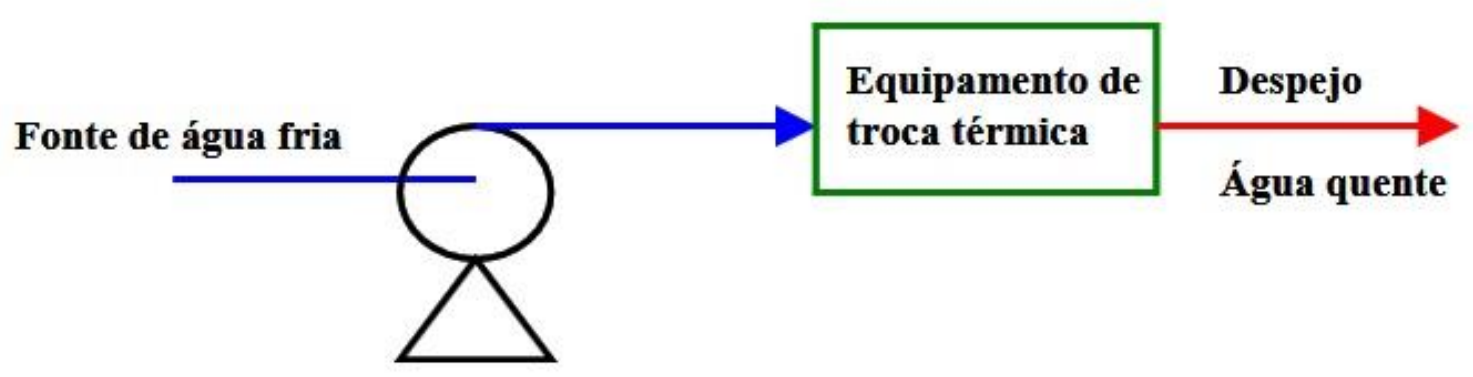

Figura 2.1: Sistema de água de resfriamento aberto sem recirculação de água. (Fonte:

MACHADO, 2004).

\section{2 .2}

\section{Sistemas Fechados Com Recirculação de Água Fria}

No sistema fechado, a água que é aquecida por passagem através de trocadores de calor, é resfriada em um refrigerador secundário. A água é então recirculada e reutilizada no processo. As perdas de água são baixas nesse tipo de sistema e não ocorre concentração de sólidos dissolvidos. Pode-se citar como exemplos que utilizam esse tipo de sistema motores a combustão interna e aparelhos de ar condicionado. A figura 2.2 demonstra o funcionamento de um sistema de resfriamento fechado.

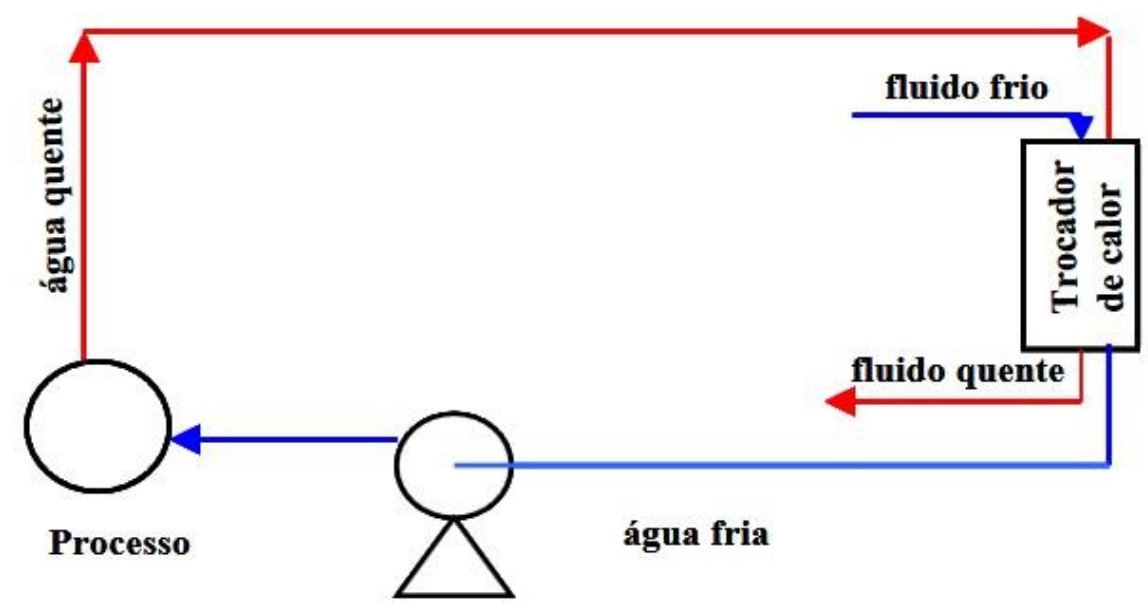

Figura 2.2: Sistema de água de resfriamento fechado. (Fonte: MACHADO, 2004). 


\subsection{3}

\section{Sistemas Abertos Com Recirculação de Água}

Também conhecidos como sistemas semi-abertos, são utilizados com a finalidade primordial de economizar água e possibilitar um tratamento adequado contra corrosão, incrustações e proliferação de microrganismos (GENTIL, 1996). No sistema semi-aberto, a água aquecida nos equipamentos de troca térmica é resfriada na maioria dos casos em uma torre de resfriamento. A água é então recirculada e reutilizada no processo, conforme demonstrado na figura 2.3. Nesse tipo de sistema, há perdas no processo, e consequentemente, concentração de sólidos dissolvidos e outras espécies tais como o cloreto, o que aumenta o risco de corrosão, incrustação, depósitos e crescimento microbiológico.

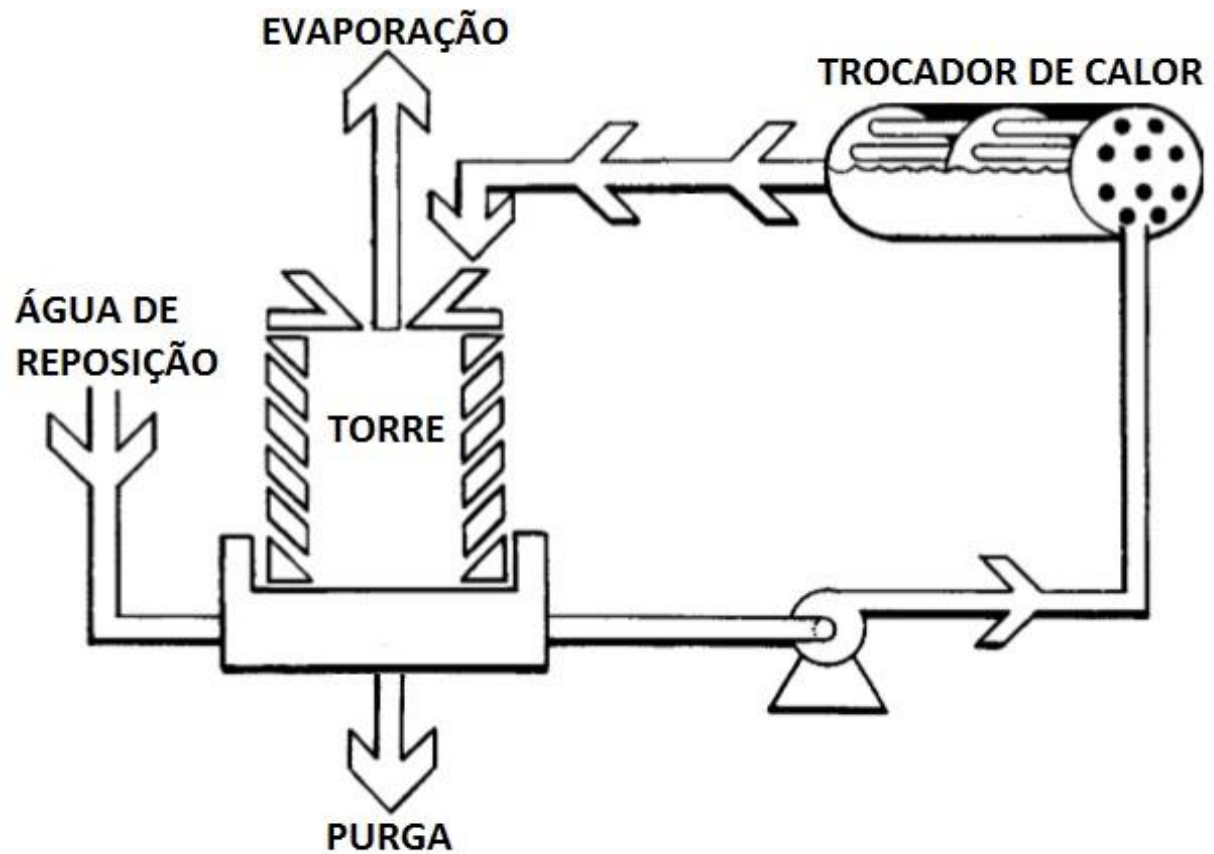

Figura 2.3: Sistema de água de resfriamento semi-aberto. (Fonte: adaptado de SUZUKI, 1999).

Nos itens a seguir, são expostos alguns conceitos importantes para melhor entendimento desse tipo de sistema. 


\subsubsection{1}

\section{Torres de Resfriamento}

Este equipamento tem a função de rejeitar calor, liberando energia térmica para a atmosfera através do arrefecimento de uma corrente de água aquecida inicialmente a uma determinada temperatura até uma temperatura menor, através da troca de calor dessa água com uma corrente de ar (MACHADO, 2004).

$\mathrm{Na}$ maioria dos sistemas de torre de resfriamento, a água quente que sai dos trocadores de calor é bombeada para o topo da torre onde é distribuída por tubos ou calhas sob o material de enchimento interno, chamado de colméia. A colméia permite que água aquecida seja espalhada de forma uniforme por toda área transversal da torre. $\mathrm{O}$ ventilador da torre puxa o ar através da água que está caindo sobre a colméia para provocar a evaporação. $\mathrm{O}$ ar pode ser puxado, pelo ventilador, através das venezianas em um fluxo contrário, transversal ou paralelo ao fluxo da água aquecida que está caindo na torre. Quanto maior for a mistura entre o ar e a água, mais eficiente será o resfriamento (PERES, 2006).

O resfriamento da água nas torres ocorre principalmente através da transferência de calor latente pela evaporação de certa quantidade de água, onde há uma diferença de concentração entre a água (fase líquida) e a água presente no ar (fase vapor), proporcionando uma força motriz que faz com que a água no estado líquido tenha tendência a equilibrar a concentração com a fase gasosa, necessitando de energia, que é obtida na forma de calor da água que permanece na fase líquida, resultando no resfriamento desta última (TROVATI, 2004). O restante do calor perdido ocorre quando a temperatura de bulbo úmido, que representa o conteúdo de calor no ar atmosférico, é mais baixa do que a temperatura da água e o calor é transferido da água para o ar e se denomina calor sensível (DANTAS, 1988). Ainda de acordo com Dantas (1988), o valor do calor latente nas torres representa 75 a $90 \%$ do calor perdido, enquanto o calor sensível representa 10 a $25 \%$ da transferência de calor da água em uma torre de resfriamento.

Após o resfriamento, a água da bacia da torre é bombeada de volta ao processo industrial para absorver mais calor. 
Pode-se classificar as torres de resfriamento em dois tipos: Tiragem natural e tiragem mecânica. Segundo a NBR 6111:2013, na torre de tiragem natural a movimentação do ar é obtida por meio da diferença de densidade entre o ar no interior dela e o ar no exterior. Já na torre de tiragem mecânica a movimentação do ar é obtida por meio de um ou mais ventiladores. Esta última pode ser de tiragem forçada, ou seja, com um ou mais ventiladores localizados na entrada de ar, ou de tiragem induzida, com um ou mais ventiladores localizados na saída de ar. Além disso, de acordo com a direção do ar e da água, são classificadas em contra fluxo, onde o ar se move verticalmente para cima através do enchimento da torre, contra a queda d'água, e fluxo cruzado, em que o ar flui horizontalmente através da queda da água. Na figura 2.4, pode-se observar o modelo clássico de torre de resfriamento de água, de tiragem induzida e fluxo em contracorrente.

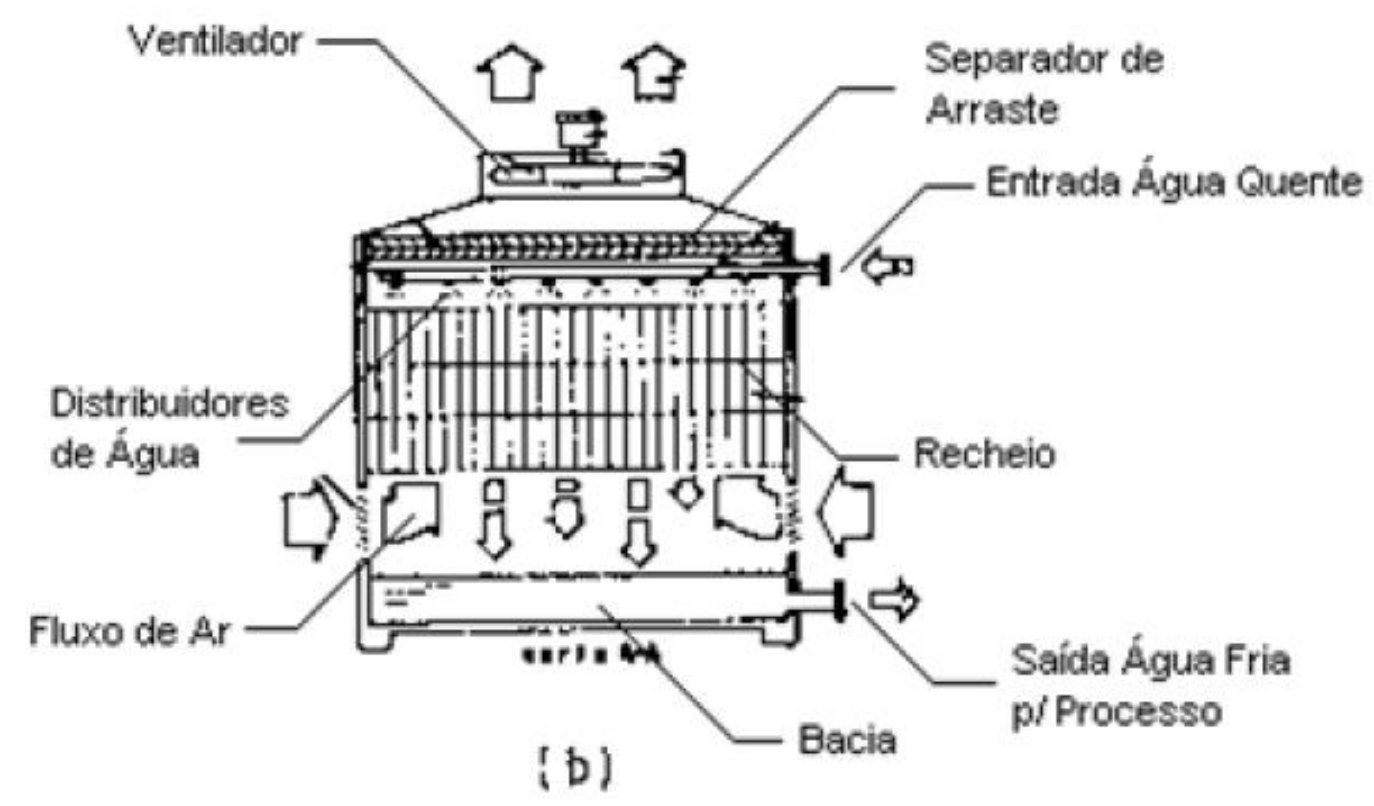

Figura 2.4: Modelo clássico de torre de resfriamento de água, de tiragem induzida e fluxo em contracorrente (Fonte: TROVATI,2004).

Nesse tipo de sistema, além da perda de água pela evaporação, também ocorrem perdas por arraste, devido as gotículas de água do sistema que são arrastadas com o ar. Seu valor depende do projeto e da condição de operação da 
torre de resfriamento. A tabela 2.1 mostra a porcentagem da água arrastada em relação a vazão de circulação nos diferentes tipos de torre de resfriamento.

Tabela 2.1: Porcentagem de água arrastada em relação à vazão de circulação - adaptado
\begin{tabular}{ccc}
\hline \multicolumn{3}{c}{ Dantas (1998). } \\
\hline Tipo de Torre & \% de Arraste (Média) & Faixa \% de Arraste \\
\hline Tiragem Induzida & 0,2 & $0,05-0,3$ \\
Tiragem Forçada & 0,2 & $0,05-0,3$ \\
Tiragem Natural & 0,5 & $0,3-1,0$ \\
\hline
\end{tabular}

Devido às perdas do sistema, ocorre a concentração de sólidos dissolvidos. Portanto, é necessário drenar continuamente certa quantidade de água da bacia da torre de resfriamento, de forma a reduzir o acúmulo de contaminantes deletérios na água circulante (PERES, 2006), este processo é denominado purga.

De modo a repor a água perdida no sistema aberto de recirculação de água, adiciona-se água nova na torre, denominada água de reposição. Esta deve passar por tratamento químico adequado, através da utilização de insumos químicos uma vez que sua qualidade é de extrema importância para evitar problemas de corrosão, incrustação, depósitos e crescimento microbiano.

\subsubsection{2}

\section{Balanço Hídrico}

Nos sistemas de água de resfriamento, o volume total do sistema é constante nas condições normais de operação (SUZUKI, 1999). Portanto, a quantidade de água de reposição é equivalente ao volume total de água perdida no sistema por evaporação, arraste e purga.A figura 2.5 esquematiza essas variantes em sistemas de resfriamento aberto com recirculação de água. 


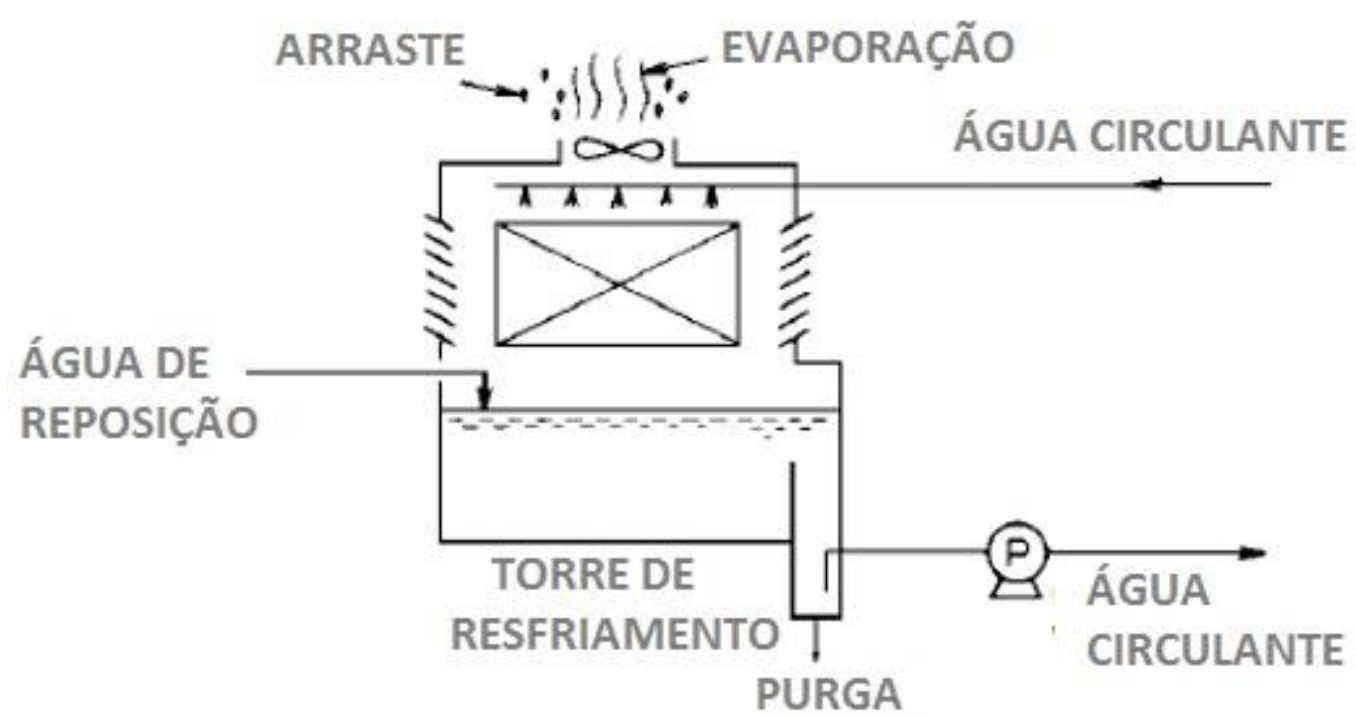

Figura 2.5: Vazões em sistemas de resfriamento aberto com recirculação. (Fonte: adaptado de SUZUKI, 1999).

\subsubsection{3}

\section{Ciclos de Concentração}

O número de ciclos indica a relação de concentração de sólidos dissolvidos na água circulante àquela da água de reposição. Um aumento no número de ciclos resulta em uma redução do volume de purga, e consequentemente no consumo de produtos químicos e o volume de água de reposição. De acordo com Suzuki (1999) os sistemas de água de refrigeração são geralmente operados com o número de ciclos inferior a 5 .

\subsection{Principais Problemas em Sistemas de Resfriamento}

As águas de resfriamento se não possuírem níveis aceitáveis de qualidade e não tratadas de forma correta podem desencadear sérios problemas que comprometem o processo de resfriamento. Entre eles, os principais são:

- Corrosão: Caso o meio seja agressivo, os materiais metálicos ficam sujeitos à corrosão, que é a deterioração de material, normalmente metálico, por 
ação química ou eletroquímica do meio ambiente, representando alterações prejudiciais indesejáveis sofridas pelo material (DANTAS, 1988);

- Depósitos e incrustações: Nos sistemas de resfriamento podem ocorrer depósitos indesejáveis de sais na superfície metálica de equipamentos de troca térmica, acarretando redução na taxa de transferência de calor, paralização do processo produtivo para realização de manutenção nos trocadores de calor, redução de vida útil dos equipamentos. Por ser um sistema evaporativo, o sistema aberto de recirculação de água gera uma concentração de sais no sistema, portanto, o controle de salinidade deve ser realizado de forma correta (VEIGA, 2010).

- Crescimento Microbiano: O crescimento de microrganismos nesses sistemas também pode acarretar sérios problemas na eficiência do processo de resfriamento. Os sistemas abertos com recirculação de água são os mais comuns a desenvolver esse inconveniente, visto que os microrganismos podem entrar no sistema através do ar, da água de reposição ou de vazamentos do processo (SUZUKI, 2009). Essa adversidade é objeto deste estudo e é desenvolvido com mais detalhes nos itens subsequentes.

\section{4}

\section{Crescimento Microbiano em Sistemas Abertos com Recirculação de Água}

Os sistemas de resfriamento são ambientes propícios para o crescimento de microrganismos, uma vez que a água é aerada, as bacias das torres de resfriamento estão expostas à luz solar e os valores de $\mathrm{pH}$ e a temperatura desses sistemas encontram-se em condições favoráveis para o desenvolvimento microbiano (GENTIL, 1996).

Nos itens a seguir, são observados os tipos de microrganismos presentes nos sistemas de resfriamento e os fatores que influenciam o seu crescimento, e as consequências geradas pelo crescimento microbiano. 


\subsection{1 \\ Classificação e Microrganismos Presentes em Sistemas de Resfriamento}

Os microrganismos geralmente utilizam o carbono como fonte de energia para o seu metabolismo. Com relação à necessidade de carbono, os microrganismos podem ser divididos em autotróficos ou heterotróficos. Os autotróficos utilizam o dióxido de carbono como fonte de carbono e estes podem ser quimiosintéticos (obtém energia da oxidação de compostos inorgânicos) ou fotossintéticos (obtém energia da radiação solar). Já os heterotróficos utilizam matéria orgânica como fonte de carbono.

Além disso, os microrganismos podem ser classificados de acordo com a necessidade de oxigênio. Os seres aeróbios necessitam de oxigênio para seu metabolismo, os anaeróbios se desenvolvem em ambientes sem oxigênio e os facultativos crescem em ambientes tanto aeróbios como anaeróbios (VIDELA, 2003).

A tabela 2.2 mostra os tipos de microrganismos comuns nos sistemas de resfriamento, bem como a fonte de energia e os nutrientes requeridos para seu crescimento.

Tabela 2.2: Fontes de energia e nutrientes de microrganismos comuns em sistemas de resfriamento adaptado de Suzuki (1999).

\begin{tabular}{ccc}
\hline Tipo de Microrganismo & Fonte de Energia & Nutriente \\
\hline $\begin{array}{c}\text { Bactérias aeróbias e anaeróbias em } \\
\text { geral, fungos }\end{array}$ & Oxidação de substâncias orgânicas & Substâncias orgânicas \\
$\begin{array}{c}\text { Bactérias oxidantes de ferro, } \\
\text { bactérias oxidantes de enxofre e } \\
\text { bactérias nitrificantes }\end{array}$ & $\begin{array}{c}\text { Oxidação de substâncias } \\
\text { inorgânicas }\end{array}$ & Substâncias inorgânicas \\
Algas & Energia Solar & $\begin{array}{c}\text { Substâncias inorgânicas } \\
\text { (principalmente carbonato) }\end{array}$ \\
\hline
\end{tabular}

Geralmente, as bactérias aeróbias predominam em sistemas abertos de recirculação de água, no entanto, bactérias anaeróbias podem crescer sob depósitos de microrganismos aeróbios. As algas crescem em locais expostos à luz solar, como nas bacias das torres de resfriamento. Já os fungos necessitam de grande quantidade 
de matéria orgânica para se desenvolverem e por isso são menos comuns que os microrganismos citados anteriormente.

Na tabela 2.3 são pontuados os principais gêneros de microrganismos presentes nos sistemas de resfriamento, bem com as faixas ótimas de temperatura e $\mathrm{pH}$ para seu crescimento e os problemas verificados em tais sistemas devido ao desenvolvimento destes. 
Tabela 2.3: Principais Microrganismos nos Sistemas de Resfriamento - adaptado de Xu (2012).

\begin{tabular}{|c|c|c|c|c|}
\hline $\begin{array}{c}\text { Tipo de } \\
\text { Microrganismo }\end{array}$ & Microrganismo & $\begin{array}{c}\text { Temperatura } \\
\left({ }^{\circ} \mathrm{C}\right)\end{array}$ & pH & Consequências \\
\hline Bactéria & $\begin{array}{c}\text { Bactérias } \\
\text { aeróbicas } \\
\text { envolvidas por } \\
\text { cápsula }\end{array}$ & $20-40$ & $4,0-8,0$ & $\begin{array}{l}\text { Formação de } \\
\text { Biofilme }\end{array}$ \\
\hline Bactéria & $\begin{array}{c}\text { Bactérias } \\
\text { oxidantes de } \\
\text { enxofre }\end{array}$ & $10-37$ & $0,6-7,8$ & Corrosão \\
\hline Bactéria & $\begin{array}{l}\text { Bactérias } \\
\text { redutoras de } \\
\text { sulfato }\end{array}$ & $0-70$ & $5,5-9,0$ & $\begin{array}{l}\text { Produz sulfato } \\
\text { de hidrogênio, } \\
\text { causando } \\
\text { corrosão }\end{array}$ \\
\hline Bactéria & $\begin{array}{c}\text { Bactérias } \\
\text { oxidantes de } \\
\text { ferro }\end{array}$ & $0-40$ & $6,0-9,5$ & $\begin{array}{l}\text { Formação de } \\
\text { hidróxido de } \\
\text { ferro ao redor } \\
\text { da casca } \\
\text { protetora da } \\
\text { célula }\end{array}$ \\
\hline Fungo & Bolores & $0-38$ & $2,0-8,0$ & $\begin{array}{l}\text { Formação de } \\
\text { biofilme }\end{array}$ \\
\hline Fungo & Levedura & $0-38$ & $2,0-8,0$ & $\begin{array}{l}\text { Bloqueio, } \\
\text { redução da } \\
\text { taxa de } \\
\text { transferência } \\
\text { de calor }\end{array}$ \\
\hline Alga & Chorella & $30-35$ & $5,5-8,9$ & $\begin{array}{l}\text { Bloqueio, } \\
\text { redução da } \\
\text { taxa de } \\
\text { transferência } \\
\text { de calor }\end{array}$ \\
\hline Alga & Cianobactérias & $35-40$ & $6,0-8,9$ & $\begin{array}{l}\text { Bloqueio, } \\
\text { redução da } \\
\text { taxa de } \\
\text { transferência } \\
\text { de calor }\end{array}$ \\
\hline Alga & Diatomáceas & $17-36$ & $5,5-8,9$ & $\begin{array}{l}\text { Bloqueio, } \\
\text { redução da } \\
\text { taxa de } \\
\text { transferência } \\
\text { de calor }\end{array}$ \\
\hline
\end{tabular}

Como observado na tabela 2.3, a maioria dos microrganismos se desenvolve em ampla faixa de temperatura e $\mathrm{pH}$, e como nos sistemas de resfriamento o $\mathrm{pH}$ 
costuma apresentar valores entre 7 e 9 , a temperatura da água entre $20{ }^{\circ} \mathrm{C} \mathrm{a} 40{ }^{\circ} \mathrm{C}$, além de ser fontes de nutrientes, esses sistemas são propícios para o desenvolvimento microbiano (XU, 2012).

\subsection{2}

\section{Bactérias em Sistemas de Resfriamento e Formação de Biofilme}

As bactérias presentes nos sistemas de resfriamento podem ser divididas nas formas planctônicas e sésseis, esta última sendo responsável pela formação do biofilme (TANJI et al., 2007). Segundo Dantas (1988), as bactérias sésseis são envolvidas por uma cápsula gelatinosa, basicamente formada de polissacarídeos e este material possui alta adesividade a diferentes tipos de materiais, enquanto as planctônicas possuem alta mobilidade e permanecem flutuando nas águas de resfriamento.

As bactérias sésseis são mais comuns nesses sistemas e formam biofilme nas superfícies metálicas através da elaboração de polímeros extracelulares (EPS) que envolvem e aglutinam as células protegendo-as contra as condições adversas do meio corrosivo. Após a fixação destas bactérias na superfície metálica em combinação com o meio que contém nutrientes, há o crescimento e a multiplicação das bactérias (MAINER, 2007).

Das bactérias existentes em águas de resfriamento, aproximadamente $70 \%$ pertencem aos gêneros Pseudomonas e Aerobacter, e o biofilme está fortemente associado às primeiras (DANTAS, 1998), elas são aeróbicas, gram-negativas, conhecidas como pioneiras no processo de formação dos biofilmes, por ter motilidade. Seus processos metabólicos produzem EPS, no qual a produção é acelerada na presença de oxigênio. A produção de EPS promove um gradiente de concentração de oxigênio, favorecendo o crescimento de bactérias redutoras de sulfato (SILVA, 2013).

O processo de formação de biofilme é complexo e compreende uma sequência de etapas (PIPPO et al, 2018), dentre elas:

I - Adesão reversível - Transporte de células livres do meio líquido para uma superfície sólida e sua subsequente fixação. 
II - Adesão irreversível - Crescimento e divisão das células fixadas à custa de nutrientes provenientes do líquido circulante, conjuntamente com a produção de metabólitos e excreção, enfatizando-se os EPS.

III - Fixação de outros microrganismos flutuantes, contribuindo para o espessamento do biofilme.

IV - Liberação de material celular por dois mecanismos diferentes: perda por erosão (perda de células individuais) e liberação de células devido à velocidade de fluxo, morte celular, etc.

A figura 2.6 compreende as etapas descritas acima.

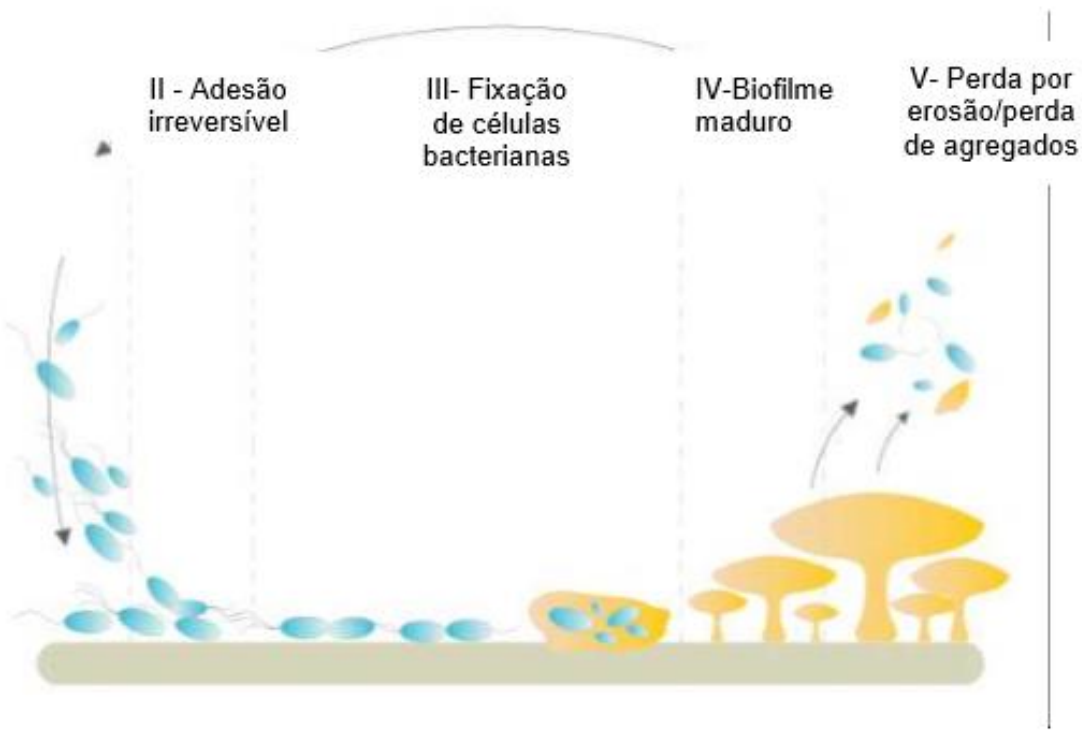

Figura 2.6: Etapas envolvidas na formação de biofilmes. (Fonte: MELO, 2012).

Os biofilmes possuem caráter protetor aos microrganismos, tornando, assim, uma fonte resistente de contaminação à ação de agentes químicos e físicos, como sanitizantes empregados nos processos de higienização (SIMÕES et al., 2010; PARK et al., 2012).

De acordo com Suzuki (1999), como o biofilme é essencialmente causado pelo crescimento bacteriano nos sistemas de resfriamento, quanto maior o número de bactérias, maior será a frequência dos problemas relacionados ao biofilme. Portanto, o ideal é que o número destes microrganismos nos sistemas seja inferior à $10^{3} \mathrm{UFC} / \mathrm{mL}$, mas é aceitável valores na ordem de grandeza até $10^{4} \mathrm{UFC} / \mathrm{mL}$, onde UFC (unidade formadora de colônia) é a unidade utilizada para estimar essa carga microbiana. Segundo a Standard Methods For The Examination of Water and Wastewater (1998) as colônias podem surgir de pares, cadeias, aglomerados ou de 
uma única célula, os quais estão incluídos no termo "Unidades Formadoras de Colônia".

A presença de biofilme em sistemas de água de resfriamento também pode representar um risco à saúde pública devido à presença de patógenos. Os biofilmes podem favorecer a presença, sobrevivência e proliferação de bactérias patogênicas termotolerantes, especialmente Legionella pneumophila, responsáveis por cerca de 90\% dos casos mundiais de doença do legionário, caso grave de pneumonia (WÉRY et al., 2008; WALSER et al., 2014; PEREIRA et al., 2017; DI PIPPO et al., 2018). As torres de resfriamento são fontes propícias ao desenvolvimento de Legionellas e deve-se adotar medidas de modo a prevenir e controlar a sua proliferação.

A seguir os processos corrosivos associados aos microrganismos são apresentados com mais detalhes.

\subsection{3}

\section{Corrosão Microbiológica}

Gentil (1996) define a corrosão como a deterioração de um material, geralmente metálico, por ação química ou eletroquímica do meio ambiente aliada ou não a esforços mecânicos. $\mathrm{O}$ autor ainda ressalta que a deterioração causada pela interação físico-química entre o material e seu meio operacional representa alterações prejudiciais indesejáveis, sofridas pelo material, tais como desgaste, variações químicas ou solidificações estruturais, tornando-o inadequado para o uso.

A corrosão em sistemas de resfriamento costuma ser de natureza eletroquímica, onde há uma reação química com envolvimento de elétrons. Neste tipo de corrosão tem-se um pólo negativo (catodo) e um pólo positivo (anodo), em que uma corrente de elétrons flui no sentido anodo-catodo, ocasionando a oxidação do anodo, ou seja, a corrosão. O fluxo de elétrons depende de um meio de contato entre os pólos, o eletrólito, sendo no caso dos sistemas de resfriamento, a água (VEIGA, 2010).

Os sistemas de resfriamento são propícios ao crescimento de bactérias por diversos fatores, principalmente as sésseis. Essas bactérias são determinantes no desenvolvimento de processos corrosivos e é motivo de grande preocupação nas indústrias. Este tipo de corrosão, ocasionada por microrganismos é denominada corrosão microbiologicamente influenciada (CIM). A CIM se processa sob a 
influência principalmente de bactérias, embora também existam exemplos de corrosão atribuídos a fungos e algas.

Segundo Mainer (2007), a CIM tem sido alertada desde 1910 como grande responsável na deterioração de materiais metálicos. Este tipo de corrosão tem sido encontrado com frequência nos sistemas de resfriamento, nos trocadores e dutos que utilizam água do mar, nos tanques de petróleo, na recuperação secundária de petróleo, nas unidades de tratamento de efluentes, nas tubulações enterradas. Um dos mecanismos aceitos é a formação de um biofilme na superfície metálica por meio de bactérias sésseis, que através da elaboração de polímeros extracelulares envolvem e aglutinam as células protegendo-as contra as condições adversas do meio corrosivo. Após a fixação destas bactérias na superfície metálica e o meio corrosivo contendo nutrientes há consequentemente o crescimento e a multiplicação da bactéria.

Dada a variedade de ambientes que podem proporcionar crescimento de bactérias, fungos e algas, muitos são os equipamentos que podem sofrer a CIM. Entre esses ambientes podem ser citados a água do mar, de rios e de sistemas de refrigeração, sedimentos oleosos, solos contendo resíduos orgânicos ou sais como sulfatos, sulfetos, nitratos, fosfatos, enxofre, entre outros (GENTIL, 1996).

Segundo as estatísticas, a CIM é responsável por $20 \%$ em danos causados por corrosão em metais e materiais de construção (XU, 2012).

A seguir, são mostrados com mais detalhes os principais tipos de corrosão causada por microrganismos.

\subsubsection{1}

\section{Pilhas de Aeração Diferencial}

De acordo com DANTAS (1988) as pilhas de aeração diferencial, formadas pela deposição de um biofilme sobre superfícies metálicas, representam mais de $70 \%$ dos casos de corrosão em sistemas que utilizam água de refrigeração.

Neste caso, diversos microrganismos formam depósitos que ficam aderidos na superfície metálica sob a forma de biofilmes. Abaixo desse depósito, cria-se uma região deficiente em oxigênio, que é o anodo (onde ocorre a oxidação, perda de elétrons), enquanto a parte mais aerada é o catodo (onde ocorre a redução, ganho de elétrons), iniciando o processo corrosivo por aeração diferencial. Também é 
possível o desenvolvimento de bactérias anaeróbicas abaixo do biofilme, como as bactérias redutoras de sulfato, que também são corrosivas.

Os produtos de corrosão oriundos do anodo se avolumam sobre o depósito inicial, formando os tubérculos. Após a formação dessas pilhas, o seu crescimento independe das concentrações de inibidores de corrosão existentes na água de resfriamento, evidenciando a gravidade da sua presença, para os metais do sistema (DANTAS, 1998).

As reações 1 e 2 expressam as reações que ocorrem nas regiões anódicas e catódicas.

- Anodo

$\mathrm{Fe} \rightarrow \mathrm{Fe}^{2+}+2 \mathrm{e}^{-}$

- Catodo

$\mathrm{H}_{2} \mathrm{O}+2 \mathrm{e}-+1 / 2 \mathrm{O}_{2} \rightarrow 2 \mathrm{OH}^{-}$

Os íons metálicos $\mathrm{Fe}^{2+}$ migram em direção ao catodo e os íons hidroxila $\mathrm{OH}^{-}$ em direção ao anodo e o hidróxido ferroso, $\mathrm{Fe}(\mathrm{OH})_{2}$ se forma em uma região intermediária entre o catodo e o anodo (reação 3).

$\mathrm{Fe}^{2+}+2 \mathrm{OH}^{-} \rightarrow \mathrm{Fe}(\mathrm{OH})_{2}$

Na presença de oxigênio no meio ocorre a oxidação do hidróxido ferroso e consequentemente a geração de hidróxido férrico, $\mathrm{Fe}(\mathrm{OH})_{3}$ (reação 4). Posteriormente, ele perde água e transforma-se no óxido de ferro (III) monohidratado $\left(\mathrm{Fe}_{2} \mathrm{O}_{3} \cdot \mathrm{H}_{2} \mathrm{O}\right)$, também conhecido como ferrugem (reação 5).

$2 \mathrm{Fe}(\mathrm{OH})_{2}+1 / 2 \mathrm{O}_{2}+\mathrm{H}_{2} \mathrm{O} \rightarrow 2 \mathrm{Fe}(\mathrm{OH})_{3}$

$2 \mathrm{Fe}(\mathrm{OH})_{3} \rightarrow \mathrm{Fe}_{2} \mathrm{O}_{3} \cdot \mathrm{H}_{2} \mathrm{O}+2 \mathrm{H}_{2} \mathrm{O}$

A figura 2.7 representa as reações deste tipo de corrosão do aço carbono em sistemas de resfriamento. 


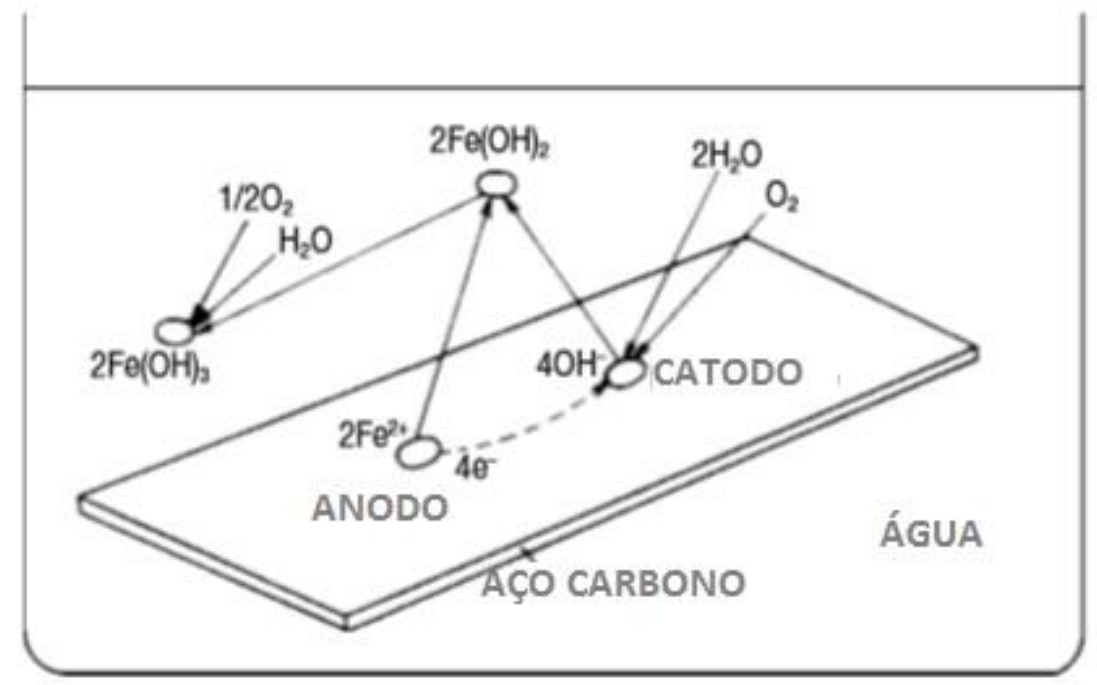

Figura 2.7: Reações de corrosão do aço carbono. (Fonte: adaptado de SUZUKI, 1999).

\subsubsection{2}

\section{Corrosão pelas Bactérias Redutoras de Sulfato}

As bactérias redutoras de sulfato (BRS) são anaeróbias, heterotróficas, obtém energia para seu crescimento a partir de reações de oxi-redução de substratos orgânicos em ausência de oxigênio, tolerando temperaturas de até $80^{\circ} \mathrm{C}$ e pH entre 5 e 9 . O oxigênio que no metabolismo das bactérias aeróbias atua como receptor de elétrons é substituído neste caso, pelo sulfato. Os produtos finais de metabolismo são os sulfetos (de ferro ou hidrogênio) e ácido sulfídrico (MAINIER, 2007).

As reações 6, 7, 8, 9, 10 e 11 estão envolvidas nessas etapas (DANTAS, 1998).

- Reação anódica

$4 \mathrm{Fe} \rightarrow 4 \mathrm{Fe}^{2+}+8 \mathrm{e}$

- Região catódica

$8 \mathrm{H}_{2} \mathrm{O}+8 \mathrm{e} \rightarrow 8 \mathrm{OH}^{-}+8 \mathrm{H}$

- Despolarização

$\mathrm{SO}_{4}{ }^{2-}+8 \mathrm{H} \rightarrow \mathrm{S}^{2-}+4 \mathrm{H}_{2} \mathrm{O}+$ energia

- Produtos finais de corrosão

$4 \mathrm{Fe}^{2+}+\mathrm{S}^{2-}+6 \mathrm{OH}^{-} \rightarrow \mathrm{FeS}+3 \mathrm{Fe}(\mathrm{OH})_{2}$ 
- Reação Global

$4 \mathrm{Fe}^{2+}+\mathrm{SO}_{4}{ }^{2-}+4 \mathrm{H}_{2} \mathrm{O} \rightarrow \mathrm{FeS}+3 \mathrm{Fe}(\mathrm{OH})_{2}+2 \mathrm{OH}^{-}$

Este grupo de bactérias compreende diferentes gêneros, sendo segundo Dantas (1998) o Desulfovibrio o de maior interesse em águas de resfriamento.

\subsubsection{3}

\section{Corrosão pelas Bactérias Oxidantes de Ferro}

Por intermédio de enzimas, esse grupo de bactérias catalisa a reação de transformação de $\mathrm{Fe}^{2+}$ solúvel existente na água, para $\mathrm{Fe}^{3+}$ insolúvel. A reação de oxidação do ferro ferroso a férrico pode ser observada na reação 12.

$2 \mathrm{Fe}\left(\mathrm{HCO}_{3}\right)_{2}+1 / 2 \mathrm{O}_{2}=\mathrm{Fe}_{2} \mathrm{O}_{3} \cdot 2 \mathrm{H}_{2} \mathrm{O}+4 \mathrm{CO}_{2}+$ energia

Entre as bactérias oxidantes de ferro as mais comuns são dos gêneros Leptothrix, Gallionella e Siderocapsa (DANTAS, 1998). Algumas oxidam manganês e outros metais, mas as mais conhecidas são as ferrobactérias, cujo metabolismo efetua oxidação do composto de ferro, oxidando íon ferroso à férrico e gerando precipitados de hidróxido de ferro sobre as superfícies metálicas. Os produtos finais do metabolismo são, principalmente, hidróxido férrico e sulfato férrico (HERRO, 1993; FLYNN 2009 apud VEIGA, 2010).

O óxido ou hidróxido de ferro III formado pode ficar aderido em forma de tubérculos nas paredes da tubulação, causando problemas na troca de calor e restringindo a vazão da tubulação nos sistemas de resfriamento, além de criarem condições para ocorrência de corrosão por aeração diferencial.

\subsubsection{4}

\section{Corrosão pelas Bactérias Oxidantes de Enxofre}

Esses microrganismos utilizam enxofre como nutriente e por isso são denominadas bactérias oxidantes de enxofre. Estas bactérias formam biofilme e geram um meio favorável a corrosão no sistema. De acordo com DANTAS (1998), o gênero mais importante deste grupo de bactérias é o Thiobacillus, se destacando 
as seguintes espécies: Thiobacillus thioparus e Thiobacillus concretivorus, todas gram-negativas, aeróbicas e em forma de bastonete.

Este grupo de bactéria oxida enxofre e seus compostos a sulfato, com produção de ácido sulfúrico, que é corrosivo. Os compostos de enxofre são normalmente o sulfito $\left(\mathrm{SO}_{3}{ }^{2-}\right)$, o tiossulfato $\left(\mathrm{S}_{2} \mathrm{O}_{3}{ }^{2-}\right)$ e diversos politionatos como o tetrationato $\left(\mathrm{S}_{4} \mathrm{O}_{6}{ }^{2-}\right)$.

A reação de oxidação do enxofre está exemplificada na reação 13.

$$
2 \mathrm{~S}+3 \mathrm{O}_{2}+2 \mathrm{H}_{2} \mathrm{O}=2 \mathrm{H}_{2} \mathrm{SO}_{4}
$$

A temperatura ótima para crescimento dessas bactérias está na faixa de 25 ${ }^{\circ} \mathrm{C}-30{ }^{\circ} \mathrm{C}$ e seus processos metabólicos podem ocasionar valores de $\mathrm{pH}$ em torno de 2 (GENTIL, 1996).

\subsection{4}

\section{Fatores que Influenciam o Crescimento Microbiano}

Diversos fatores podem propiciar o crescimento de microrganismos em sistemas de resfriamento, dentre eles:

- Nutrientes

Os nutrientes entram nos sistemas de resfriamento através da água de reposição, pelo ar ou por vazamentos de fluidos do processo de trocadores de calor (SUZUKI, 1999; XU, 2012). Na tabela 2-2 são pontuados os nutrientes requeridos para o metabolismo dos principais tipos de microrganismos presentes em águas de resfriamento.

Grande parte das bactérias cresce através da oxidação de substâncias orgânicas. Portanto, em águas com maior teor de matéria orgânica, mais elevada será a carga microbiana.

- $\mathrm{pH}$

Geralmente, as bactérias crescem bem em uma faixa de $\mathrm{pH}$ neutro. $\mathrm{O} \mathrm{pH}$ ideal para seu crescimento está na faixa de 6 a $9 . \mathrm{O}$ pH da água de resfriamento normalmente é controlado na faixa de 6,5 a 9, a fim de evitar processos corrosivos (SUZUKI, 1999). 
- Temperatura

Cada microrganismo apresenta uma temperatura de crescimento ótima, conforme é demonstrado na tabela 2-3. Além disso, nos processos de resfriamento, são encontrados diversos gradientes de temperatura ao longo do circuito, entre $25^{\circ} \mathrm{C}$ e $35^{\circ} \mathrm{C}$ (GREGORIO et al., 2017), favorecendo o crescimento de certas espécies de modo localizado (TROVATI, 2004). As bactérias, de modo geral, preferem temperaturas na ordem de $35{ }^{\circ} \mathrm{C}$ a $40{ }^{\circ} \mathrm{C}$ (SUZUKI, 1999).

- Luz solar

As algas realizam fotossíntese utilizando luz solar, portanto, elas se desenvolvem em ambientes expostos ao sol, como em bacias de torres de resfriamento.

- Oxigênio dissolvido

As bactérias aeróbias obtêm energia para seu crescimento oxidando substâncias orgânicas, utilizando oxigênio dissolvido. Os sistemas de resfriamento de recirculação aberta fornecem as condições ideais para esses seres, uma vez que oxigênio é suprido pelas torres de resfriamento.

- Turbidez

O aumento da turbidez da água de resfriamento aumenta o acúmulo de material suspenso nas superfícies de baixa vazão de água, criando condições favoráveis para o surgimento de microrganismos.

- Velocidade de escoamento da água

Durante a elaboração do projeto do sistema, deve-se evitar locais com baixa vazão de água, uma vez que estes locais permitem o depósito de material e a adesão do biofilme mais facilmente.

\subsection{5}

\section{Consequências do Crescimento Microbiano em Sistemas de Resfriamento}

De acordo com Trovati (2004), alguns inconvenientes causados pelo excesso de crescimento microbiológico nos sistemas de resfriamento são: 
- Formação de depósitos sobre superfície de troca térmica, diminuindo as taxas de transferência de calor;

- Obstrução e entupimento de tubos, válvulas, equipamentos, acessórios, podendo diminuir a eficiência do processo e restringir a vazão.

- Formação de lodo no fundo das bacias, criando condições propícias para o surgimento de novas espécies de microrganismos;

- Obstrução e crescimento exagerado em recheios e colmeias das torres, diminuindo a eficiência no resfriamento da água;

- As substâncias mucilaginosas (glicocálice) excretadas por alguns seres podem combinar-se com material inorgânico e formar incrustações aderentes nos equipamentos e tubulações;

- Os depósitos de microrganismos sobre as superfícies metálicas aumentam a incidência de processos corrosivos.

\section{5}

\section{Tratamento de Águas de Resfriamento}

As águas dos sistemas de resfriamento devem ser corretamente tratadas, com objetivo de prevenir a corrosão, incrustações, depósitos e crescimento biológico, os quais podem diminuir a vida útil dos equipamentos e interferir na eficiência da troca térmica (DANTAS, 1988).

Este item possui como ponto focal o tratamento biocida em sistemas de resfriamento, objeto deste estudo.

\subsection{1}

\section{Tratamento Biocida}

A aplicação de biocidas, compostos químicos tóxicos, cujo propósito é eliminar os microrganismos indesejáveis ou inibir o crescimento dos mesmos, de tal forma que não causem danos ao processo de troca térmica é um método de controle químico amplamente utilizado para tratamento de águas de resfriamento (DANTAS, 1988). A função destes baseia-se na capacidade de supressão do 
crescimento e/ou atividade metabólica microbiana, tendo como propósito a eliminação ou o controle dos microrganismos associados ao CMI (TELANG et al., 1998). Os biocidas previnem, inibem, diminuem ou eliminam a ação microbiana, através de ataques aos componentes celulares funcionais, promovendo estresse aos microrganismos. Como alvos dos biocidas, encontram-se: a parede celular, os componentes da membrana citoplasmática e o citoplasma (DANTAS, 1988).

Segundo Mi (2005, apud XU, 2012), de acordo com o mecanismo, os biocidas podem ser classificados em duas categorias: Oxidantes e não oxidantes. Os biocidas oxidantes são geralmente oxidantes fortes e seu mecanismo é matar microrganismos oxidando suas enzimas que são importantes no metabolismo. Já os biocidas não oxidantes agem diretamente em partes específicas do corpo.

A eficiência na desinfecção é fortemente influenciada pela composição do biocida, sua concentração, tempo de reação produto-bactérias, temperatura e pH do meio (CERVER, 1990 apud ALASRI, 1992).

Os locais onde o biocida atua são essencialmente componentes da parede celular, membrana citoplasmática, proteínas funcionais e estruturais, RNA, DNA, entre outros componentes citoplasmáticos (CLOETE ET AL., 1998).

Hipoclorito de sódio e de cálcio, ozônio, dióxido de cloro, peróxido de hidrogênio, isotiazolonas, glutaraldeído, sais quaternários de amônio, peróxido de hidrogênio e ácido peracético são alguns exemplos de biocidas, sendo relatados nos próximos itens.

\subsubsection{1}

\section{Cloro e seus compostos}

O tratamento biocida com cloro é amplamente utilizado no tratamento de águas, a fim de reduzir a contaminação microbiana e prevenir a disseminação de patógenos no meio ambiente. No entanto, apesar de ser comprovado em diversos estudos como eficiente no controle de microrganismos e ser atrativo do ponto de vista financeiro, o cloro pode reagir com substâncias orgânicas naturais (ácidos húmicos e fúlvicos), dando origem a inúmeros subprodutos de desinfecção com atividade mutagênica e/ou carcinogênica (CREBELLI et al., 2005).

A aplicação do cloro no tratamento de águas de resfriamento se baseia na formação do ácido hipocloroso $(\mathrm{HClO})$ e íon hipoclorito $\left(\mathrm{ClO}^{-}\right)$, através 
principalmente do cloro gasoso, hipoclorito de cálcio e hipoclorito de sódio, como demonstrado nas reações 14, 15, 16 e 17 . O HClO é o principal responsável pela ação oxidante do composto. De acordo com Gray (1994, apud PERES, 2006), o efeito biocida do $\mathrm{HClO}$ é 80 vezes maior que do $\mathrm{ClO}^{-}$. A presença desses produtos é dependente do $\mathrm{pH}$ e essa relação pode ser observada na figura 2.8. Em uma água clorada, o cloro molecular $\mathrm{Cl}_{2}$ está presente em faixa de $\mathrm{pH}$ igual ou menor que 2 , o ácido hipocloroso predomina em valores de $\mathrm{pH}$ entre 4,0 e 7,5 e o íon hipoclorito domina na faixa de $\mathrm{pH}$ entre 7,5 e 9,5 (DANTAS, 1988). Ou seja, como em valores elevados de $\mathrm{pH}$ a proporção de $\mathrm{ClO}^{-}$aumenta, o efeito de desinfecção nessa faixa diminui.

\section{- Cloro Gasoso}

Quando o cloro é dissolvido na água, forma ácido hipocloroso e ácido clorídrico, conforme reação 13 .

$\mathrm{Cl} 2(\mathrm{~g})+\mathrm{H} 2 \mathrm{O}(\mathrm{aq})=\mathrm{HClO}(\mathrm{aq})+\mathrm{HCl}(\mathrm{aq})$

- Hipoclorito de Cálcio

Quando dissolvido na água, forma ácido hipocloroso e hidróxido de cálcio, segundo a reação 14 .

$\mathrm{Ca}(\mathrm{ClO}) 2(\mathrm{aq})+\mathrm{H} 2 \mathrm{O}(\mathrm{aq})=2 \mathrm{HClO}(\mathrm{aq})+\mathrm{Ca}(\mathrm{OH}) 2(\mathrm{aq})$

- Hipoclorito de Sódio

O hipoclorito de sódio, ao se dissolver na água forma ácido hipocloroso e hidróxido de sódio, conforme reação 15 .

$\mathrm{NaClO}(\mathrm{aq})+\mathrm{H} 2 \mathrm{O}(\mathrm{aq})=\mathrm{HClO}(\mathrm{aq})+\mathrm{NaOH}(\mathrm{aq})$

O ácido hipolocoroso formado nas reações 14, 15 e 16 é um ácido fraco, cuja tendência de dissociação acarreta a formação de íon hipoclorito, segundo a reação 16. 
$\mathrm{HClO}(\mathrm{aq})=\mathrm{H}^{+}(\mathrm{aq})+\mathrm{ClO}^{-}(\mathrm{aq})$

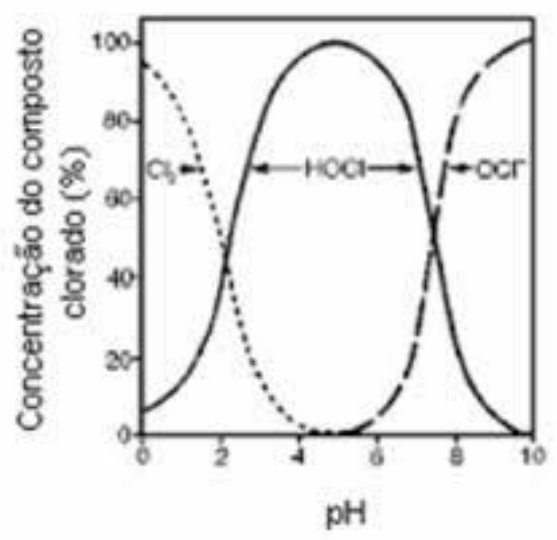

Figura 2.8: Cloro gasoso, ácido hipocloroso e íon hipoclorito em função do pH. (Fonte: TROVATI, 2014).

O cloro, além de possuir como inconveniente a formação de subprodutos tóxicos, é considerado corrosivo para metais, especialmente cobre e ligas de cobre, materiais muito utilizados em sistemas de resfriamento. Portanto, a concentração residual de cloro na água deve ser controlada e deve-se em conjunto com o biocida aplicar inibidores de corrosão (SUZUKI, 1999).

\subsubsection{2}

Ozônio

O ozônio é uma forma alotrópica do oxigênio. Possui alta volatilidade, é pouco solúvel e pouco estável, portanto, sua produção deve ocorrer no próprio local de utilização. É um ótimo oxidante e extremamente efetivo contra grande parte das bactérias e biofilmes bacterianos em sistemas industriais (PERES, 2006).

O ozônio, dosado corretamente, é totalmente consumido na água do sistema de resfriamento não produzindo subprodutos orgânicos halogenados e tóxicos ao meio ambiente (FLYNN, 2009 apud VEIGA, 2010). Por este motivo, é considerado um biocida seguro ambientalmente.

Strittmatter et al. (1992) estudaram a aplicação do ozônio em sistemas de resfriamento. Neste trabalho, as fortes propriedades biocidas do ozônio resultaram em excelente controle microbiológico em todos os estudos de caso. Os autores 
concluíram que a alta eficiência como desinfetante durante o tratamento sem descarga tóxica torna o ozônio um atraente biocida.

No entanto, o ozônio possui limitações: decompõe-se rapidamente na água, seu tempo de meia-vida em água pura é de poucas horas, porém nas águas utilizadas para fins de resfriamento, a meia-vida é reduzida para minutos pela oxidação da matéria orgânica presente e sua taxa de de decomposição também depende do $\mathrm{pH}$ da água, sendo maior em valores de pH alcalinos (DI PIPPO et al., 2018).

A grande desvantagem deste produto é seu alto custo, o que o torna pouco competitivo comparado aos principais biocidas utilizados na atualidade (PERES, 2006).

\subsubsection{3}

\section{Peróxido de Hidrogênio}

O peróxido de hidrogênio é um desinfetante com propriedades bactericidas e esporicidas. Este produto é eficaz contra uma ampla gama de bactérias, incluindo muitas que se tornaram resistentes a produtos químicos clorados, como Pseudomonas aeruginosa. No entanto, o peróxido de hidrogênio pode ser usado em conjunto com outros desinfetantes, como radiação ultravioleta e ozônio. Este processo é conhecido como peroxona. Este biocida em si não é reativo e, portanto, não é bactericida (CLOETE et al., 1998). Uma das vantagens do peróxido de hidrogênio é a não geração de subprodutos tóxicos ao se decompor gradualmente em oxigênio e água (VEIGA, 2010).

Já existem alguns estudos que testaram a eficiência do peróxido de hidrogênio no tratamento de águas de resfriamento em detrimento do cloro.

Peres (2006) comparou a eficiência dos dois produtos em diferentes condições de estudo em uma amostra de água de resfriamento de uma indústria siderúrgica localizada no Rio de Janeiro. $\mathrm{O}$ autor mostrou que o efeito biocida do peróxido de hidrogênio é mais limitado que o cloro e sua eficiência depende do tempo de contato e também pode ser afetada pelas impurezas dissolvidas na água.

Veiga (2010) também comparou estes mesmos biocidas sobre o controle do crescimento microbiano e as taxas de corrosão em sistemas de resfriamento. $\mathrm{O}$ estudo mostrou que o cloro promoveu melhor controle sobre as bactérias planctônicas, mas em relação as taxas de corrosão e a formação de biofilmes, ambos biocidas apresentaram resultados semelhantes. 
Alasri et al., (1992) demonstraram que as atividades bactericidas do peróxido de hidrogênio são mais baixas que do APA e cloro.

\subsubsection{4 \\ Isotiazolonas}

São compostos com amplo espectro de ação contra bactérias, fungos e algas. Esse biocida reage no citoplasma das células com os grupos "tiol" presentes nas enzimas e proteínas estruturais. A ação biocida é lenta, em torno de 4 a 12 horas, mas é um bacteriostático imediato. Atuam em pH entre 6 e 9 e possui como principal desvantagem a sua desativação por formas reduzidas de enxofre (TROVATI, 2004).

\subsubsection{5}

\section{Glutaraldeído}

O seu tempo de ação é de 3 a 8 horas e seu princípio de funcionamento baseia-se em ligações cruzadas com os grupos amino (de proteínas estruturais e enzimas) na superfície das células. Atua em valores de $\mathrm{pH}$ de 6 a 9 e como inconvenientes: reage com amônia e a sofre desativação por sulfitos (TROVATI, 2004).

\subsubsection{6}

\section{Sais Quaternários de amônio}

São compostos catiônicos que tendem a se adsorver nas superfícies negativamente carregadas das células dos microrganismos, afetando a permeabilidade celular e causando a sua destruição, apresenta ação rápida (poucas horas), possui amplo espectro de ação contra fungos, bactérias anaeróbias e aeróbias e algumas classes de algas, sendo efetivo numa faixa de pH entre 5,0 e 9,0 (TROVATI, 2004).

A principal desvantagem deste biocida é a sua incompatibilidade com inibidores de corrosão e incrustação utilizados no tratamento de águas de resfriamento. 


\subsubsection{7}

\section{Ácido Peracético}

Desde a década de quarenta, as aplicações do APA vêm sendo pesquisadas e a partir disso, sua eficiência como bactericida, fungicida, esporicida e virucida têm sido relatadas por diversos autores (CAVALLINI et al., 2012).

O APA é um agente antimicrobiano potente devido ao seu alto potencial oxidante. É altamente eficaz contra uma ampla gama de microrganismos e é utilizado como desinfetante nas indústrias alimentícia e médica (MARTíNESPADA, 2013).

O APA é preparado a partir de peróxido de hidrogênio e ácido acético. Esta reação é reversível e assim uma mistura de equilíbrio de reagentes e produtos é obtida. A taxa na qual o equilíbrio é alcançado pode ser acelerada pela adição de um catalisador, geralmente ácido sulfúrico (ZHAO, 2007), conforme reação abaixo:

$$
\mathrm{CH}_{3} \mathrm{COOH}+\mathrm{H}_{2} \mathrm{O}_{2}=\mathrm{CH}_{3} \mathrm{COOOH}+\mathrm{H}_{2} \mathrm{O}
$$

Comercialmente o APA é produzido nas concentrações de até $15 \%(\mathrm{~m} / \mathrm{m})$, acima de $15 \%$ aumenta a sua instabilidade e reatividade (CAVALLINI, 2012).

Aslari et al. (1992) estudaram a concentração bactericida mínima de quatro desinfetantes: APA, peróxido de hidrogênio, formaldeído e cloro no combate a E.Coli. O trabalho concluiu que o poder biocida do APA não é dependente de grande tempo de contato, ou seja, em 5 minutos após sua aplicação o seu efeito desinfetante já demonstra altamente eficiente, vantagem significativa em relação aos outros produtos. Ainda de acordo com os autores, o cloro não é efetivo em tempos de contato de 5 minutos, a sua ação bactericida cresce cerca de quatro vezes após um tempo de contato de 3 horas.

Martín-Espada (2013) estudou a eficácia do APA contra biofilmes de Pseudomonas aeruginosa cultivados em superfícies de poliestireno e o mesmo alcançou a eficácia de $100 \%$ sobre essa espécie de bactéria.

Ceretta (2008) avaliou a eficiência do APA na esterilização de equipamentos odontológicos. Os resultados deste estudo indicaram um efeito positivo da utilização do produto como desinfetante destes materiais. 
Baldry et al. (1995) estudaram o uso do APA no tratamento de efluentes em regiões tropicais e temperadas quentes, avaliando a eficácia da atividade deste produto contra Vibrio cholerae, um organismo de preocupação médica. Os experimentos mostraram que o APA é um bom produto desinfetante e mais eficaz que o hipoclorito de sódio contra espécies de Vibrio cholerae e sua atividade melhora a temperaturas mais altas.

Cavalinni et al. (2012) avaliaram a utilização do APA na desinfecção de esgoto sanitário e concluíram que a ação desinfetante do APA ocorre mesmo na presença de matéria orgânica, porém, o aumento da DQO e dos sólidos em suspensão do efluente diminuem a eficiência de desinfecção do biocida. Em comparação ao cloro, apresentou resultados de toxicidade e formação de subprodutos inferiores ao cloro na desinfecção de esgoto.

Crebelli et al. (2004) investigaram a influência do APA e hipoclorito de sódio $(\mathrm{NaClO})$ na formação de subprodutos mutagênicos em amostras de águas residuais coletadas em uma estação de tratamento de água. Os autores sugeriram que a desinfecção de esgoto com doses moderadas de APA não leva à formação de uma quantidade significativa de subprodutos com atividade mutagênica e/ou carcinogênica.

Rossi et al. (2007) pesquisaram a desinfecção de efluentes com APA como uma alternativa ao hipoclorito de sódio. Segundo os autores, a concentração ativa de APA depende do consumo inicial de oxidação e do decaimento natural do mesmo, que segue a cinética de primeira ordem. Como consequência, para escolha da dose do APA a ser aplicada, ambos os fatores devem ser levados em consideração, particularmente o último, que implica uma perda de 25 a $30 \%$ do APA inicial, após 1 hora de contato.

Pode-se observar que o APA é utilizado como biocida em diversos processos industriais, e seu poder como desinfetante tem se mostrado eficiente. Porém, antes da escolha do melhor tratamento químico, deve-se também levar em consideração outros aspectos importantes: $\mathrm{O}$ custo, ou seja, quanto menor a concentração eficaz do biocida aplicada e sua estabilidade na água tratada, mais viável se torna o produto; deve-se conhecer as suas características tóxicas; o produto escolhido deve ser de preferência sem características de periculosidade; e também deve possuir amplo espectro de ação de forma a atuar em diferentes tipos de microrganismos (DANTAS, 1988). 
A eficiência de desinfecção do APA pode variar conforme o tempo de contato, a temperatura, o pH, o teor de matéria orgânica e de sólidos dissolvidos e o seu potencial de oxidação. (CAVALLINI et al., 2012).

De acordo com a composição do APA, na forma comercial, o peróxido de hidrogênio e o ácido acético presentes no produto reforçam a sua ação desinfetante, porém, o APA é mais potente que o peróxido, agindo contra uma gama maior de microrganismos de forma mais rápida e em concentrações mais baixas (CAVALLINI et al. 2012).

Existem três reações nas quais o APA é consumido em uma solução aquosa: decomposição espontânea, hidrólise e decomposição catalisada por metais de transição. A faixa de $\mathrm{pH}$ de 5,5 a 8,2 resulta principalmente na decomposição espontânea em ácido acético e oxigênio (KITIS, 2003).

Atualmente, o valor típico de mercado do APA é o dobro do hipoclorito de sódio, mas como sua dosagem costuma ser menor do que a do composto clorado, o custo total de desinfecção com o APA torna-se competitivo com o do hipoclorito.

A utilização do APA influencia no aumento do conteúdo orgânico na água devido ao ácido acético, que além de já estar presente nas misturas de APA, também é formado após a decomposição do mesmo, podendo acarretar no aumento da carga microbiana (KITIS, 2003).

Há escassez de estudos disponíveis na literatura sobre a utilização do APA como biocida em sistemas de resfriamento. Silva (2013) avaliou a ação biocida do APA e peróxido de hidrogênio na concentração de $50 \mathrm{mg} / \mathrm{L}$, sendo observado uma redução de Unidades Formadoras de Colônia, tanto na fase planctônica como na séssil para Pseudomonas aeruginosa e para BRS. Porém, ainda há necessidade de uma melhor exploração de estratégias de controle microbiano em sistemas de resfriamento, de modo a buscar soluções sustentáveis e ambientalmente seguras, além de viáveis economicamente como alternativas ao cloro.

De acordo com Suzuki (1999), a dosagem utilizada de cloro em sistemas de resfriamento varia entre 0,5 e 1,0 $\mathrm{mg} / \mathrm{L}$, e o biocida é dosado por um período de 3 horas/dia. Logo, torna-se necessário estudos com dosagens comparativas de APA. 


\subsection{2}

\section{Resistência aos Biocidas}

Um complicador ao uso de biocidas é a resistência bacteriana criada aos compostos. Existem dois tipos de resistência: A resistência intrínseca, que é definida como uma propriedade natural controlada por cromossomos de uma célula bacteriana que permite contornar a ação de um biocida. Para que um agente biocida atinja seu local alvo, ele deve conseguir atravessar as camadas celulares externas, podendo esta atuar como uma barreira de permeabilidade limitando a quantidade de biocida que entra em uma célula; e a resistência adquirida, que resulta de alterações genéticas em uma célula e surge por mutação ou pela aquisição de material genético de outra célula (RUSSEL, 1995).

As células do biofilme apresentam uma maior tolerância aos desinfetantes em relação as bactérias planctônicas. Sua resistência aumentada é multifatorial (HEINZEL et al., 1998; BRIDIER et al., 2011; PAL et al., 2015; PIPPO et al., 2018) resultante da adaptação fenotípica, transferências gênicas e mutações (KELLY et al., 2009; HANNAN et al., 2010; PIPPO et al., 2018).

Uma forma de limitar a resistência e é uma prática comum adotada nos tratamentos de águas de sistemas de resfriamento é o uso combinado e/ou alternado de biocidas (TROVATI, 2004; CLOETE et al., 1998).

A deterioração do efeito de um biocida é frequentemente observada quando o mesmo é aplicado continuamente por um longo período de tempo. Isto significa que os microrganismos desenvolveram resistência contra o agente químico ou aqueles que são resistentes ao biocida aplicado sobrevivem e se multiplicam (SUZUKI, 1999). 


\section{6}

\section{Parâmetros Físico-químicos em Águas de Resfriamento}

Os parâmetros físico-químicos relevantes e que devem ser monitorados nas águas em torres de resfriamento são: $\mathrm{pH}$, sólidos totais dissolvidos, sólidos em suspensão, alcalinidade, concentrações de sulfato, ferro, cloreto, sílica, dureza total, entre outros, que podem variar em função em função da região ou da procedência da água (MACHADO, 2004). Na tabela 2.4 pode-se observar os limites recomendados para parâmetros físico-quimicos de águas de reposição em sistemas de resfriamento semi-abertos.

Em águas com valores baixos de $\mathrm{pH}$ a incidência de processos corrosivos aumenta, e valores altos podem gerar precipitação de sais; altos valores de alcalinidade, sólidos totais dissolvidos, sílica e dureza indicam tendência incrustante da água; cloretos e ferro são controlados para evitar processos corrosivos; concentração elevada de sólidos suspensos indica excesso de material orgânico; concentrações pequenas de sulfato ajudam a combater bactérias redutoras de sulfato; e a turbidez permite avaliar o crescimento microbiológico, detectar contaminações externas e concentração excessiva de sais (TROVATI, 2004). 
Tabela 2.4: Qualidade de água de reposição para uso em sistemas de resfriamento com circuitos semi-abertos

(Environmental Protection Agency apud Machado, 2004).

\begin{tabular}{|c|c|}
\hline Parâmetro $^{\mathrm{a}}$ & Limite Recomendado \\
\hline $\mathrm{Cl}^{-}$ & 500 \\
\hline $\begin{array}{l}\text { STD (sólidos totais } \\
\text { dissolvidos) }\end{array}$ & 500 \\
\hline Dureza & 650 \\
\hline Alcalinidade & 350 \\
\hline $\mathrm{pH}$ & $6,9-9,0$ \\
\hline $\begin{array}{c}\text { DQO (Demanda química } \\
\text { de oxigênio) }\end{array}$ & 75 \\
\hline $\begin{array}{l}\text { STS (sólidos totais } \\
\text { suspensos) }\end{array}$ & 100 \\
\hline Turbidez & 50 \\
\hline DBO & 25 \\
\hline $\mathrm{N}-\mathrm{NH}_{4}{ }^{+}$ & 1,0 \\
\hline $\mathrm{PO}_{4}^{-3}$ & 4,0 \\
\hline $\mathrm{SiO}_{2}$ & 50 \\
\hline $\mathrm{Al}^{+3}$ & 0,1 \\
\hline $\mathrm{Fe}^{+2}$ & 0,5 \\
\hline $\mathrm{Mn}^{+2}$ & 0,5 \\
\hline $\mathrm{Ca}^{+2}$ & 50 \\
\hline $\mathrm{Mg}^{+2}$ & 0,5 \\
\hline $\mathrm{HCO}^{3-}$ & 24 \\
\hline $\mathrm{SO}_{4}^{2-}$ & 200 \\
\hline
\end{tabular}

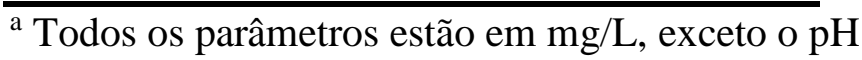




\section{3. \\ Metodologia Experimental e Materiais Utilizados}

\section{1}

\section{Considerações Iniciais}

A metodologia experimental consistiu em testar a eficiência do APA sobre a carga microbiana de amostras de água de resfriamento em quatro condições de estudo. As etapas são expostas detalhadamente nos itens a seguir:

\section{2}

\section{Preparação das Amostras de Água de Resfriamento}

A água utilizada foi obtida da torre de resfriamento de uma indústria química localizada na cidade de Curitiba - Paraná (Peróxidos do Brasil Ltda). As amostras foram transportadas em reservatórios plásticos opacos até o laboratório. Esta foi diluída na proporção de $400 \mathrm{~mL}$ de água da indústria (água mãe) em 1600 mL de água destilada, visto a elevada carga de matéria orgânica da água mãe, não representando caracterização típica de águas encontradas em sistemas de resfriamento. A água apresenta a caracterização fornecida pela Kurita do Brasil LTDA, que atua no tratamento de águas industriais, de acordo com a tabela 3.1. A referida água mãe já veio aditivada com anti-corrosivo (mistura de azol aromático e álcali) e anti-incrustante (fosfonato e polímero sulfônico e acrílico) proprietários da Kurita.

Tabela 3.1: Caracterização da água diluída utilizada nos testes do presente estudo.

\begin{tabular}{cccccccc}
\hline $\begin{array}{c}\text { Turbidez } \\
(\mathbf{N T U})\end{array}$ & $\begin{array}{c}\text { Condutividad } \\
\mathbf{e}(\boldsymbol{\mu} \mathbf{s} / \mathbf{c m})\end{array}$ & $\begin{array}{c}\text { Sílica } \\
(\mathbf{m g} / \mathbf{L})\end{array}$ & $\begin{array}{c}\text { Alcalinida } \\
\text { de total } \\
(\mathbf{m g} / \mathbf{L} \\
\mathbf{C a C O})\end{array}$ & $\begin{array}{c}\text { Dureza } \\
\text { total } \\
(\mathbf{m g} / \mathbf{L} \\
\mathbf{C a C O})\end{array}$ & $\begin{array}{c}\text { Clore } \\
\text { to } \\
(\mathbf{m g} / \\
\mathbf{L})\end{array}$ & $\begin{array}{c}\text { Ferro } \\
\text { total } \\
(\mathbf{m g} / \mathbf{L})\end{array}$ & $\begin{array}{c}\text { DQO } \\
(\mathbf{m g} / \mathbf{L})\end{array}$ \\
\hline 3,4 & 5750 & 1,5 & 111,4 & 191,18 & 90,2 & 0,1 & 69,9 \\
\hline
\end{tabular}


A temperatura da água nos experimentos foi fixada em $32^{\circ} \mathrm{C}$, temperatura média típica de águas de resfriamento, utilizando-se termostatos (modelo H-606 50 watts, Hopar, China).

Foram avaliados dois valores de $\mathrm{pH}(8,0$ e 8,8$)$, estes sendo ajustados no início dos experimentos e monitorado ao longo dos mesmos através de um medidor digital (modelo TPH01102, Yieryi, China).

Para cada condição estudada, foram preparadas três amostras de água de 2 litros a fim de realizar o experimento em triplicata, conforme ilustra a figura 3.1.

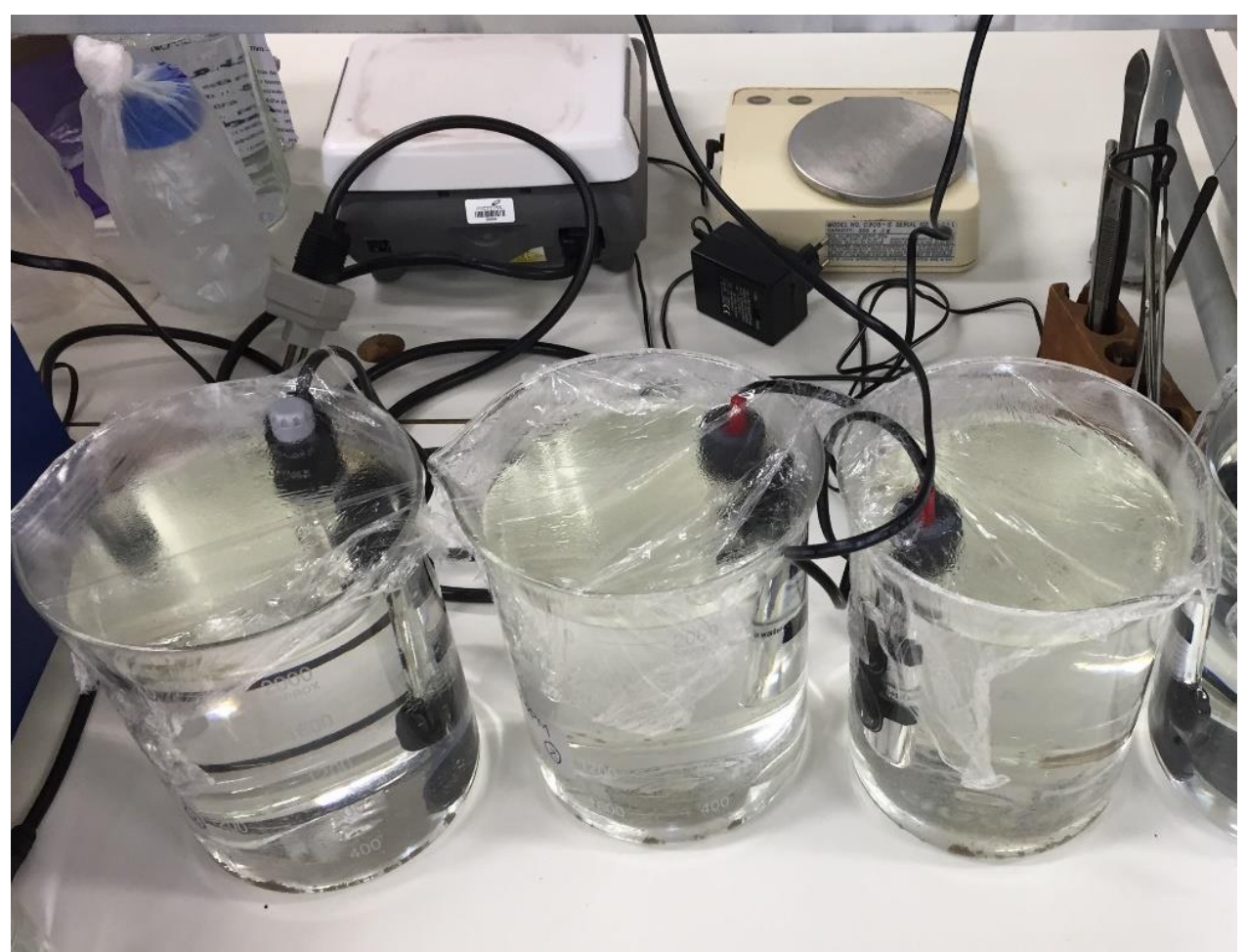

Figura 3.1: Amostras da Água de Resfriamento.

\section{3}

\section{Condições de Estudo}

A eficiência do APA sobre a carga microbiana das amostras de água de resfriamento foi estudada em quatro condições diferentes: Concentrações do biocida de 1,0 mg/L e 2,0 mg/L e valores de $\mathrm{pH}$ 8,0 e 8,8. A tabela 3.1 mostra tais condições. 
Tabela 3.2: Condições da Água de Resfriamento para Análise Bacteriológica.

\begin{tabular}{ccc}
\hline Condição & $\begin{array}{c}\text { Concentração de APA } \\
(\mathbf{m g} / \mathbf{L})\end{array}$ & $\mathbf{p H}$ \\
\hline 1 & 1 & 8,0 \\
2 & 1 & 8,0 \\
3 & 2 & 8,8 \\
4 & 2 & 8,8 \\
\hline
\end{tabular}

Cada experimento foi monitorado em um período de 4 horas/dia, por campanhas de 5 dias, sendo realizadas contagens tanto sem adição do APA, como em diferentes tempos de contato entre o biocida e os grupos bacterianos presentes nas amostras, a fim de avaliar tanto o decaimento dos microrganismos ao longo do tempo, como a velocidade de ação do biocida.

\section{4}

\section{Modo de Adição do Biocida}

As dosagens empregadas de APA foram retiradas de uma solução-mãe preparada a partir do PROXITANE 1512 da Peróxidos do Brasil, Curitiba, Brasil. O produto é uma mistura que contém ácido peracético (15\%), peróxido de hidrogênio (23\%) e ácido acético (16\%).

O biocida foi aplicado no início dos experimentos, e a cada hora sua concentração era medida e corrigida, repondo o biocida até atingir o valor inicial de concentração estabelecida, de forma a manter a sua concentração constante, por um período de 4 horas/dia ao longo das campanhas.

A dosagem do APA por um período de 4 horas/dia (e não continuamente), durante cada campanha, foi determinada com base em estudos de caso de tratamentos químicos descritos por Suzuki (1999). O autor descreve estudos de tratamento de água com diferentes propriedades: Tratamento de água de alta dureza, tratamento de água de baixa dureza, tratamento de água de alta salinidade, onde em todos os casos o biocida é dosado durante um período de $3 \mathrm{~h} / \mathrm{dia}$.

A medição da concentração do biocida foi realizada através do reflectómetro RQflex 10 e os kits de ensaios Reflectoquant, ambos da Merck KGaA, Darmstadt, Alemanha, baseada no método reflectómetro. A metodologia consiste em introduzir 
as tiras de teste na amostra de água durante dois segundos, a seguir, após a retirada do excesso de líquido, a mesma é introduzida no reflectómetro, onde é possível a realização da leitura da concentração do APA em mg/L.

\section{5}

\section{Preparação do Meio de Cultura}

O meio de cultura utilizado foi o APC (Agar Padrão de Contagem). De acordo com as indicações do fabricante, para preparação do caldo adiciona-se 22,5 g do meio em 1 L de água destilada. Em seguida, a solução deve ser homogeneizada e esquentada. Após ferver, a mesma deve ser resfriada e transferida em alíquotas de $20 \mathrm{~mL}$ para as placas petri.

\section{6}

\section{Preparação da Água Peptonada}

Para preparação da água peptonada $0,1 \%$, deve-se adicionar $1 \mathrm{~g}$ de peptona em 1 L de água destilada. Em seguida, transfere-se alíquotas da solução para tubos de ensaio, para utilização nas diluições realizadas nos experimentos.

\section{7}

\section{Inoculações em Placas Petri}

Para todas as contagens foram realizadas alíquotas de $1 \mathrm{~mL}, 0,1 \mathrm{~mL}, 0,01$ $\mathrm{mL}$ e diluição $10^{-4}$ com inóculo $0,1 \mathrm{~mL}$.

Para diluição $10^{-4}$, transfere-se $0,1 \mathrm{~mL}$ das amostras da água para tubos de ensaio contendo 9,9 mL de água peptonada, obtendo-se a diluição $10^{-2}$. Em seguida, 0,1 mL desta diluição foi transferida também para tubos contendo $9,9 \mathrm{~mL}$ de água peptonada, obtendo-se a diluição $10^{-4}$. Por fim, uma alíquota de $0,1 \mathrm{~mL}$ desta diluição é inoculada na placa petri. 


\section{8}

\section{Contagem de Microrganismos}

Antes do início do tratamento e após a adição do biocida, as bactérias heterotróficas aeróbicas mesófilas totais foram enumeradas segundo a metodologia descrita pelo Standard Methods for the Examination of Water and Wastewater (1998), método 9215. Alíquotas de $0,01 \mathrm{~mL}, 0,1 \mathrm{~mL}$ e $1,0 \mathrm{~mL}$ e diluições de $10^{-4}$ com inóculo $0,1 \mathrm{~mL}$ das amostras foram inoculadas em placas petri, em meios de cultura agar padrão para contagem (Merck) e espalhadas com auxílio da alça de Drigalsky. As placas foram incubadas à $25^{\circ} \mathrm{C}$ por até 48 horas.

As colônias foram então enumeradas e o número de unidades formadoras de colônia por mililitro (UFC/mL) foi determinado através da fórmula abaixo (Standard Methods for the Examination of Water and Wastewater, 1998).

$$
\frac{\mathrm{UFC}}{\mathrm{mL}}=\frac{\text { Número de Colônias }}{\text { inóculo }(\mathrm{mL})}
$$

Quando diluições são realizadas o valor encontrado na fórmula acima é multiplicado pelo inverso da diluição correspondente.

Foram executadas cinco análises microbiológicas em cada dia da campanha de 5 dias. A primeira sem adição do biocida, e as outras em diferentes tempos de contato entre biocida-microrganismos: 5 minutos, 1 hora, 2 horas e 4 horas.

\section{9}

\section{Identificação das Estirpes Isoladas por Espectrometria de Massa do Tipo MALDI-TOF}

Microrganismos isolados antes dos experimentos e após o ciclo de tratamento de 5 dias com biocida foram isolados da água e submetidos à identificação por MALDI-TOF. Esta etapa foi realizada em um espectrômetro de massa - Microflex LT (Brucker, Germany), segundo as especificações do fabricante. Em uma breve descrição da metodologia, as cepas criopreservadas foram ativadas em placas de petri contendo Tripticase soy agar (TSA) (Biomerieux, 
Brasil) e incubadas à $37^{\circ} \mathrm{C} / 18 \mathrm{~h}$. Uma fração da colônia de Bactérias foi depositada, em triplicata, em uma placa de metal, sendo adicionado $1 \mu 1$ de matriz composta da solução saturada de ácido $\alpha$-hidroxi-ciano-cinâmico (CHCA). O espectro de massa gerado foi analisado e comparado com banco de dados MALDI Biotyper (Bruker Daltonik, United Kingdom). Como calibrante utilizou-se uma colônia de E.coli DH5 $\alpha$ (LARTIGUE et al., 2009; PAIM et al., 2013). Os critérios de identificação utilizados foram baseados na confiabilidade fornecida pelo equipamento, sendo considerados scores $\geq 2.000$ em que há a identificação em nível de gênero e espécie. 


\section{4.}

\section{Resultados e Discussão}

\section{1}

\section{Considerações Iniciais}

Não existe nenhuma norma de padrão de qualidade para águas utilizadas nos sistemas de resfriamento. No entanto, o limite máximo sugerido por Suzuki (1999) para carga microbiana em águas de resfriamento é da ordem de $10^{3} \mathrm{UFC} / \mathrm{mL}$, porém, sabe-se que em alguns circuitos é aceitável valores até $10^{4} \mathrm{UFC} / \mathrm{mL}$. Neste capítulo, são apresentados os resultados experimentais, bem como a discussão dos mesmos.

\section{2}

\section{Taxa de Decaimento de Ácido Peracético}

Nesta fase experimental, a decomposição / consumo do APA em dosagens iniciais de 1,0 mg/L e 2,0 mg/L na água de estudo em valores de $\mathrm{pH} 8,0$ e 8,8 a temperatura de $32{ }^{\circ} \mathrm{C}$ foi avaliada ao longo de 1 hora, conforme figuras 4.1 e 4.2. 


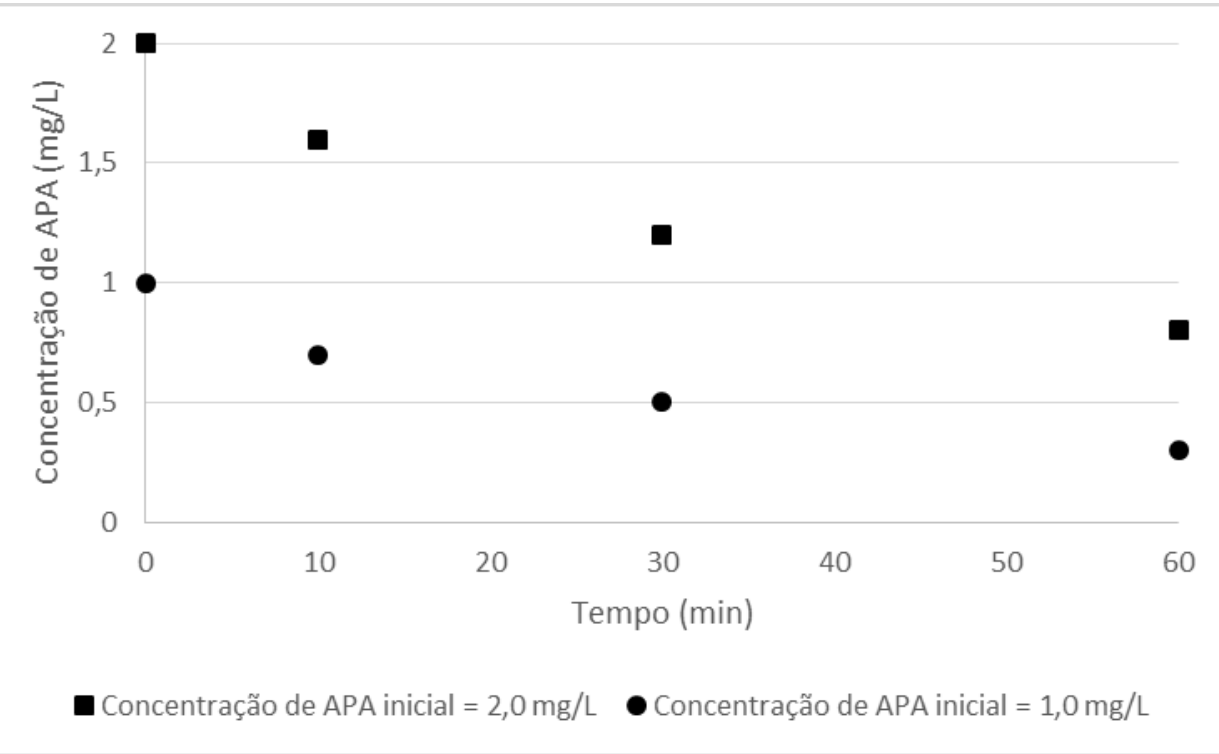

Figura 4.1: Decomposição / consumo do ácido peracético para dosagens iniciais de 1,0 mg/L e 2,0 $\mathrm{mg} / \mathrm{L}$ ao longo de 1 hora quando este foi aplicado nas amostras de água de resfriamento com valor de $\mathrm{pH} 8,0$ e temperatura $32{ }^{\circ} \mathrm{C}$.

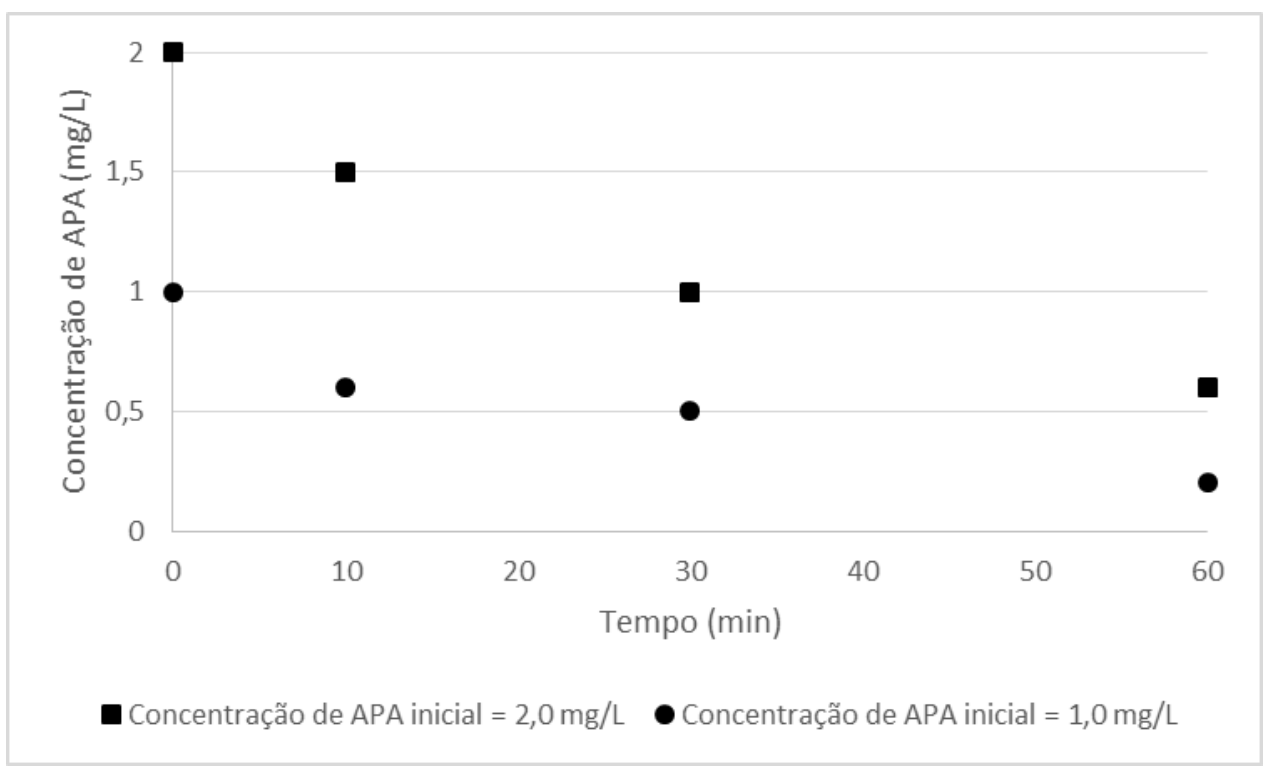

Figura 4.2: Decomposição / consumo do ácido peracético para dosagens iniciais de 1,0 mg/L e 2,0 $\mathrm{mg} / \mathrm{L}$ ao longo de 1 hora quando este foi aplicado nas amostras de água de resfriamento com valor de $\mathrm{pH} 8.8$ e temperatura $32{ }^{\circ} \mathrm{C}$.

Na figura 4.1, pode-se observar que durante o período de 1 hora ocorreu um decaimento de $60 \%$ da concentração de APA quando sua dosagem inicial foi de 2 $\mathrm{mg} / \mathrm{L}$, e $70 \%$ para dosagem inicial de $1 \mathrm{mg} / \mathrm{L}$. Aumentando o valor do $\mathrm{pH}$ para 8,8 e mantendo a mesma temperatura e as mesmas concentrações iniciais do biocida, a 
decomposição do APA foi ligeiramente mais rápida, conforme figura 4.2. Estudos anteriores também observaram que em valores mais elevados de $\mathrm{pH}$ a tendência de decomposição do biocida se acelera.

A rápida decomposição do APA nos dois casos pode ser explicada pela presença de matéria orgânica nas amostras de água, que acelera seu consumo. Além disso, já foi observado que a temperatura também interfere favorecendo a decomposição deste biocida.

Kunigk et al. (2012) estudaram a influência da temperatura e matéria orgânica na decomposição cinética do APA em soluções aquosas sem contaminação e contaminadas com 2,5 e 5,0 g/L de cerveja e leite a diferentes temperaturas. De acordo com a pesquisa, aumentando a temperatura de $20{ }^{\circ} \mathrm{C}$ para $40{ }^{\circ} \mathrm{C}$ as constantes de velocidade observadas da decomposição do APA foram aumentadas em um fator de 2,98 para as soluções com 2,5 g/L de cerveja e em um fator de 4,92 para aquelas com $5 \mathrm{~g} / \mathrm{L}$ deste mesmo contaminante, já as constantes de velocidade de decomposição do biocida observadas nas soluções com 2,5 g/L e 5,0 g/L de leite aumentaram 1,30 e 4,44 vezes, respectivamente, na mesma variação de temperatura, demonstrando que a temperatura e a concentração de matéria orgânica no meio afeta a decomposição do biocida.

Rucker e Cates (1988) também observaram que o aumento da temperatura acelera a decomposição do APA. Os pesquisadores encontraram uma constante de primeira ordem para a decomposição de soluções de APA em meios com pH 7,1, aumentando de $4,572 \cdot 10^{-2} \mathrm{~h}^{-1}$ a $20^{\circ} \mathrm{C}$ para $1,632 \mathrm{~h}^{-1}$ a $50{ }^{\circ} \mathrm{C}$.

Kunigk et al. (2001) mostraram em seus experimentos que a concentração do APA foi reduzida pela metade em 72 horas a $45{ }^{\circ} \mathrm{C}$, mas a $25^{\circ} \mathrm{C}$ a perda em 240 horas foi de apenas $33 \%$.

Em relação a variação de pH, Rucker e Cates (1998) encontraram em seus estudos que a taxa de decomposição do APA tende a aumentar em pH mais alcalino. Os pesquisadores relataram que a taxa de decomposição do APA a $30{ }^{\circ} \mathrm{C}$ aumentou de $0,921 \times 10^{-3} \mathrm{~h}^{-1}$ em soluções de $\mathrm{pH} 5.34$ para $15,5 \times 10^{-3} \mathrm{~h}^{-1} \mathrm{em} \mathrm{pH} \mathrm{8,9.}$ 


\section{3}

\section{Cinética de Decomposição do Ácido Peracético}

A cinética de decomposição do ácido peracético pôde-se ser observada ao longo de 1 hora após a aplicação inicial. A taxa de decaimento do APA é descrita por uma lei cinética de primeira ordem, conforme equação abaixo:

$$
\ln \left(\left[\mathrm{C}_{2} \mathrm{H}_{4} \mathrm{O}_{3}\right] /\left[\mathrm{C}_{2} \mathrm{H}_{4} \mathrm{O}_{3}\right]_{0}\right)=-\mathrm{k} . \mathrm{t}
$$

Onde k é a constante de velocidade para a taxa de reação de decaimento do ácido peracético.

As figuras 4.3, 4.4, 4.5 e 4.6 apresentam resultados da modelagem cinética de primeira ordem da reação para a dosagem inicial de 1,0 mg/L e 2,0 mg/L de APA em $\mathrm{pH} 8,0$ e 8,8, respectivamente.

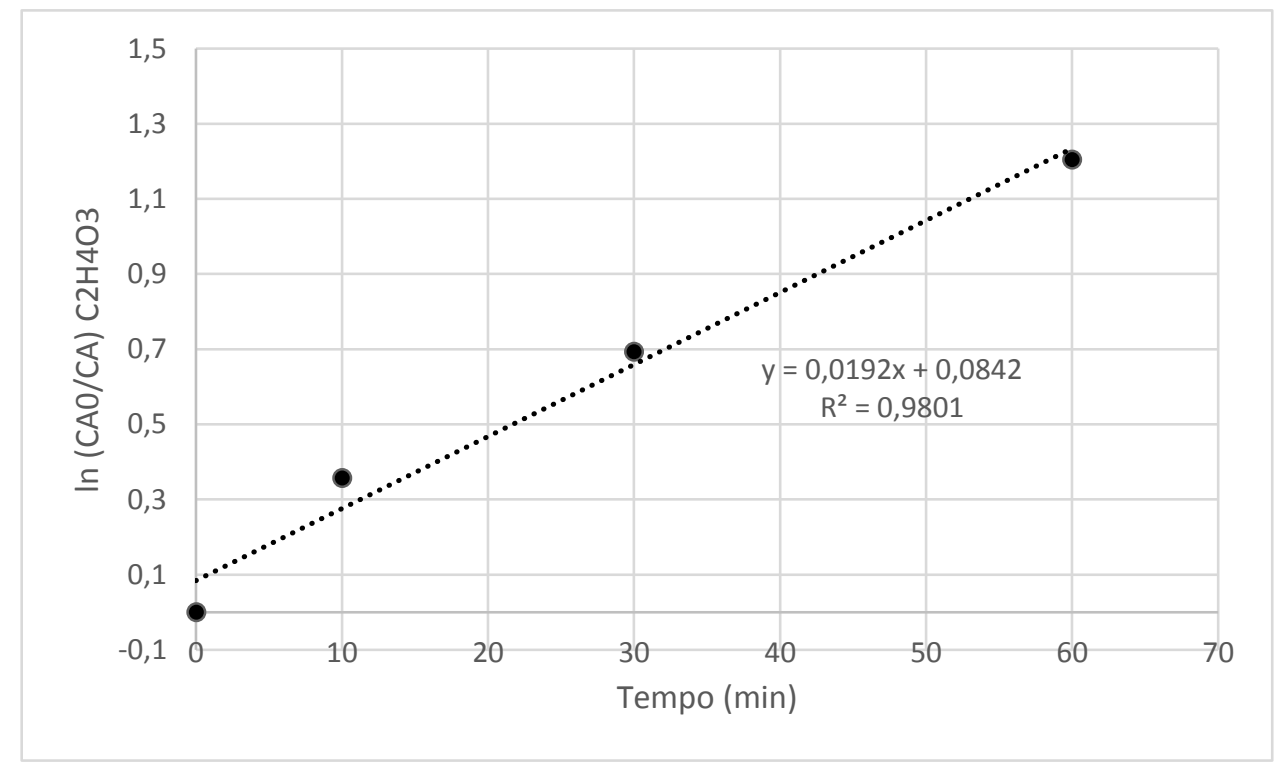

Figura 4.3: Modelo de primeira ordem de reação de decomposição para dosagem inicial de $1,0 \mathrm{mg} / \mathrm{L}$ de APA em $\mathrm{pH} 8,0$. 


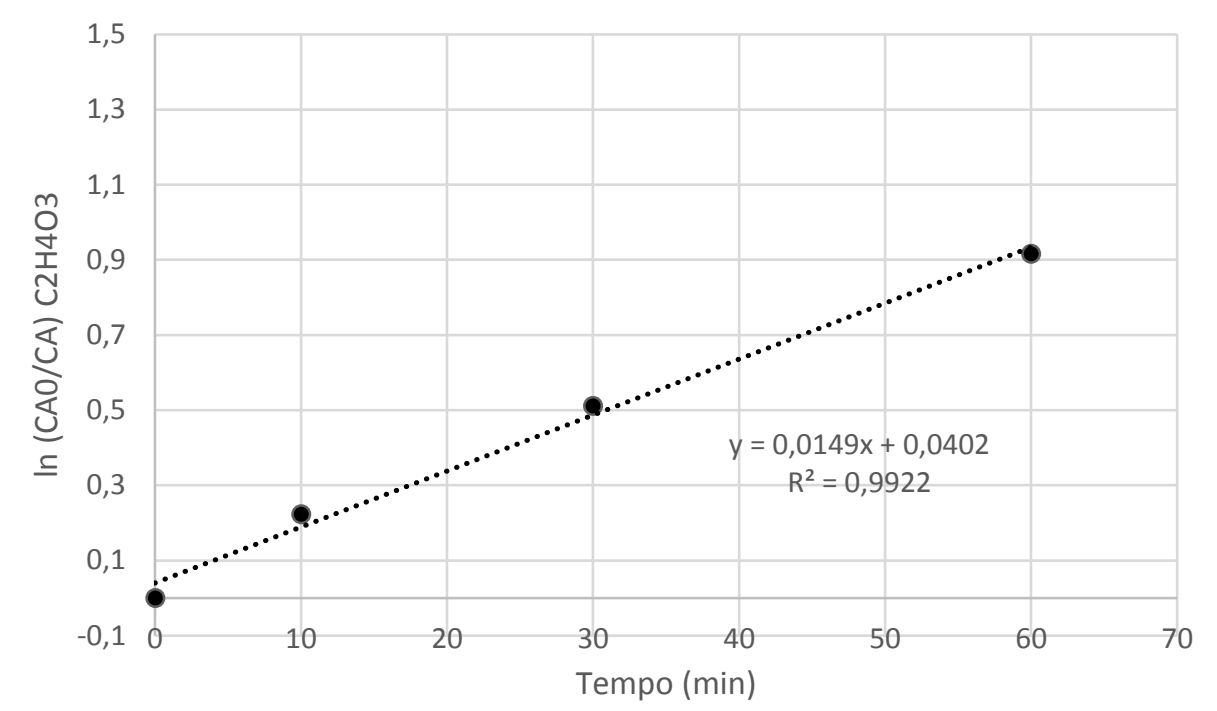

Figura 4.4: Modelo de primeira ordem de reação de decomposição para dosagem inicial de 2,0 $\mathrm{mg} / \mathrm{L}$ de APA em $\mathrm{pH} 8,0$.

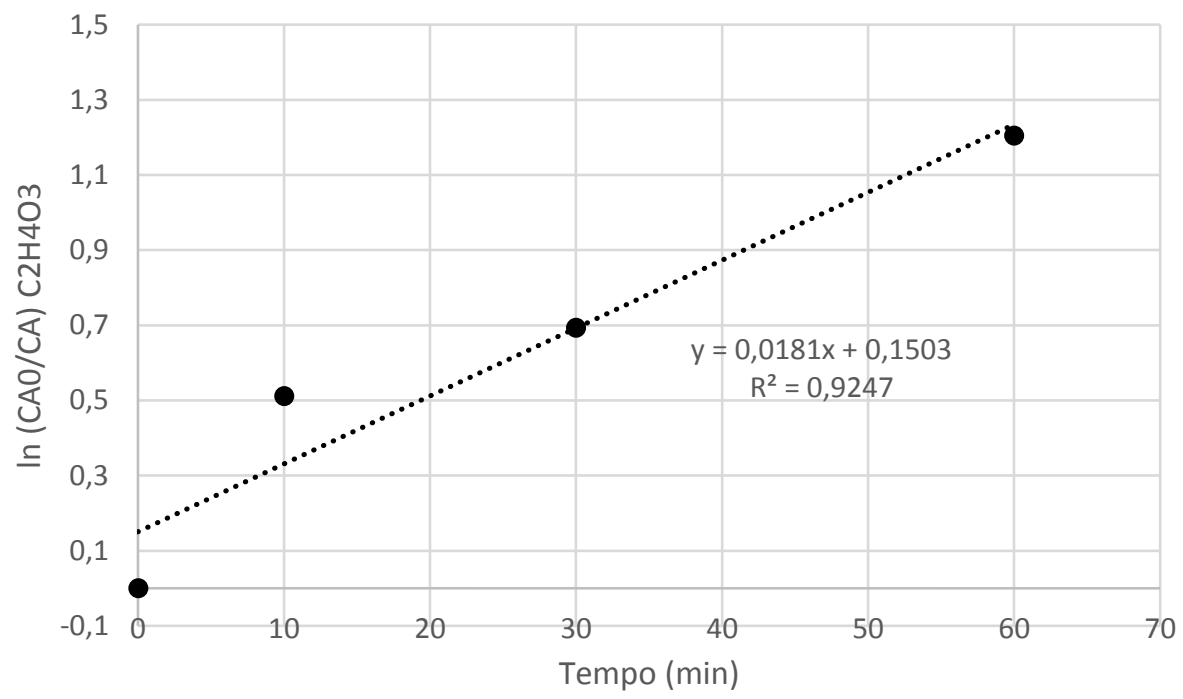

Figura 4.5: Modelo de primeira ordem de reação de decomposição para dosagem inicial de $1,0 \mathrm{mg} / \mathrm{L}$ de APA em $\mathrm{pH} 8,8$. 


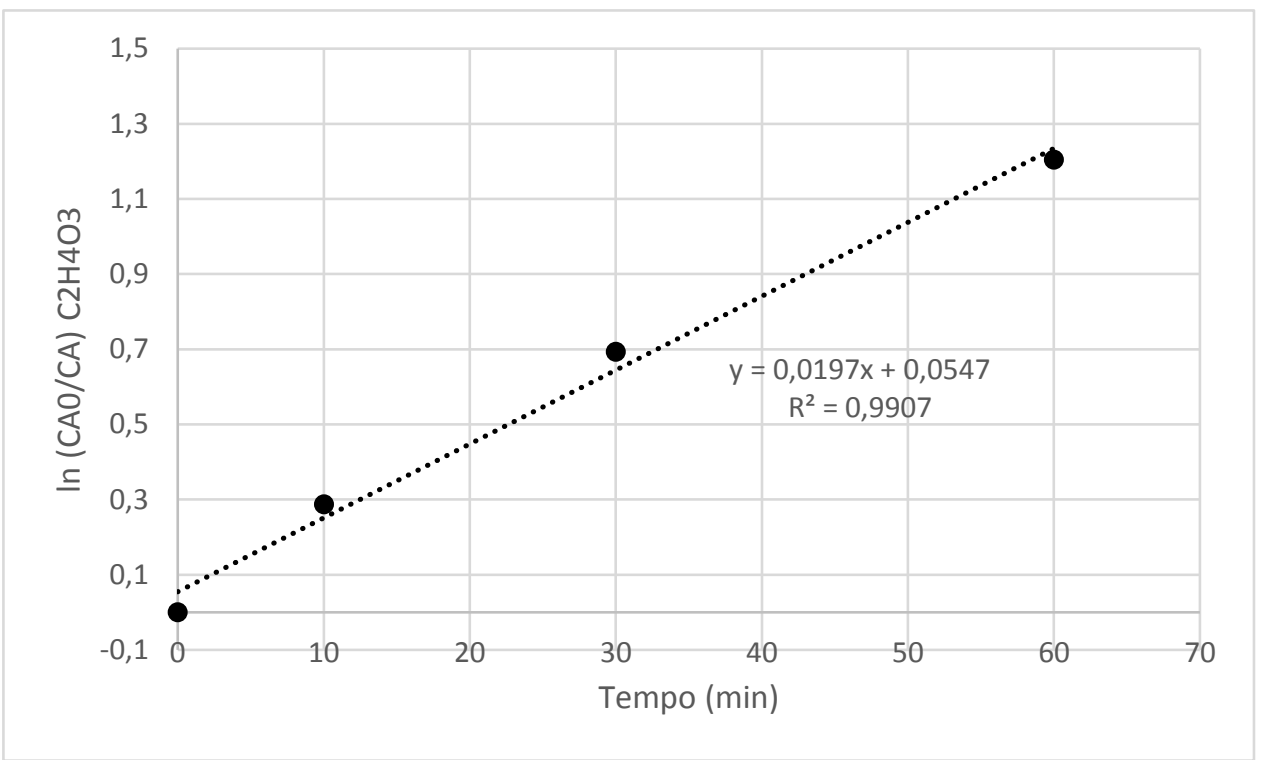

Figura 4.6: Modelo de primeira ordem de reação de decomposição para dosagem inicial de 2,0 $\mathrm{mg} / \mathrm{L}$ de APA em $\mathrm{pH}$ 8,8.

\section{4}

\section{Contagem Bacteriana Inicial das Amostras}

Em todos os experimentos, a contagem de bactérias heterotróficas mesófilas totais foi realizada antes do tratamento com APA, de modo a obter ao final do experimento a comparação da carga microbiana sem o tratamento com biocida e após a sua aplicação, a fim de verificar a eficiência do mesmo. A figura 4.7 ilustra este resultado. 


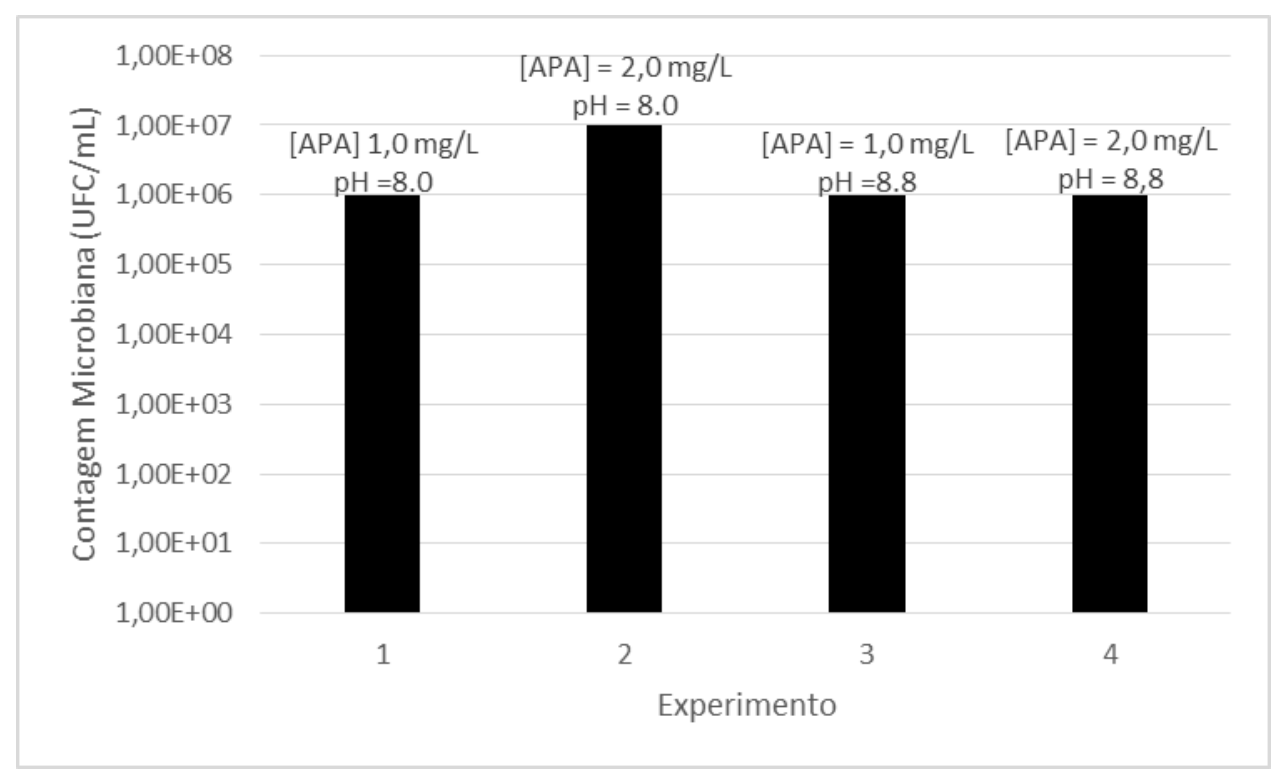

Figura 4.7: Contagem bacteriana antes do tratamento com ácido peracético em cada experimento realizado.

De acordo com a figura 4.5, no primeiro experimento realizado a contagem bacteriana inicial da água foi da ordem de $10^{6} \mathrm{UFC} / \mathrm{mL}$, no segundo de $10^{7}$ $\mathrm{UFC} / \mathrm{mL}$, e nos dois últimos de $10^{6} \mathrm{UFC} / \mathrm{mL}$.

\section{5 \\ Contagem Bacteriana após o Tratamento com Ácido Peracético}

Nesta etapa, a eficiência biocida do APA foi testada nas diferentes condições de estudo. Cada experimento foi realizado em triplicata, ou seja, três béqueres de $2 \mathrm{~L}$ contendo amostras da água foram utilizados para cada condição investigada e os resultados das contagens microbianas para cada amostra, bem como as suas médias, ao longo da campanha de 5 dias são ilustrados nas figuras $4.8,4.9,4.10$ e 4.11 .

Todos os experimentos foram realizados a temperatura de $32{ }^{\circ} \mathrm{C}$ e contagens de bactérias antes da aplicação do APA e após o tratamento em tempos de contato de 5 minutos, 1 hora, 2 horas e 4 horas a cada dia foram executadas. Os resultados das contagens encontram-se no anexo. 
Cabe ressaltar que no primeiro ensaio realizado, com dosagem inicial de APA de $1 \mathrm{mg} / \mathrm{L}$ e pH 8,0, a amostra 2 apresentou contaminação externa, portanto, este resultado foi descartado.

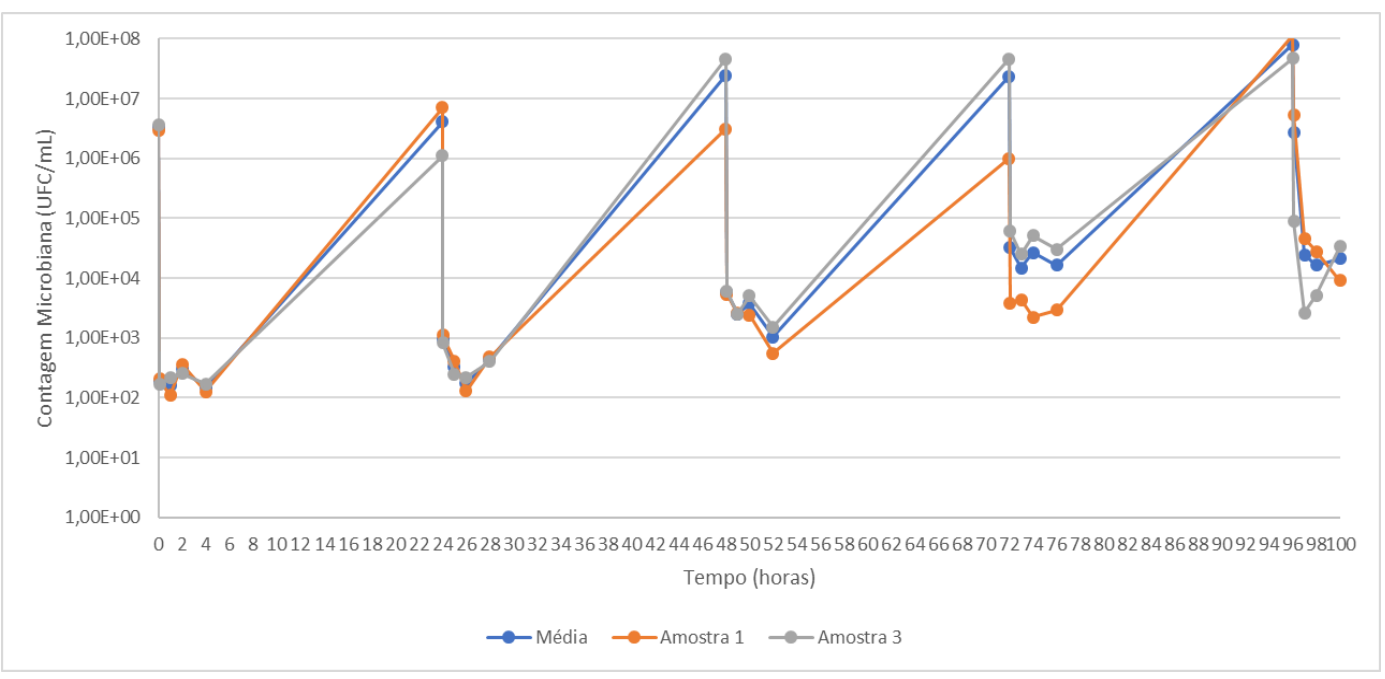

Figura 4.8: Experimento 1 - Efeito do tratamento com 1,0 mg/L de ácido peracético $(\mathrm{pH} 8,0)$ ao longo dos 5 dias na microbiota presente na água de torre de resfriamento.

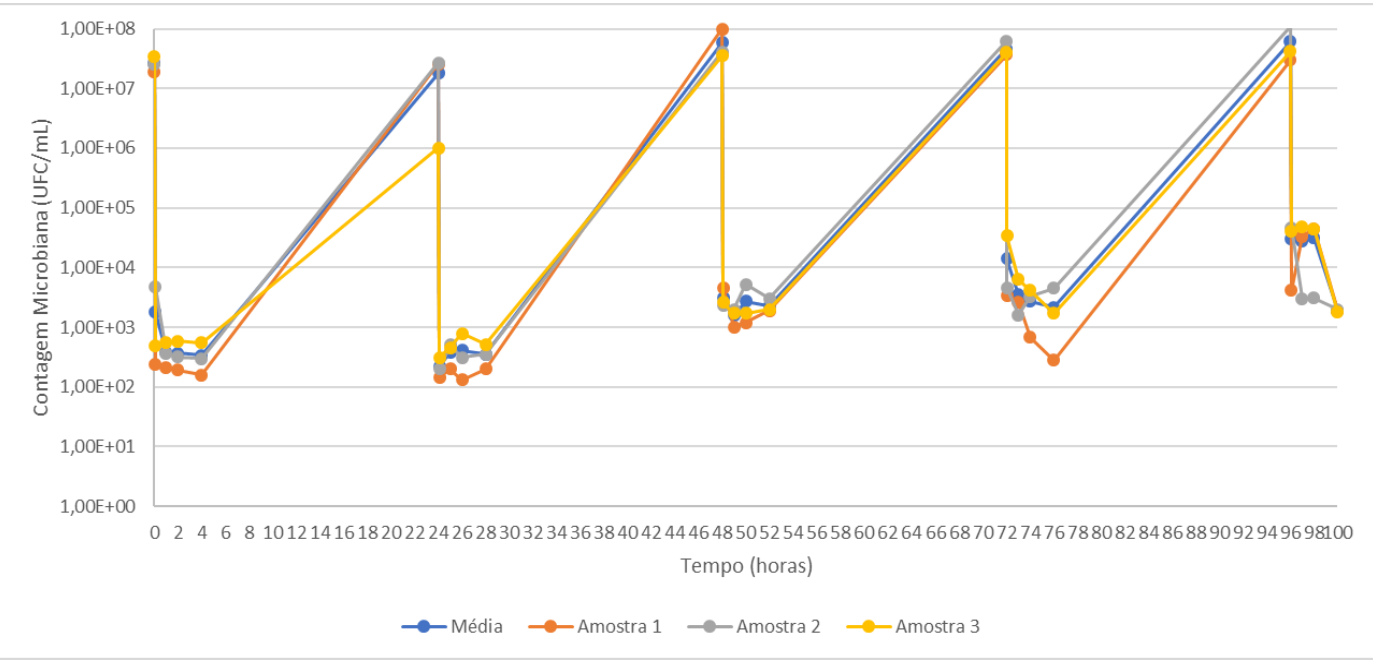

Figura 4.9: Experimento 2 - Efeito do tratamento com 2,0 mg/L de ácido peracético $(\mathrm{pH} \mathrm{8,0)}$ ao longo dos 5 dias na microbiota presente na água de torre de resfriamento. 


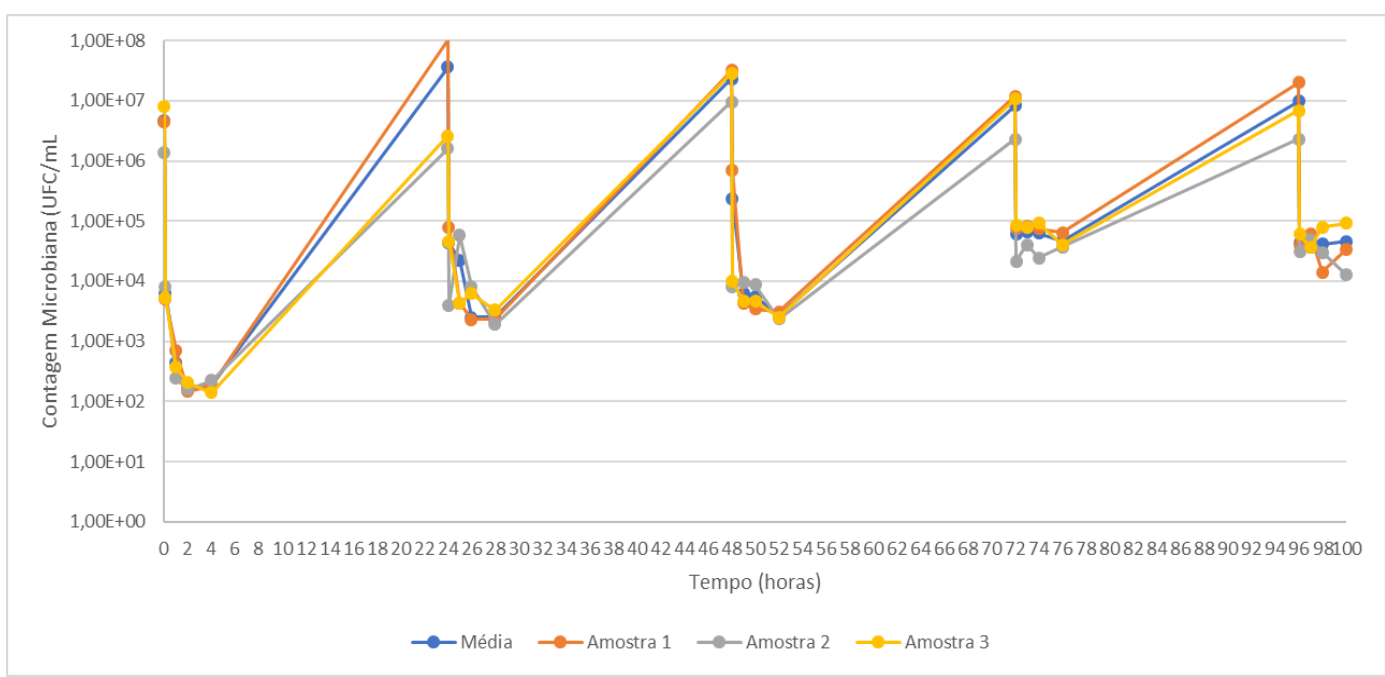

Figura 4.10: Experimento 3 - Efeito do tratamento com 1,0 mg/L de ácido peracético $(\mathrm{pH} 8,8)$ ao longo dos 5 dias na microbiota presente na água de torre de resfriamento.

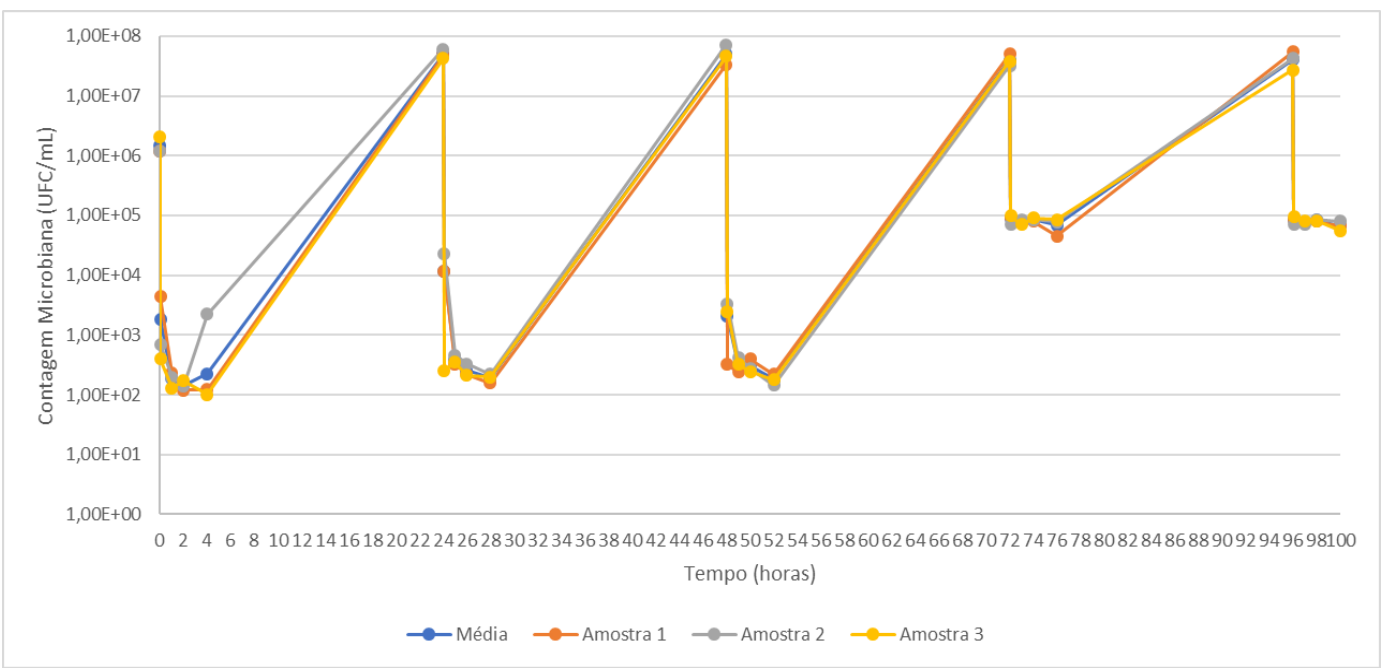

Figura 4.11: Experimento 4 - Efeito do tratamento com 2,0 mg/L de ácido peracético $(\mathrm{pH} \mathrm{8,8)} \mathrm{ao}$ longo dos 5 dias na microbiota presente na água de torre de resfriamento.

De acordo com os resultados ilustrados nas figuras 4.8, 4.9, 4.10 e 4.11, foi possível analisar o comportamento do APA sobre a carga microbiana presente na água de estudo ao longo dos 5 dias de cada experimento. Esta análise foi realizada com base nas contagens médias das três amostras.

No primeiro experimento, com concentração de APA de 1,0 mg/L e pH 8,0, percebe-se que nos três primeiros dias da campanha, houve redução de 4 log na contagem bacteriana após a aplicação do biocida. Nos últimos dois dias, foi 
observado um decaimento de $3 \log$. Em relação ao tempo de contato, houve uma redução de $4 \log \operatorname{logo}$ nos primeiros 5 minutos após a aplicação do biocida, mantendo a faixa de decaimento microbiano nessa ordem por um período de 52 horas. Após esse período até o final de experimento (100 horas de contato do APA com a amostra de água) foi observado uma redução da efetividade do APA, atingindo uma taxa de decaimento microbiano de $3 \mathrm{log}$.

Já no segundo experimento, para concentração de APA de 2,0 mg/L no mesmo valor de $\mathrm{pH}$, nos dois primeiros dias uma redução de 5 log na contagem microbiana foi observada, enquanto nos dois dias posteriores, o decaimento foi de $4 \mathrm{log}$, e por fim, ao final do último dia, o decaimento foi de $3 \log$ Para os diferentes tempos de contato, em 5 minutos de contato do APA com a amostra de água houve uma redução bacteriana de $4 \log$, passando para 5 log após 1 hora de experimento, mantendo-se constante até o tempo de contato de 28 horas. A partir desse período, a redução observada foi de $4 \log$ até 76 horas de contato e de $3 \log$ após as 100 horas da campanha experimental.

Aumentando o valor de $\mathrm{pH}$ para 8,8, o terceiro experimento, com dosagem de 1,0 mg/L do biocida apresentou um comportamento de queda de bactérias de 4 $\log$ nos primeiros três dias. Na sequência da campanha, a eficiência do biocida caiu para 2 log. Assim como nos experimentos anteriores, foi observada uma queda significativa na quantidade de bactérias nos primeiros 5 minutos após a dosagem do APA, com uma redução de 3 log, sendo alcançada uma redução bacteriana de 4 log após 1 hora de contato do biocida com a amostra de água, mantendo-se constante por um período de 54 horas. A redução da efetividade do biocida foi observada a partir deste período, mantendo um decaimento microbiano de 2 log até um tempo de contato de 100 horas.

No último teste realizado nesse mesmo valor de $\mathrm{pH}$ e concentração de 2,0 $\mathrm{mg} / \mathrm{L}$ de APA demonstrou um decaimento microbiano de 4 log no primeiro dia, aumentando para 5 log nos dois dias subsequentes e ao final da campanha experimental a redução foi de $3 \log$. Repetindo a análise realizada nos experimentos anteriores para diferentes tempos de contato, foi observada uma queda bacteriana de $3 \log$ nos primeiros 5 minutos de aplicação do APA, alcançando um decaimento de $4 \log$ a partir de 1 hora de ensaio, mantendo essa faixa constante até 4 horas. Após esse período foi observado uma redução de 5 log até um tempo de contato de 
52 horas. Em seguida, a taxa de queda bacteriana reduziu para 3 log, mantendo-se assim até o final do experimento.

Por fim, pôde-se observar a rápida efetividade do APA na carga microbiana das amostras de água em todos os experimentos.

Para melhor visualização dos comportamentos aqui descritos, as figuras $4.12,4.13,4.14$ e 4.15 apresentam o decaimento microbiano total ao final de cada dia da campanha.

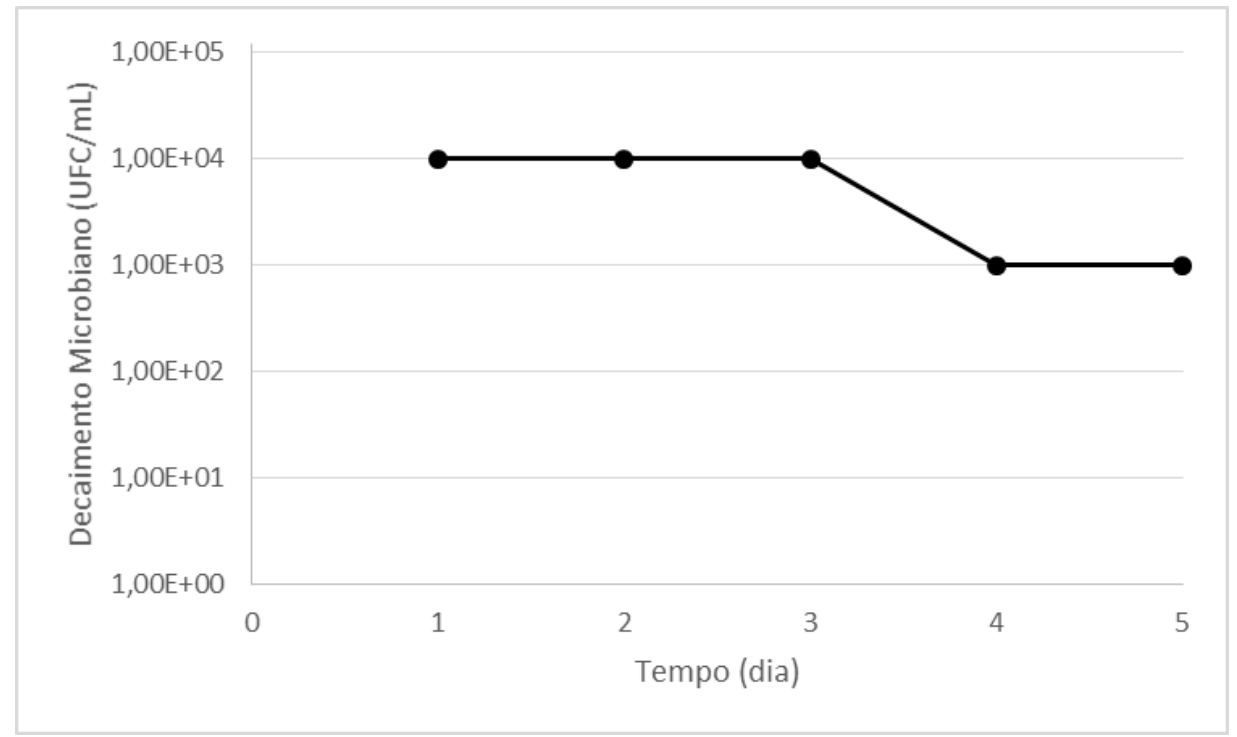

Figura 4.12: Decaimento microbiano total ao final de cada dia ao longo do experimento no tratamento com 1,0 mg/L de ácido peracético $(\mathrm{pH} 8,0)$, com contagem microbiana inicial de $3,35 \mathrm{x}$ $10^{6} \mathrm{UFC} / \mathrm{mL}$.

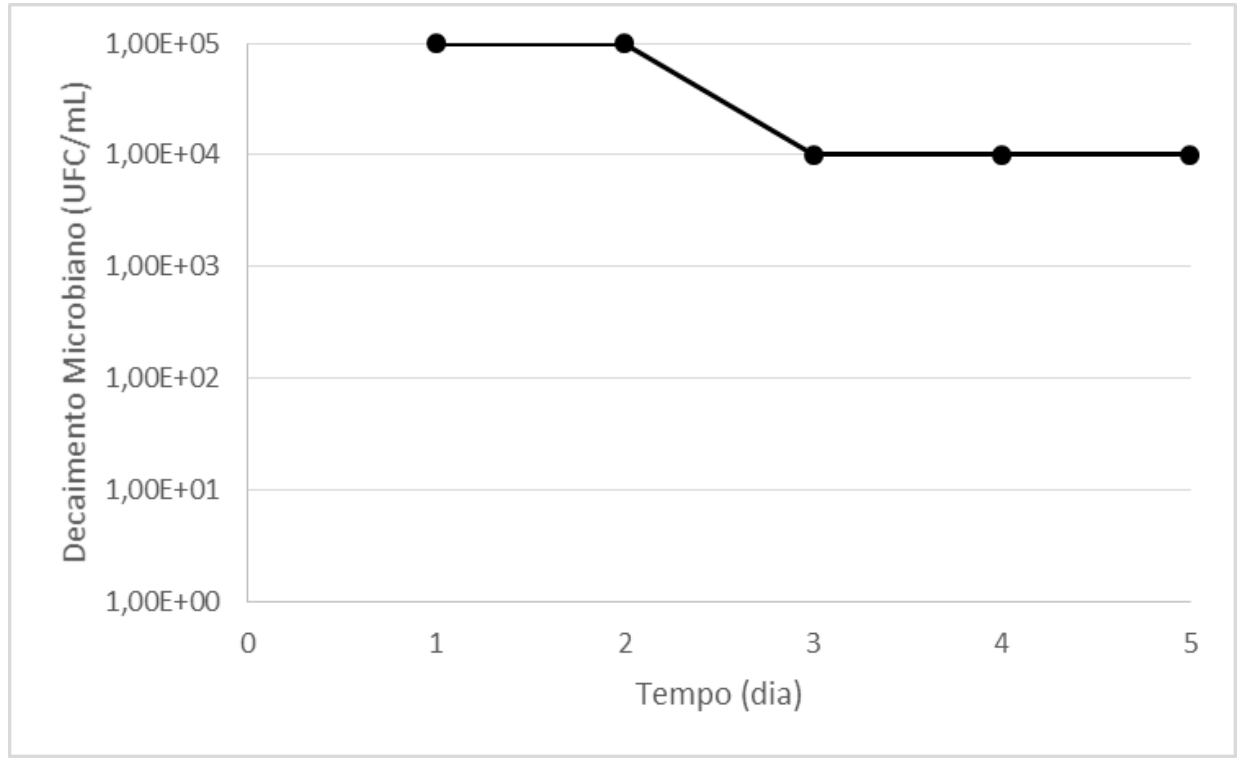

Figura 4.13: Decaimento microbiano total ao final de cada dia ao longo do experimento no tratamento com 2,0 mg/L de ácido peracético $(\mathrm{pH} \mathrm{8,0),} \mathrm{com} \mathrm{contagem} \mathrm{microbiana} \mathrm{inicial} \mathrm{de} 2,62 \mathrm{x}$ $10^{7} \mathrm{UFC} / \mathrm{mL}$. 


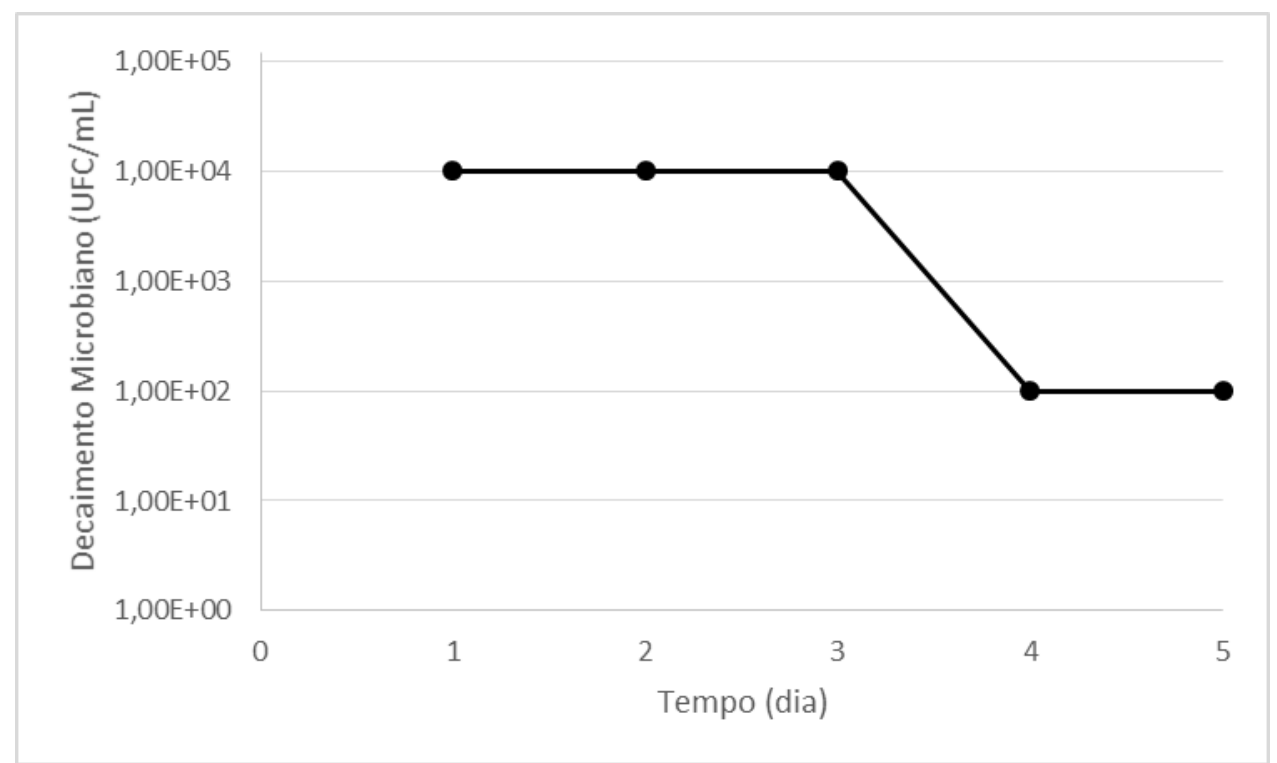

Figura 4.14: Decaimento microbiano total ao final de cada dia ao longo do experimento no tratamento com 1,0 mg/L de ácido peracético $(\mathrm{pH} 8,8)$, com contagem microbiana inicial de $4,7 \mathrm{x}$ $10^{6} \mathrm{UFC} / \mathrm{mL}$.

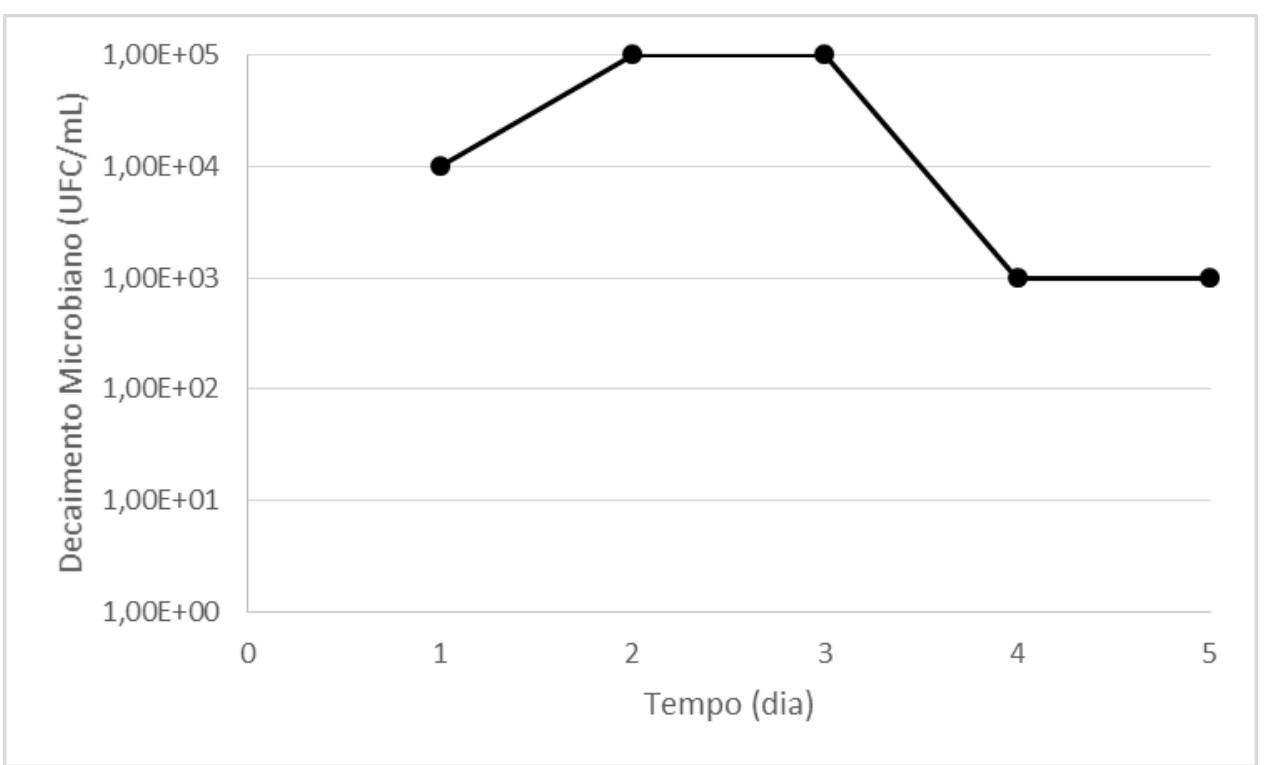

Figura 4.15: Decaimento microbiano total ao final de cada dia ao longo do experimento no tratamentocom 2,0 mg/L de ácido peracético $(\mathrm{pH} 8,8)$, com contagem microbiana inicial de 1,5 $\mathrm{x}$ $10^{6}$.

Em resumo, a figura 4.16 apresenta uma comparação do comportamento dos quatro experimentos quanto ao decaimento microbiano ao final das campanhas de 5 dias. 


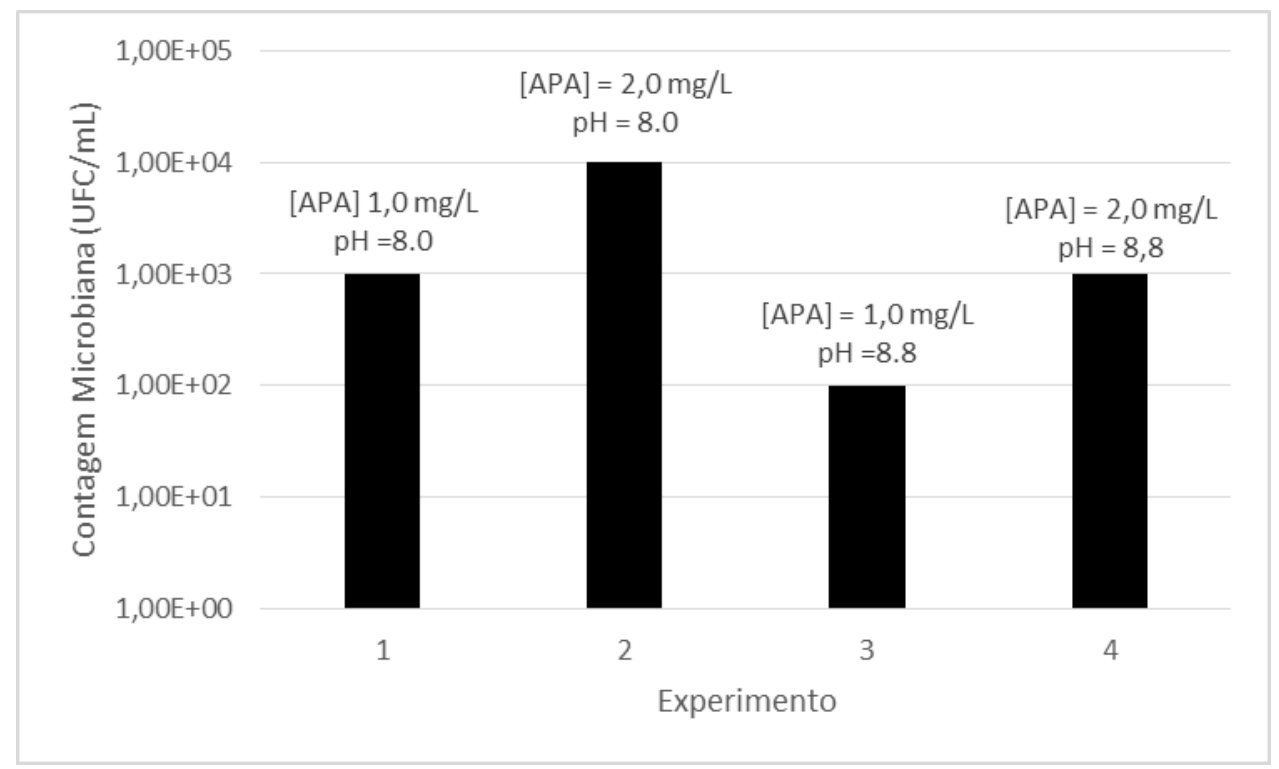

Figura 4.16: Comparação da eficiência do ácido peracético nos quatro experimentos realizados, através do decaimento microbiano total ao final das campanhas de 5 dias.

De acordo com os resultados, foi possível investigar a influência da dosagem do biocida sobre a eficiência no controle microbiano nas amostras estudadas. Nos dois valores de $\mathrm{pH}$ estudados a dosagem de 2,0 mg/L de APA alcançou maior eficiência no controle de microrganismos, em comparação a dosagem de 1,0 mg/L. entretanto, cabe ressaltar, que as duas concentrações foram eficientes, atingindo-se ao final dos 5 dias de campanha um limite aceitável de bactérias adotado pelas indústrias para todos os experimentos.

Além disso, outra vantagem observada do APA foi seu tempo de ação sobre os grupos microbianos presentes na água de estudo, o mesmo foi altamente eficiente em 5 minutos após sua aplicação.

Aslari et al. (1992) avaliaram a concentração bactericida mínima de quatro desinfetantes: APA, peróxido de hidrogênio, formaldeído e cloro, observando que em relação a inativação de E.coli o desempenho do APA não se apresentou dependente do tempo de contato, diferentemente dos outros produtos.

Less et al. (2014) estudaram a comparação do APA e do peróxido de hidrogênio na desinfecção de esgoto sanitário e os resultados demonstraram que o APA foi mais adequado as características do efluente analisado e uma dosagem de $10 \mathrm{mg} / \mathrm{L}$ em tempo de contato de 5 minutos promoveu a redução de $4 \log$ de inativação para E.coli. 
Cavallini et al. (2011) tratou um efluente secundário com dosagem de 10 $\mathrm{mg} / \mathrm{L}$ de APA e alcançou decaimento da carga microbiana de 4 log de coliformes totais e E.coli, em tempo de contato de 20 minutos.

Souza e Daniel (2005) compararam o hipoclorito de sódio e APA na inativação de E.coli, colifagos e C. perfringens e os ensaios com APA apresentaram melhores resultados, com efetiva inativação destes microrganismos. Para 5,0 mg/L de APA, inativações de E.coli maiores que $6 \mathrm{log}$ em tempos de contato de 15 minutos, inativação maior que $5 \log$ de colifagos para tempo de contato de 20 minutos e redução maior que $4 \log$ para C.perfringens em 10 minutos de contato.

Um ponto observado na presente pesquisa e que merece atenção é que a eficiência do APA foi maior nos primeiros dias de ensaio. Ao final das campanhas de 5 dias, uma redução na sua eficiência foi observada. Este fator pode ser atrelado à decomposição do APA na água, que forma ácido acético, aumentando o conteúdo orgânico do meio, fonte de nutrientes para o crescimento de microrganismos, ou a resistência de alguns grupos de bactérias ao agente oxidante.

Além disso, foi possível observar que em todos os experimentos, a carga microbiana aumentou para o ponto inicial durante o período de estocagem noturna da água. Este efeito pode ser justificado pela multiplicação dos microrganismos resistentes ao APA (nas baixas concentrações empregadas) ou a redução se tratou de apenas um efeito bacteriostático (inibição do metabolismo celular e não bactericida), uma vez que a contagem voltava rapidamente a números elevados.

Em relação ao $\mathrm{pH}$, nos meios com $\mathrm{pH} 8,0$ a inativação microbiana foi mais eficiente do que em $\mathrm{pH} 8,8$.

\section{6}

\section{Consumo do Ácido Peracético ao longo dos Experimentos}

Em todos os experimentos, após a dosagem inicial do APA, a concentração do mesmo foi monitorada a cada hora, por um período de 4 horas/dia, e sempre corrigida ao valor inicial aplicado, conforme ilustrado nas figuras 4.17, 4.18, 4.19 e 4.20. De acordo com pesquisas anteriores, o APA se decompõe espontaneamente para produzir ácido acético e oxigênio, de acordo com a reação abaixo (MCFADDEN et al., 2017): 


$$
\mathrm{C}_{2} \mathrm{H}_{4} \mathrm{O}_{3} \rightarrow \mathrm{CH}_{3} \mathrm{COOH}+1 / 2 \mathrm{O}_{2}
$$

A formação de ácido acético a partir da decomposição do APA ao longo dos experimentos pôde ser calculada e é representada pelas figuras 4.21 e 4.22.

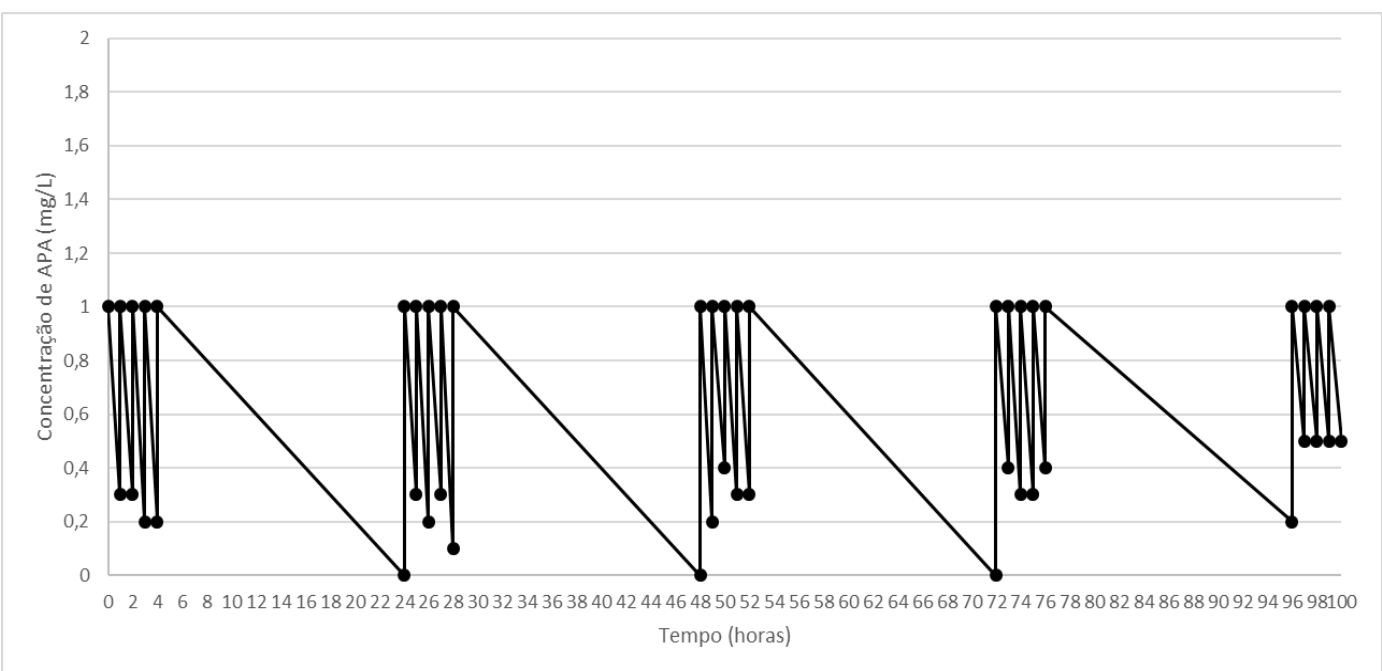

Figura 4.17: Monitoramento da concentração de ácido peracético ao longo de 4 horas/dia nos 5 dias de experimento para dosagem de $1 \mathrm{mg} / \mathrm{L}(\mathrm{pH} \mathrm{8,0)}$.

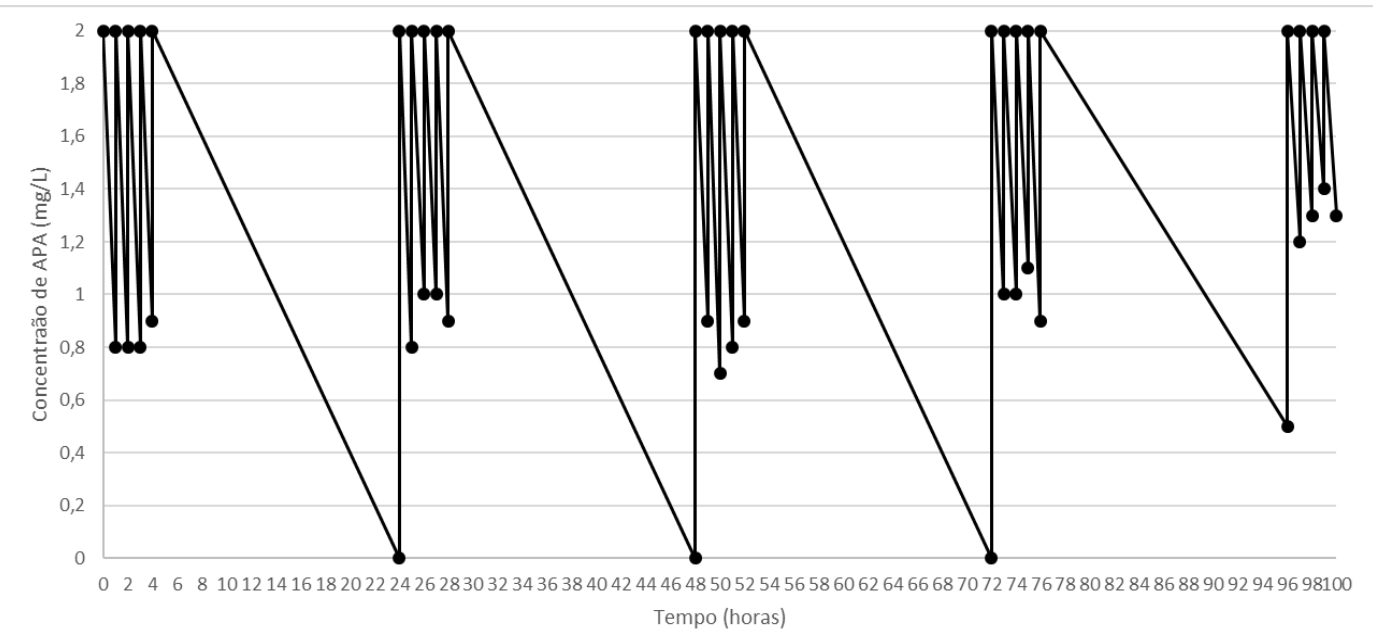

Figura 4.18: Monitoramento da concentração de ácido peracético ao longo de 4 horas/dia nos 5 dias de experimento para dosagem de $2 \mathrm{mg} / \mathrm{L}(\mathrm{pH} 8,0)$. 


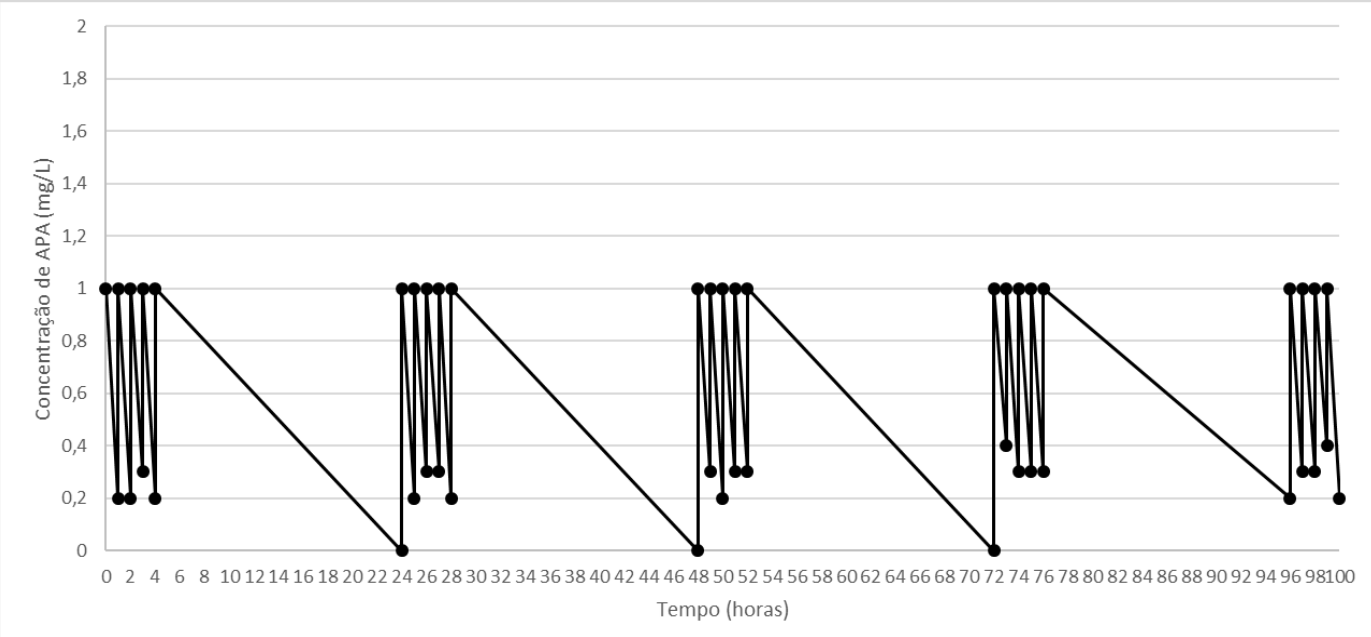

Figura 4.19: Monitoramento da concentração de ácido peracético ao longo de 4 horas/dia nos 5 dias de experimento para dosagem de $1 \mathrm{mg} / \mathrm{L}(\mathrm{pH} 8,8)$.

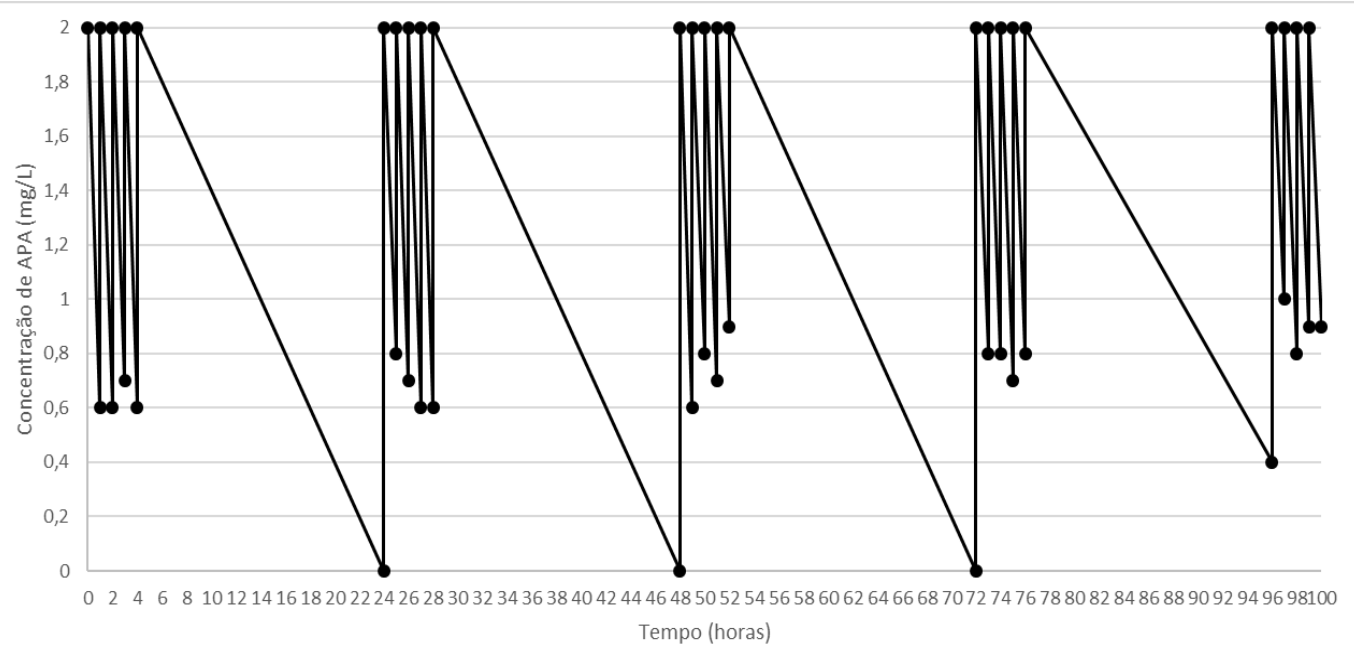

Figura 4.20: Monitoramento da concentração de ácido peracético ao longo de 4 horas/dia nos 5 dias de experimento para dosagem de $2 \mathrm{mg} / \mathrm{L}(\mathrm{pH} 8,8)$. 


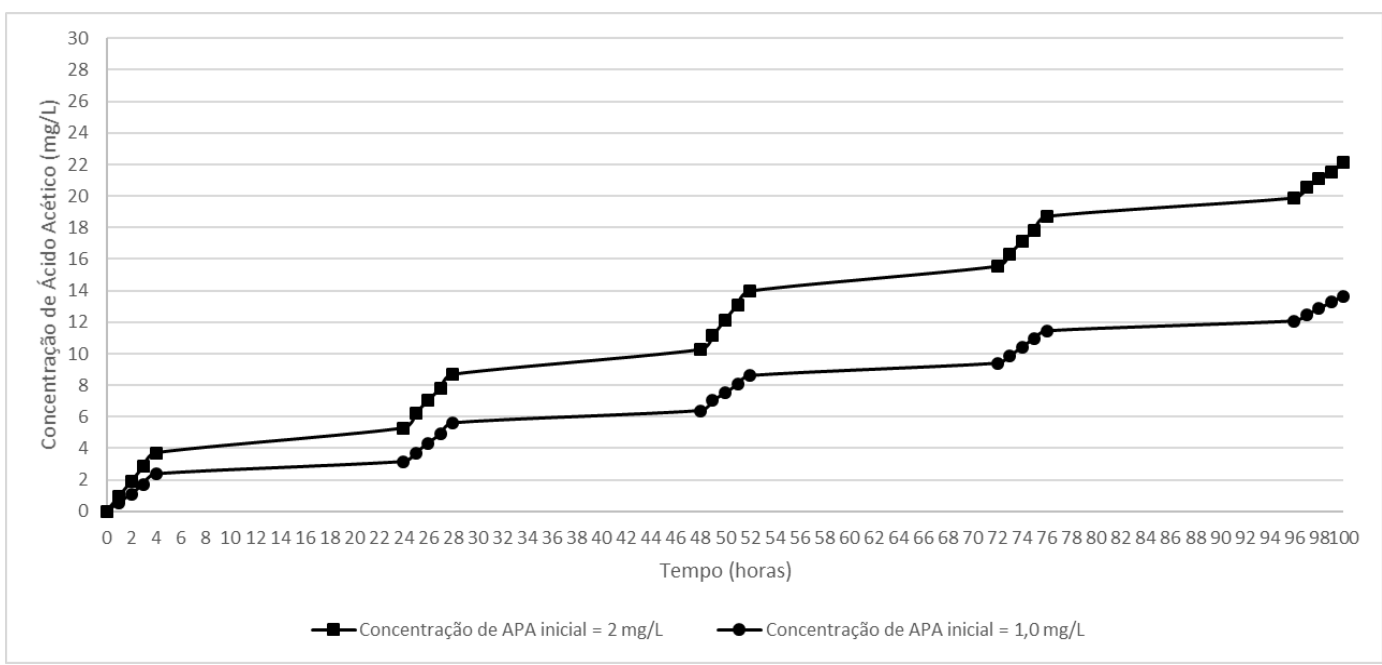

Figura 4.21: Concentração de ácido acético acumulado ao longo dos 5 dias de experimento para dosagens iniciais de ácido peracético de 1,0 mg/L e 2,0 mg/L ( $\mathrm{pH} 8,0)$.

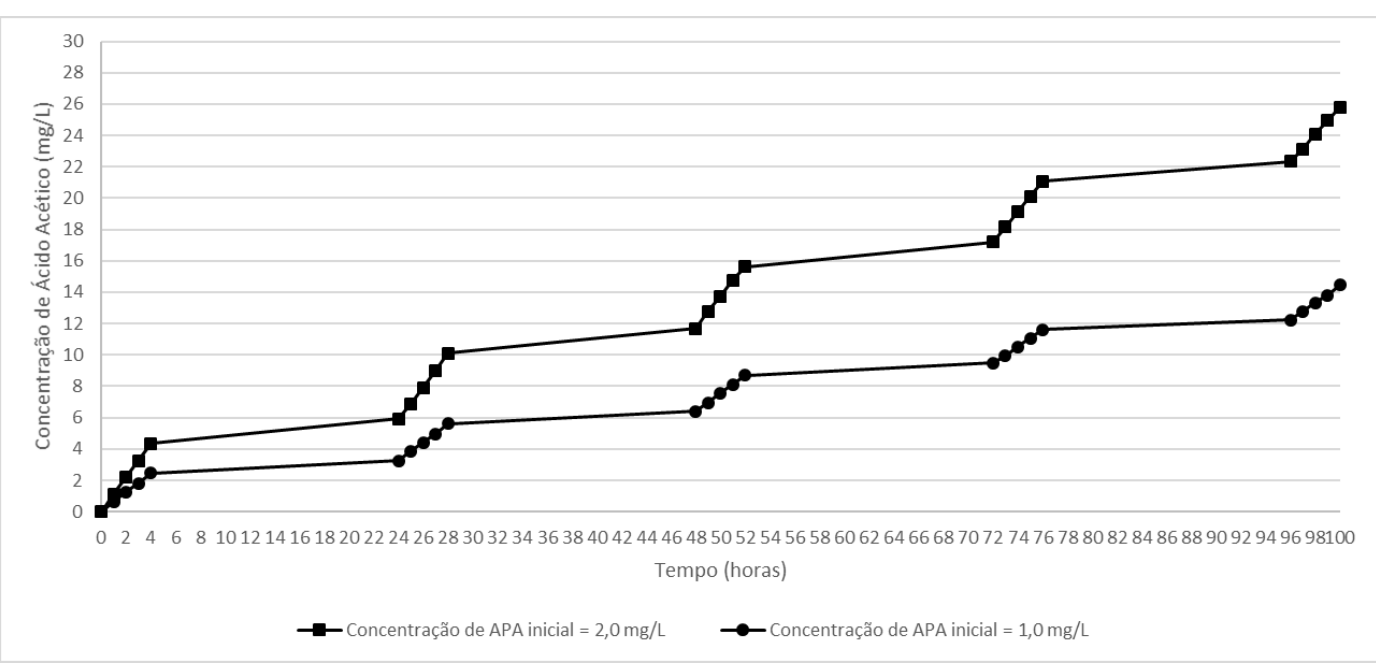

Figura 4.22: Concentração de ácido acético acumulado ao longo dos 5 dias de experimento para dosagens iniciais de ácido peracético de 1,0 mg/L e 2,0 mg/L ( $\mathrm{pH} 8,8)$.

Conforme observado nas figuras 4.21 e 4.22, para o valor de $\mathrm{pH} 8,0$ a concentração de ácido acético acumulado ao final do experimento devido a decomposição espontânea do APA, em que as dosagens iniciais do biocida foram de 1,0 mg/L e $2 \mathrm{mg} / \mathrm{L}$ é de 13,6 mg/L e 22,1 mg/L, respectivamente. Já para o valor de $\mathrm{pH} 8,8$, a concentração de ácido acético obtida foi maior, representando 14,4 $\mathrm{mg} / \mathrm{L}$ e 25,8 mg/L para as mesmas concentrações iniciais de APA.

Considerando pela Tabela 3.1 que a DQO máxima recomendada para água de resfriamento seja de $75 \mathrm{mg} \mathrm{O}_{2} / \mathrm{L}$, sendo que a DQO associada ao ácido acético seja de 1,06 $\mathrm{mg} \mathrm{O}_{2} / \mathrm{L}$ para cada $1 \mathrm{mg} / \mathrm{L}$ de ácido acético, calcula-se que o limite máximo desejável de concentração de ácido acético acumulado será de 70,8mg/L. 
Este valor deve contemplar a soma do ácido acético gerado pela decomposição do APA (figuras 4.21 e 4.22) e a parcela de ácido acético presente na solução-mãe do APA que é adicionado ao longo do tratamento. A tabela 4.1 ilustra a concentração de ácido acético acumulada ao final dos experimentos.

Tabela 4.1: Concentração de ácido acético ao final dos experimentos.

\begin{tabular}{cccc}
\hline Experimento & $\begin{array}{c}{[\mathbf{A A}]} \\
\text { gerado pela } \\
\text { decomposição do } \\
\text { APA (mg/L) }\end{array}$ & $\begin{array}{c}\text { [AA] } \\
\text { dalução-mãe } \\
(\mathbf{m g} / \mathbf{L})\end{array}$ & $\begin{array}{c}\text { [AA]total } \\
(\mathbf{m g} / \mathbf{L})\end{array}$ \\
\hline 1 & 13,6 & 18,8 & 32,4 \\
2 & 22,1 & 31,06 & 53,2 \\
3 & 14,4 & 19,6 & 34 \\
4 & 25,8 & 35,6 & 61,4 \\
\hline
\end{tabular}

Para calcular a concentração de ácido acético gerado pela decomposição do APA, utilizou-se a relação estequiométrica, onde 1 mol de APA equivale a $1 \mathrm{~mol}$ de ácido acético. Utilizando-se o peso molecular dos compostos, tem-se que $76 \mathrm{mg}$ de APA produz $60 \mathrm{mg}$ de AA. Portanto, através das medições da concentração de APA ao longo dos experimentos, foi possível calcular a concentração de ácido acético gerado pela decomposição do biocida. Já para o cálculo da concentração de ácido acético da solução-mãe (15\% APA, $16 \%$ ácido acético e 23\% peróxido de hidrogênio) adicionado nas amostras de água ao longo das campanhas experimentais, tem-se que a cada $1 \mathrm{mg} / \mathrm{L}$ adicionado de APA, adiciona-se também $1,06 \mathrm{mg} / \mathrm{L}$ de ácido acético.

Ao final do ciclo de 5 dias do primeiro experimento ( $\mathrm{pH}$ 8,0 e concentração inicial de APA de 1,0 mg/L), a carga total de APA adicionada na amostra de água da solução-mãe foi de 17,8 mg/L, o que equivale a 18,8 mg/L de ácido acético. Somando o valor da concentração de ácido acético gerado pela decomposição do APA (13,6 mg/L), a concentração total de ácido acético obtido na amostra é de 32,4 $\mathrm{mg} / \mathrm{L}$.

Já no segundo experimento ( $\mathrm{pH}$ 8,0 e concentração inicial de APA de 2,0 $\mathrm{mg} / \mathrm{L}$ ), a carga total de APA da solução-mãe adicionada foi de $29,3 \mathrm{mg} / \mathrm{L}$, o que equivale a 31,06 mg/L de ácido acético. Somando o valor da concentração de ácido acético gerado pela decomposição do APA $(22,1 \mathrm{mg} / \mathrm{L})$, a concentração total de ácido acético foi de 53,2 mg/L. 
No terceiro experimento ( $\mathrm{pH}$ 8,8 e concentração inicial de APA de 1,0 $\mathrm{mg} / \mathrm{L}$ ), a carga total de APA da solução-mãe adicionada foi de $18,5 \mathrm{mg} / \mathrm{L}$, o que equivale a 19,6 mg/L de ácido acético. Com a adição da concentração de ácido acético gerado através da decomposição do APA (14,4 mg/L), a concentração total de ácido acético ao final da campanha é de $34 \mathrm{mg} / \mathrm{L}$.

Por fim, no quarto experimento (pH 8,8 e concentração inicial de APA de 2,0 mg/L), a carga total de APA da solução-mãe adicionada foi de 33,6 mg/L, o que equivale a 35,6 mg/L de ácido acético. Sendo assim, adicionando 25,8 mg/L de ácido acético gerado pela decomposição do APA, obtém-se uma concentração total de $61,4 \mathrm{mg} / \mathrm{L}$.

Note-se que esses são valores referentes à aplicação do APA em apenas 4 horas por dia. Para, por exemplo, calcular o consumo mensal de APA em um circuito contendo, por exemplo, $10000 \mathrm{~m}^{3}$ de volume de água em $\mathrm{pH} 8$ mantendose por $4 \mathrm{~h} / \mathrm{d}$ a $[\mathrm{APA}]=1,0 \mathrm{mg} / \mathrm{L}$, o consumo mensal será de $1068 \mathrm{~kg}$ de APA a $100 \%$ de concentração, o que é equivalente a 7,12 t de APA a $15 \%$.

A formação de ácido acético propicia o aumento de carbono orgânico total na água, ou seja, a elevação da carga orgânica, podendo acarretar no aumento de microrganismos (KITIS, 2003). Este fenômeno pode explicar o motivo pelo qual os experimentos realizados nas amostras de água com $\mathrm{pH}$ 8,0 foram mais eficientes que em $\mathrm{pH} 8,8$, visto que a taxa de decomposição do APA nos experimentos realizados em $\mathrm{pH}$ 8,0 é menor que em $\mathrm{pH} 8,8$, e consequentemente, a taxa de formação de ácido acético também é menor. Além disso, quando o pH da solução se eleva para valores acima de 8,2, a reação de hidrólise do APA também acontece, produzindo íons peracetato e acetato. Estes íons formados possuem capacidade de desinfecção mínima e a eficiência do APA é reduzida (MCFADDEN, 2017), quanto mais se distancia do $\mathrm{pH} 8,2$.

A influência do material orgânico sobre a eficácia do APA foi relatada em diversos estudos. Koivunem e Heinonen-Tanski (2005) avaliaram a eficiência do APA em efluentes primários, secundários e terciários e os resultados mostraram que no efluente primário a eficiência do biocida diminui, visto que o grau de material orgânico, microrganismos e sólidos suspensos são mais altos.

Falsanisi et al. (2006) utilizaram o APA para tratamento no efluente de uma estação de tratamento de esgoto em uma cidade da Itália, com objetivo de sua reutilização para agricultura. Para atingir o limite de E.coli permitido para reuso na 
agricultura no país, a dosagem ótima do biocida para tratamento do efluente secundário foi de $4 \mathrm{mg} / \mathrm{L}$, já para o efluente primário essa dosagem aumentou para $31 \mathrm{mg} / \mathrm{L}$, os dois com tempo de contato de 40 minutos.

Apesar do tratamento com APA ser mais eficaz em meios com baixo teor de matéria orgânica, Souza (2006) obteve resultados positivos para a aplicação do APA na inativação de diferentes grupos microbianos em meios com alta concentração orgânica.

Uma das vantagens do APA em relação ao cloro é que após sua reação com águas residuais ou matéria orgânica, produz-se pouco ou nenhum subproduto tóxico (BALDRY E FRASER, 1988; MONARCA et al., 2002).

\section{7}

\section{Influência das Características da Água de Estudo na Ação Biocida do Ácido Peracético}

Os parâmetros físico-químicos das amostras de água listados na tabela 3.1 podem propiciar o crescimento de microrganismos e interferir na efetividade do biocida.

A condutividade é a capacidade da água de conduzir corrente elétrica, sendo determinada pela presença de substâncias dissolvidas que se dissociam em cátions e ânions, permitindo dessa forma estimar a quantidade de sais dissolvidos existentes na água e representando uma medida indireta da concentração de poluentes, aumentando a possibilidade de contaminação da água (PERES, 2006).

A salinidade também pode afetar a velocidade de decomposição do APA. De acordo com Kunigk et al. (2008) quanto maior este parâmetro, maior será a velocidade de decomposição, e consequentemente, o aumento de carga orgânica, podendo propiciar o surgimento de novos grupos microbianos.

Por fim, a DQO é uma medida direta da carga orgânica da água e, portanto, deve ser analisada e monitorada em águas de resfriamento. 


\subsection{Grupos de Microrganismos Presentes nas Amostras de Água}

A modificação dos gêneros e espécies de bactérias cultiváveis prevalentes na água antes e depois do tratamento com APA foi observada, conforme apresentado na tabela 4.2.

Tabela 4.2: Espécies de bactérias presentes na água antes e depois do tratamento com ácido peracético.

\begin{tabular}{cc}
\hline Antes do Tratamento & Depois do Tratamento \\
\hline Staphylococcus saprophyticus & Rhizobium radiobacter \\
Staphylococcus warneri & Bacillus subtilis \\
Pseudomonas aeruginosa & Sttneotrothomonas maltophlia \\
Pseudomonas anguilliseptica & Acinetobacter radioresistens \\
Pseudomonas alcaliphila & Pseudomonas alcaligeneses \\
Bacillus cereus & Bacillus cereus \\
Bacillus arsenicus & \\
Bacillus subtilis & \\
Serratia rubidaea & \\
Burkholderia pyrrocinia & \\
Burkholderia cenocepacia & \\
Burkholderia cepacia &
\end{tabular}

Conforme mostrado na tabela 4.2, a água sem tratamento biocida apresentou maior diversidade de espécies bacterianas. Após o tratamento com APA, alguns grupos continuaram sendo observados na água, dentre eles: Rhizobium radiobacter, Bacillus subtilis e Bacillus cereus; e novas espécies apareceram, tais como: Stenotrophomonas maltophilia, Acinetobacter radioresistens, Pseudomonas alcaligeneses e Pseudomonas stutzeri. 
Conforme exposto acima, na água natural sem dosagem do biocida, foram encontradas principalmente bactérias dos gêneros Pseudomonas e Bacillus. Este resultado está de acordo com o que já foi relatado por diversos estudos. Estes gêneros são comuns em sistemas de resfriamento e são responsáveis pela formação de biofilme, podendo reduzir a eficiência da transferência de calor e acelerar processos corrosivos. Dentre as espécies de Pseudomonas, as Pseudomonas aeruginosa são as mais comuns nesse tipo de sistema e o APA foi altamente eficiente sobre esse grupo bacteriano, não sendo constatada sua presença ao final do tratamento. Este resultado também foi alcançado por Martín-Espada (2013), em seus experimentos o biocida alcançou a eficácia de $100 \%$ de controle sobre essa espécie de bactéria.

Já a sobrevivência de certas espécies na água após o tratamento pode ser explicada pela resistência que os microrganismos adquiriram contra o agente químico, ou aqueles que são resistências ao biocida aplicado podem ter sobrevivido e se multiplicado (SUZUKI, 1999). A continuidade da presença de espécies de Bacillus na água após o tratamento químico pode ser explicada pela resistência que estas apresentam ao biocida, que apesar de eficiente, não foi suficiente para disseminação completa das mesmas. Quando as células de certas bactérias Grampositivas, como Bacillus e Clostridium, encontram-se em condições de estresse ambiental, como a privação de nutrientes, elas formam uma estrutura dormente denominada esporo (LEGGETT, 2014). Esporos bacterianos podem sobreviver neste estado inativo por anos (KENNEDY, 1994). Dessa forma, diante do desafio de sobreviver a períodos prolongados de dormência, os esporos desenvolvem muitos mecanismos para se proteger de danos, tornando-se altamente resistentes a muitos tratamentos antimicrobianos. Os esporos possuem adaptações específicas para minimizar os danos sofridos, incluindo os seus revestimentos externos que têm demonstrado fornecer uma resistência significativa contra muitos agentes oxidantes, um baixo teor de água no núcleo, o que contribuí para resistência do esporo a alguns produtos químicos, e pequenas proteínas de ácido solúveis de esporos (PPASs) que satura o DNA do esporo proporcionando proteção contra alguns produtos químicos prejudiciais ao DNA, radiação UV e tratamentos térmicos (LEGGET, 2014).

O surgimento de novas espécies na água ao longo dos experimentos, que não estavam presentes antes do tratamento com biocida, pode ser relacionado a 
decomposição acelerada do APA na água de estudo, que ao formar ácido acético, aumenta a carga orgânica, que acaba servindo de alimentos para as bactérias e podem servir para o recrescimento microbiano (LAZAROVA et al., 1998 apud CAVALLINI et al., 2012). Conforme já exposto no presente trabalho em itens anteriores, existem diversos estudos que constatam que a concentração e origem da matéria orgânica na água influenciam na taxa de decomposição e efetividade do biocida. 


\section{5.}

\section{Conclusões e Sugestões para Trabalhos Futuros}

\section{1}

\section{Conclusões}

Como conclusão do presente trabalho, pode-se destacar que baixas concentrações ( 1 e $2 \mathrm{mg} / \mathrm{L}$ ) de APA foram suficientes para alcançar boa eficiência biocida sobre a redução de bactérias heterotróficas mesófilas totais em água de torre de resfriamento, mantendo o seu valor abaixo do limite máximo recomendado de $10^{4} \mathrm{UFC} / \mathrm{mL}$.

Houve maior eficiência, cerca de 10 vezes maior, quando $2,0 \mathrm{mgL}^{-1}$ de APA foi aplicado comparado à concentração de $1,0 \mathrm{mg} / \mathrm{L}$.

Foi observado que o tempo de contato de 5 minutos do biocida com a colônia de bactérias foi suficiente para reduzir a contagem bacteriana em cada condição testada.

O APA foi eficiente nos dois valores de $\mathrm{pH}$ estudados $(8,0$ e 8,8$)$, sendo que seu poder bactericida foi dez vezes superior em $\mathrm{pH} 8,0$.

A eficácia do APA como biocida nos primeiros dias de cada campanha, foi superior, tendo seu efeito reduzido a partir do terceiro dia de cada campanha experimental.

O consumo de APA nas condições estudadas em unidades de g de PAA por $\mathrm{m}^{3}$ por hora de água tratada mostrou-se fortemente dependente da concentração de APA que se deseja manter na água sob tratamento, tendo sido: em [APA] $=1,0$ $\mathrm{mg} / \mathrm{L}$ e pH 8 igual a $0,183 \mathrm{~g} /\left(\mathrm{m}^{3} \mathrm{~h}\right)$; em [APA] $=2,0 \mathrm{mg} / \mathrm{L}$ e $\mathrm{pH} 8$ igual a 0,300 $\mathrm{g} /\left(\mathrm{m}^{3} \mathrm{~h}\right) ;$ em $[$ APA $]=1,0 \mathrm{mg} / \mathrm{L}$ e $\mathrm{pH}=8,8$ igual a $0,193 \mathrm{~g} /\left(\mathrm{m}^{3} \mathrm{~h}\right) ;$ em $[$ APA $]=2,0$ $\mathrm{mg} / \mathrm{L}$ e $\mathrm{pH}=8,8$ igual a $0,347 \mathrm{~g} /\left(\mathrm{m}^{3} \mathrm{~h}\right)$. Note-se que esses são valores referentes a aplicação do APA em apenas 4 horas por dia.

A quantidade de espécies bacterianas encontrada na água natural, ou seja, sem o tratamento biocida, foi superior ao encontrado ao final das campanhas experimentais, demonstrando a efetividade do APA sobre diversas espécies. Além 
disso, ao final dos experimentos, foram observadas novas espécies e gêneros de bactérias nas amostras de água.

Visto os resultados encontrados, pode-se sustentar que a utilização do APA no controle da carga microbiana em torres de resfriamento pode vir a se tornar competitivo como alternativa ao cloro.

Porém, outras questões devem ser avaliadas, entre elas o seu potencial corrosivo e seu poder biocida sobre as bactérias sésseis, que são as responsáveis pela formação do biofilme.

\section{2}

\section{Sugestões Para Trabalhos Futuros}

Avaliar as taxas de corrosão do APA em diferentes metais;

Avaliar o desempenho sobre a carga de microrganismos, bem como as taxas de corrosão, utilizando-se concentrações menores que 1,0 mg/L de APA;

Avaliar a eficiência da aplicação do APA em conjunto com outro biocida no controle microbiano, de forma que a alternância entre os dois impeça a sobrevivência de bactérias resistentes ao APA, ou que bactérias desenvolvam resistência ao produto;

Estudar a ação do APA em uma diversidade mais ampla de microrganismos, como as bactérias sésseis, que estão diretamente relacionadas com o desenvolvimento de biofilmes e corrosão;

Estudar a comparação do efeito biocida do cloro e do APA, bem como avaliar os custos envolvidos dos dois produtos;

Avaliar o comportamento do APA em campanhas de duração superiores a 5 dias;

Monitorar o surgimento de Legionella, grupo de bactérias Gram-negativas comum em águas de torres de resfriamento. 


\section{Referências bibliográficas}

ABNT. Associação Brasileira de Normas Técnicas. NBR 6111:2013. Torres de Resfriamento de Água. Mar. 2013.

ALASRI, A.; ROQUES, C.; MICHEL, G.; CABASSUD, C.; APTEL, P. Bactericidal properties of peracetic acid and hydrogen peroxide, alone and in combination, and chlorine and formaldehyde against bacterial water strains. Canadian Journal of Microbiology, Ottawa, v. 38, n. 7, p. 635 - 643, 1992.

APHA (1998). Standard Methods for the Examination of Water and Wastewater. American Public Health Association American Water Works Association, Water Environmental Federation, 20 ${ }^{\text {th }}$ ed. Washington.

BALDRY, M. G. C.; FRASER, J. A. L. Disinfection with Peroxygens. In: PAYNE, K. R. (Ed.). Industrial biocides. Nova York: John Wiley \& Sons, 1988. p. 91-116.

BALDRY, M. G. C.; CAVADORE, A.; FRENCH, M. S; MASSA, G.; RODRIGUES, L. M.; SCHIRCH, P. F. T.; THREADGOLD, T. L. Effluent disinfection in warm climates with peracetic acid. Water Science and Technology, Oxford. v. 31, n. 5/6, p. 161 - 164, 1995.

BRIDIER, A; BRIANDET, R; THOMAS, V; et. al. Resistance of Bacterial Biofilms to Disinfectants: a review. Biofouling 2011; 27:1017-1032.

CAVAllini, G. S. Estudo do Ácido Peracético na Desinfecção de Esgoto Sanitário: Influência das Características Físico-Químicas do Efluente, Determinação de Concentração Residual e Cinética de Degradação. 2011. 88 p. Dissertação (Mestrado em Química Aplicada) - Universidade Estadual de Ponta Grossa. Ponta Grossa. 
CAVALLINI, G. S.; CAMPOS, S. X.; SOUZA, J. B; VIDAL, C. M. S. Utilização do Ácido Peracético na Desinfecção de Esgoto Sanitário: Uma Revisão. Seminário: Ciências Exatas e Tecnológicas, Londrina. v. 33, n. 1, p. 27 - 40, 2012.

CERETTA, R. A. Avaliação da Eficiência do Ácido Peracético na Esterilização de Equipamentos Odontológicos. Dissertação (Mestrado em Ciências da Saúde). Universidade do Extremo Sul Catarinense, Criciúma (SC), 2008.

ClOETE, T. E.; JACOBS, L.; BROZEL, V. S. The Chemical Control of Biofouling in Industrial Water Systems. Biodegradation. v 9, 23 - 37, 1998.

CREBELLI, R.; CONTI, L.; MONARCA, D.; FERETTI, D.; ZERBINI, I.; ZANI, E. V.; CUTILli, D.; OTTAVIANI, M. Genotoxicity of the disinfection byproducts resulting from peracetic acid - or hypochlorite - disinfected sewage wastewater. Water Research, Oxford, v. 39, n. 6, p. $1105-1113,2005$.

DANIEL, L. A.; BRANDÃO, C. C. S.; GUIMARÃES, J. R. et al. Métodos Alternativos para Desinfecção de Águas de Abastecimento. Engenharia Sanitária e Ambiental. ABES. RJ. v.5, n. 1 e n. 2, p. 41, 2000.

DAnTAS, E. V. Tratamento de Água de Refrigeração e Caldeiras. Rio de Janeiro: Ecolab, 1988. 370 p.

DI PIPPO, F; DI GREGORIO, L; CONGESTRI, R; TANDOI, V; ROSSETTI, S. Biofilm Growth and Control in Cooling Water Industrial Systems. FEMS Microbiol. Ecol. 94 (2018).

FALSANISI, D.; GEHR, R.; SANTORO, D.; DELL'ERBA, A.; NOTARNICOLA, M.; LIBERTI, L. Kinetics of PAA Demand and its Implications on Disinfection of Wastewaters. Water Quality Research Journal of Canada, Burlington, v. 41, n. 4, p. 398-409, 2006.

GENTIL, V. Corrosão. 3a Edição. Editora LTC, 368p, 2007. 
HANNAN, S; READY, D; JASNI, A.S; ET. AL. Transfer of antibiotic resistance by transformation with eDNA within oral biofilms. FEMS Immunol Med Microbiol 2010; 59:345-349.

HEINZEL, M. Phenomena of Biocide Resistance in Microorganisms. Int Biodeterior Biodegrad 1998; 41:225-34.

DI GREGORIO, L; TANDOI, V.; CONGESTRI, R.; ROSSETI, S.; DI PIPPO, F. Unravelling the Core Microbiome of Biofilms in Cooling Tower Systems. The Journal of Bioadhesion and Biofilm Research, Biofouling 2017; 14: 1-14.

KELLY, B.G; VESPERMANN, A; BOLTON, D.J. Horizontal Gene Transfer of Virulence Determinants in Selected Bacterial Foodborne Pathogens. Food Chem Toxicol 2009;.47:969-977.

KENNEDY, M. J; READER, S. L.; SWIERCZYNSKI, L. M. Preservation Records of Microrrganisms - Evidence of the Tenacity of Life. Microbiology, 140: 2513 - 2529, 1994.

KITIS, M. Disinfection of Wastewater with Peracetic Acid: a review. Environment International, New York., v. 30, n. 1, p. 47 - 55, 2004.

KOIVUNEM, J.; HEINONEN-TANSKI, H. Peracetic Acid (PAA) Disinfection of Primary, Secondary and Tertiary Treated Municipal Wastewaters. Water Research, New York, v. 39, n. 18, p. 4445-4453, 2005.

KUNIGK, L.; SILVA, S. M.; JURKIEWICZ. The Influence of Temperature and Organic Matter on the Decomposition Kinectics of Peracetic Acid in Aqueous Solutions. Latin American Applied Research. 42: 291 - 297, 2012.

LEGGETT, M. J.; SCHWARZ, J. S.; BURKE, P. A.; MCDONNELL, DENYER, S. P.; MAILLARD, J. Y. Resistance to and Killing by Sporicidal Microbicide Peracetic Acid. Journal of Antimicrobial Chemotheraphy. 70 (3), p. 773 - 779, 2014. 
LESS, D. F. S.; LESS. F. R.; BONFIM. L. T.; CAVALLINI, G. S.; VIDAL, C. M. S. Estudo Comparativo do Uso de Ácido Peracético e Peróxido de Hidrogênio para Desinfecção de Esgoto Sanitário. v. 11, n. 2, p. 028 - 037, 2014.

MACHADO, L. P. Reúso de Esgotos Sanitários Tratados para Fins de Água de Reposição em Torres de Resfriamento. Dissertação (Mestrado em Engenharia Ambiental). UERJ. RJ, 181 p, 2004.

MAINIER, F. B.; SANDRES, G. C.; TAVARES, S. S. M. Corrosão por Sulfeto de Hidrogênio $\left(\mathrm{H}_{2} \mathrm{~S}\right)$ e suas Implicações no Meio Ambiente e na Segurança Industrial. In: $8^{\circ}$ Congresso Ibero Americano de Engenharia Mecânica, Cusco, 2007.

MARTÍN-ESPADA, M. C.; D’ORS, A.; BARTOLOMÉ, M. C.; PEREIRA, M.; SÁNCHEZ-FORTÚN, S. Peracetic Acid Disinfectant Efficacy against Pseudomonas aeruginosa Biofilms on Polystyrene Surfaces and Comparison between Methods to Measure it. Food Science and Technology, v. 56, p. 58 - 61, 2014.

MCFADDEN, M.; LOCONSOLE, J.; SCHOCKLING, A. J.; NERENBERG, R.; PAVISSICH, J. P. Comparing Peracetic Acid and Hypochlorite for Disinfection of Combined Sewer Overflows: Effects of suspended-solids and pH. Science of the Total Environment, v. 599 - 600, p. 533 - 539, 2017.

MELO, I. R. Formação de Biofilmes e Biocorrosão em Aço Carbono AISI 1020 Exposto em Sistema Aquoso Contendo Diferentes Teores de Diesel/Biodiesel. Tese (Doutorado em Tecnologia de Processos Químicos e Bioquímicos). Universidade Federal do Rio de Janeiro, 107 p, 2012.

MONARCA S.; RICHARDSON S. D.; FERETTI, D.; GROTTOLO, M; THRUSTON, A. D.; ZANI, C.; et al. Mutagenicity and Disinfection by-products in Surface Drinking Water Disinfected with Peracetic Acid. Environ Toxicol Chem, 21: $309-318,2002$. 
PAL, C; BENGTSSON-PALME, J; KRISTIANSSON, E; et. al. Co-occurrence of Resistance Genes to Antibiotics, Biocides and Metals Reveals Novel Insights into their Co-Selection Potential. BMC Genomics 2015; 16:964.

PEREIRA, R. P. A; PEPLIES, J; HÖFLE, M.G; et. al. Bacterial Community Dynamics in a Cooling Tower with Emphasis on Pathogenic Bacteria and Legionella Species using universal and genus-specific deep sequencing. Water Res 2017; 122:363-376.

PERES, F. A. S. Tratamento de Águas de Resfriamento com Peróxido de Hidrogênio. Dissertação (Mestrado em Ciência dos Materiais e Metalurgia). PUC RIO, Rio de Janeiro, 94 p, 2006.

ROSSI, S.; ANTONELLI, M.; MEZZANOFTE, V.; NARIZZO, C. Peracetic acid disinfection: A Feasible Alternative to Wastewater Chlorination. Water Environment Research, Alexandria, v. 79, n. 4, p. 341 - 350, 2007.

RUSSEL, A. D. Mechanisms of Bacterial Resistance to Biocides. International Biodeteriotation \& Biodegradation. p. 247 - 265, 1995.

SILVA, V. N. Biocidas Alternativos em Sistemas de Resfriamento Industrial. Dissertação (Mestrado em Engenharia Ambiental). Universidade Federal do Rio de Janeiro, 70 p, 2013.

SOUZA, J. B. Avaliação de métodos para desinfecção de água empregando cloro, ácido peracético, ozônio e o processo de desinfecção combinado ozônio/cloro. 2006. 190 p. Tese (Doutorado) - Escola de Engenharia de São Carlos, Universidade de São Paulo, São Carlos, 2006.

SOUZA, J .B.; DANIEL, L. A.; Comparação entre Hipoclorito de Sódio e Ácido Peracético na inativação de E.coli, colifagos e C. perfringens em água com elevada concentração de matéria orgânica. v. 10, n. 2, p. 111 - 117, 2005. 
STRITTMATTER, R. J; YANG, B; JOHNSON, D. A. Application of Ozone in Cooling Water Systems. National Association of Corrosion Engineers Corrosion/92, paper n. 347, NACE International, Houston, TX, 1992.

SUZUKI, T. Kurita Handbook of Water Treatment. 2nd English Edition, 1999.

TANJI, Y.; NISHIHARA, T.; MIYANAGA, K. Monitoring of Biofilm in Cooling Water System by Measuring Lactic Acid Consumption Rate. Biochemical Engineering Journal. v. 35. p 81 - 86, 2007.

TELANG, A. J.; EBERT, S.; FOGHT, J. M.; WESTLAKE, D.; VOORDOUW, G. Effects of Two Diamine Biocides on the Microbial Community from an Oil Field. Canadian Journal of Microbiology. n. 44, p. 1060 - 1065, 1998.

TROVATI, J. Tratamento de Águas - Sistemas de Resfriamento. Curso Online. http://www.tratamentodeagua.com.br/curso. Araraquara. SP, 2004.

VEIGA, A. A. Estudo do Efeito Biocida do Cloro e do Peróxido de Hidrogênio em Sistemas de Resfriamento com Reúso de Efluente como Água de Reposição. Tese (Doutorado em Tecnologia dos Processos Químicos e Bioquímicos). Escola de Química, Universidade Federal do Rio de Janeiro, 286 p, 2010.

VIDELA, H. A. Biocorrosão, Biofouling e Biodeterioração de Materiais. São Paulo: Edgard Blucher, 2003. 141 p.

WALSER, S.M; GERSTNER, D.G; BRENNER, B; et. al. Assessing the environmental health relevance of cooling towers - A systematic review of legionellosis outbreaks. Int J Hyg Environ Health 2014; 217:145-54.

WÉRY, N; BRU-ADAN, V; MINERVINI, C.; et. al. Dynamics of Legionella spp. and bacterial populations during the proliferation of $L$. pneumophila in a cooling tower facility. Appl Environ Microbiol, 2008; 74:3030-7. 
XU, P.; XU, Z.; WANG, J.; ZHANG, Y.; ZHANG. L. MIC in Circulating Cooling Water System. Journal of Water Resource and Protection. v. 4, n. 4, p. 203 206, 2012.

ZHAO, X.; ZHANG, T.; ZHOU, Y.; LIU, D. Preparation of Peracetic Acid from Hydrogen Peroxide, Part I: Kinetics for Peracetic Acid Synthesis and Hydrolysis. Journal of Molecular Catalysis A: Chemical, Amsterdam, v. 271, n. 1/2, p. 246-252, 2007. 
ANEXOS

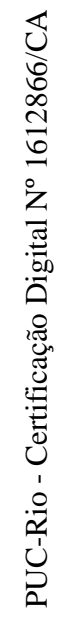


Resultado das contagens microbianas ao longo da campanha de 5 dias em para dosagem inicial de APA de 1,0 mg/L em pH 8,0.

\begin{tabular}{|c|c|c|c|}
\hline Tempo (horas) & $\begin{array}{c}\text { Contagem } \\
\text { microbiana da } \\
\text { amostra } 1 \\
(\mathrm{UFC} / \mathrm{mL})\end{array}$ & $\begin{array}{c}\text { Contagem } \\
\text { microbiana da } \\
\text { amostra } 2 \\
(\mathrm{UFC} / \mathrm{mL})\end{array}$ & $\begin{array}{c}\text { Média } \\
\text { (UFC/mL) }\end{array}$ \\
\hline 0 & $3 \times 10^{6}$ & $3,7 \times 10^{6}$ & $3,35 \times 10^{6}$ \\
\hline 0,083 & $2,06 \times 10^{2}$ & $1,7 \times 10^{2}$ & $1,88 \times 10^{2}$ \\
\hline 1 & $1,1 \times 10^{2}$ & $2,15 \times 10^{2}$ & $1,63 \times 10^{2}$ \\
\hline 2 & $3,66 \times 10^{2}$ & $2,55 \times 10^{2}$ & $3,11 \times 10^{2}$ \\
\hline 4 & $1,26 \times 10^{2}$ & $1,71 \times 10^{2}$ & $1,49 \times 10^{2}$ \\
\hline 24 & $7 \times 10^{6}$ & $1,10 \times 10^{6}$ & $4,05 \times 10^{6}$ \\
\hline 24,083 & $1,10 \times 10^{3}$ & $8,2 \times 10^{2}$ & $9,6 \times 10^{2}$ \\
\hline 25 & $4,1 \times 10^{2}$ & $2,5 \times 10^{2}$ & $3,3 \times 10^{2}$ \\
\hline 26 & $1,3 \times 10^{2}$ & $2,2 \times 10^{2}$ & $1,75 \times 10^{2}$ \\
\hline 28 & $4,8 \times 10^{2}$ & $4 \times 10^{2}$ & $4,4 \times 10^{2}$ \\
\hline 48 & $3,10 \times 10^{6}$ & $4,62 \times 10^{7}$ & $2,47 \times 10^{7}$ \\
\hline 48,083 & $5,4 \times 10^{3}$ & $6 \times 10^{3}$ & $5,7 \times 10^{3}$ \\
\hline 49 & $2,6 \times 10^{3}$ & $2,5 \times 10^{3}$ & $2,55 \times 10^{3}$ \\
\hline 50 & $2,4 \times 10^{3}$ & $5,1 \times 10^{3}$ & $3,75 \times 10^{3}$ \\
\hline 52 & $5,49 \times 10^{2}$ & $1,53 \times 10^{3}$ & $1,04 \times 10^{3}$ \\
\hline 72 & $1 \times 10^{6}$ & $4,62 \times 10^{7}$ & $2,36 \times 10^{7}$ \\
\hline 72,083 & $3,86 \times 10^{3}$ & $6 \times 10^{4}$ & $3,19 \times 10^{4}$ \\
\hline 73 & $4,35 \times 10^{3}$ & $2,5 \times 10^{4}$ & $1,47 \times 10^{4}$ \\
\hline 74 & $2,23 \times 10^{3}$ & $5,1 \times 10^{4}$ & $2,66 \times 10^{4}$ \\
\hline 76 & $2,92 \times 10^{3}$ & $3 \times 10^{4}$ & $1,65 \times 10^{4}$ \\
\hline 96 & $1,14 \times 10^{8}$ & $4,7 \times 10^{7}$ & $8,03 \times 10^{7}$ \\
\hline 96,083 & $5,4 \times 10^{6}$ & $8,88 \times 10^{4}$ & $2,74 \times 10^{6}$ \\
\hline 97 & $4,64 \times 10^{4}$ & $2,62 \times 10^{3}$ & $2,45 \times 10^{4}$ \\
\hline 98 & $2,79 \times 10^{4}$ & $5,2 \times 10^{3}$ & $1,66 \times 10^{4}$ \\
\hline 100 & $9,1 \times 10^{3}$ & $3,36 \times 10^{4}$ & $2,1 \times 10^{4}$ \\
\hline
\end{tabular}


Resultado das contagens microbianas ao longo da campanha de 5 dias em para dosagem inicial de APA de 2,0 mg/L em pH 8,0.

\begin{tabular}{|c|c|c|c|c|}
\hline Tempo (horas) & $\begin{array}{c}\text { Contagem } \\
\text { microbiana da } \\
\text { amostra } 1 \\
(\mathrm{UFC} / \mathbf{m L})\end{array}$ & $\begin{array}{c}\text { Contagem } \\
\text { microbiana da } \\
\text { amostra } 2 \\
(\mathrm{UFC} / \mathrm{mL})\end{array}$ & $\begin{array}{c}\text { Contagem } \\
\text { microbiana da } \\
\text { amostra } 3 \\
(\mathrm{UFC} / \mathrm{mL})\end{array}$ & $\begin{array}{c}\text { Média } \\
\text { (UFC/mL) }\end{array}$ \\
\hline 0 & $1,89 \times 10^{7}$ & $2,5 \times 10^{7}$ & $3,47 \times 10^{7}$ & $2,62 \times 10^{7}$ \\
\hline 0,083 & $2,39 \times 10^{2}$ & $4,66 \times 10^{3}$ & $4,9 \times 10^{2}$ & $1,8 \times 10^{3}$ \\
\hline 1 & $2,10 \times 10^{2}$ & $3,7 \times 10^{2}$ & $5,5 \times 10^{2}$ & $3,77 \times 10^{2}$ \\
\hline 2 & $1,9 \times 10^{2}$ & $3,2 \times 10^{2}$ & $5,9 \times 10^{2}$ & $3,67 \times 10^{2}$ \\
\hline 4 & $1,6 \times 10^{2}$ & $3 \times 10^{2}$ & $5,5 \times 10^{2}$ & $3,37 \times 10^{2}$ \\
\hline 24 & $2,57 \times 10^{7}$ & $2,7 \times 10^{7}$ & $1 \times 10^{6}$ & $1,79 \times 10^{7}$ \\
\hline 24,083 & $1,45 \times 10^{2}$ & $2 \times 10^{2}$ & $3,1 \times 10^{2}$ & $2,18 \times 10^{2}$ \\
\hline 25 & $2 \times 10^{2}$ & $5 \times 10^{2}$ & $4,5 \times 10^{2}$ & $3,83 \times 10^{2}$ \\
\hline 26 & $1,3 \times 10^{2}$ & $3,1 \times 10^{2}$ & $7,8 \times 10^{2}$ & $4,07 \times 10^{2}$ \\
\hline 28 & $2 \times 10^{2}$ & $3,5 \times 10^{2}$ & $5,1 \times 10^{2}$ & $3,53 \times 10^{2}$ \\
\hline 48 & $1 \times 10^{8}$ & $4,1 \times 10^{7}$ & $3,5 \times 10^{7}$ & $5,87 \times 10^{7}$ \\
\hline 48,083 & $4,6 \times 10^{3}$ & $2,310^{3}$ & $2,6 \times 10^{3}$ & $3,17 \times 10^{3}$ \\
\hline 49 & $1 \times 10^{3}$ & $2 \times 10^{3}$ & $1,7 \times 10^{3}$ & $1,57 \times 10^{3}$ \\
\hline 50 & $1,2 \times 10^{3}$ & $5,2 \times 10^{3}$ & $1,7 \times 10^{3}$ & $2,7 \times 10^{3}$ \\
\hline 52 & $1,9 \times 10^{3}$ & $3 \times 10^{3}$ & $2 \times 10^{3}$ & $2,3 \times 10^{3}$ \\
\hline 72 & $3,69 \times 10^{7}$ & $6,2 \times 10^{7}$ & $4 \times 10^{7}$ & $4,63 \times 10^{7}$ \\
\hline 72,083 & $3,4 \times 10^{3}$ & $4,6 \times 10^{3}$ & $3,4 \times 10^{4}$ & $1,4 \times 10^{4}$ \\
\hline 73 & $2,6 \times 10^{3}$ & $1,59 \times 10^{3}$ & $6,3 \times 10^{3}$ & $3,5 \times 10^{3}$ \\
\hline 74 & $6,7 \times 10^{2}$ & $3,3 \times 10^{3}$ & $4,1 \times 10^{3}$ & $2,69 \times 10^{3}$ \\
\hline 76 & $2,79 \times 10^{2}$ & $4,5 \times 10^{3}$ & $1,7 \times 10^{3}$ & $2,16 \times 10^{3}$ \\
\hline 96 & $3 \times 10^{7}$ & $1,1 \times 10^{8}$ & $4,2 \times 10^{7}$ & $6,07 \times 10^{7}$ \\
\hline 96,083 & $4,1 \times 10^{3}$ & $4,7 \times 10^{4}$ & $4 \times 10^{4}$ & $3,04 \times 10^{4}$ \\
\hline 97 & $3,3 \times 10^{4}$ & $3 \times 10^{3}$ & $4,8 \times 10^{4}$ & $2,8 \times 10^{4}$ \\
\hline 98 & $4,5 \times 10^{4}$ & $3,1 \times 10^{3}$ & $4,5 \times 10^{4}$ & $3,1 \times 10^{4}$ \\
\hline 100 & $1,9 \times 10^{3}$ & $2 \times 10^{3}$ & $1,8 \times 10^{3}$ & $1,9 \times 10^{3}$ \\
\hline
\end{tabular}


Resultado das contagens microbianas ao longo da campanha de 5 dias em para dosagem inicial de APA de 1,0 mg/L em pH 8,8.

\begin{tabular}{|c|c|c|c|c|}
\hline Tempo (horas) & $\begin{array}{c}\text { Contagem } \\
\text { microbiana da } \\
\text { amostra } 1 \\
(\mathrm{UFC} / \mathbf{m L})\end{array}$ & $\begin{array}{c}\text { Contagem } \\
\text { microbiana da } \\
\text { amostra } 2 \\
(\mathrm{UFC} / \mathrm{mL})\end{array}$ & $\begin{array}{c}\text { Contagem } \\
\text { microbiana da } \\
\text { amostra } 3 \\
(\mathrm{UFC} / \mathrm{mL})\end{array}$ & $\begin{array}{c}\text { Média } \\
\text { (UFC/mL) }\end{array}$ \\
\hline 0 & $4,5 \times 10^{6}$ & $1,4 \times 10^{6}$ & $8,2 \times 10^{6}$ & $4,7 \times 10^{6}$ \\
\hline 0,083 & $5,1 \times 10^{3}$ & $8,2 \times 10^{3}$ & $5,4 \times 10^{3}$ & $6,23 \times 10^{3}$ \\
\hline 1 & $7 \times 10^{2}$ & $2,41 \times 10^{2}$ & $3,66 \times 10^{2}$ & $4,36 \times 10^{2}$ \\
\hline 2 & $1,46 \times 10^{2}$ & $1,59 \times 10^{2}$ & $2,04 \times 10^{2}$ & $1,7 \times 10^{2}$ \\
\hline 4 & $1,86 \times 10^{2}$ & $2,23 \times 10^{2}$ & $1,41 \times 10^{2}$ & $1,83 \times 10^{2}$ \\
\hline 24 & $1,04 \times 10^{8}$ & $1,6 \times 10^{6}$ & $2,6 \times 10^{6}$ & $3,6 \times 10^{7}$ \\
\hline 24,083 & $8,01 \times 10^{4}$ & $4 \times 10^{3}$ & $4,55 \times 10^{4}$ & $4,32 \times 10^{4}$ \\
\hline 25 & $4,34 \times 10^{3}$ & $5,82 \times 10^{4}$ & $4,3 \times 10^{3}$ & $2,23 \times 10^{4}$ \\
\hline 26 & $2,31 \times 10^{3}$ & $8,1 \times 10^{3}$ & $6,2 \times 10^{3}$ & $2,51 \times 10^{3}$ \\
\hline 28 & $2,32 \times 10^{3}$ & $1,92 \times 10^{3}$ & $3,3 \times 10^{3}$ & $2,51 \times 10^{3}$ \\
\hline 48 & $3,18 \times 10^{7}$ & $9,7 \times 10^{6}$ & $2,9 \times 10^{7}$ & $2,35 \times 10^{7}$ \\
\hline 48,083 & $7 \times 10^{5}$ & $8,2 \times 10^{3}$ & $9,8 \times 10^{3}$ & $2,39 \times 10^{5}$ \\
\hline 49 & $4,3 \times 10^{3}$ & $9,7 \times 10^{3}$ & $4,7 \times 10^{3}$ & $6,23 \times 10^{3}$ \\
\hline 50 & $3,45 \times 10^{3}$ & $8,7 \times 10^{3}$ & $4,6 \times 10^{3}$ & $5,58 \times 10^{3}$ \\
\hline 52 & $3,07 \times 10^{3}$ & $2,35 \times 10^{3}$ & $2,5 \times 10^{3}$ & $2,64 \times 10^{3}$ \\
\hline 72 & $1,18 \times 10^{7}$ & $2,3 \times 10^{6}$ & $1,08 \times 10^{7}$ & $8,3 \times 10^{6}$ \\
\hline 72,083 & $7,57 \times 10^{4}$ & $2,17 \times 10^{4}$ & $8,7 \times 10^{4}$ & $6,15 \times 104$ \\
\hline 73 & $8,15 \times 10^{4}$ & $4 \times 10^{4}$ & $8 \times 10^{4}$ & $6,72 \times 10^{4}$ \\
\hline 74 & $7,38 \times 10^{4}$ & $2,43 \times 10^{4}$ & $9,25 \times 10^{4}$ & $6,35 \times 10^{4}$ \\
\hline 76 & $6,38 \times 10^{4}$ & $3,7 \times 10^{4}$ & $4 \times 10^{4}$ & $4,69 \times 10^{4}$ \\
\hline 96 & $2,03 \times 10^{7}$ & $2,3 \times 10^{6}$ & $6,9 \times 10^{6}$ & $9,83 \times 10^{6}$ \\
\hline 96,083 & $4,03 \times 10^{4}$ & $3,15 \times 10^{4}$ & $6,02 \times 10^{4}$ & $4,4 \times 10^{4}$ \\
\hline 97 & $6,10 \times 10^{4}$ & $5,03 \times 10^{4}$ & $3,6 \times 10^{4}$ & $3,68 \times 10^{4}$ \\
\hline 98 & $1,41 \times 10^{4}$ & $3,02 \times 10^{4}$ & $8 \times 10^{4}$ & $4,14 \times 10^{4}$ \\
\hline 100 & $3,39 \times 10^{4}$ & $1,28 \times 10^{4}$ & $9,21 \times 10^{4}$ & $4,63 \times 10^{4}$ \\
\hline
\end{tabular}


Resultado das contagens microbianas ao longo da campanha de 5 dias em para dosagem inicial de APA de 2,0 mg/L em pH 8,8.

\begin{tabular}{|c|c|c|c|c|}
\hline Tempo (horas) & $\begin{array}{c}\text { Contagem } \\
\text { microbiana da } \\
\text { amostra } 1 \\
(\mathrm{UFC} / \mathrm{mL})\end{array}$ & $\begin{array}{c}\text { Contagem } \\
\text { microbiana da } \\
\text { amostra } 2 \\
(\mathrm{UFC} / \mathrm{mL})\end{array}$ & $\begin{array}{c}\text { Contagem } \\
\text { microbiana da } \\
\text { amostra } 3 \\
(\mathrm{UFC} / \mathrm{mL})\end{array}$ & $\begin{array}{c}\text { Média } \\
\text { (UFC/mL) }\end{array}$ \\
\hline$\overline{0}$ & $1,2 \times 10^{6}$ & $1,2 \times 10^{6}$ & $2,1 \times 10^{6}$ & $1,5 \times 10^{6}$ \\
\hline 0,083 & $4,41 \times 10^{3}$ & $7 \times 10^{2}$ & $4 \times 10^{2}$ & $1,84 \times 10^{3}$ \\
\hline 1 & $2,28 \times 10^{2}$ & $2 \times 10^{2}$ & $1,29 \times 10^{2}$ & $1,86 \times 10^{2}$ \\
\hline 2 & $1,2 \times 10^{2}$ & $1,4 \times 10^{2}$ & $1,7 \times 10^{2}$ & $1,43 \times 10^{2}$ \\
\hline 4 & $1,23 \times 10^{2}$ & $2,22 \times 10^{3}$ & $1,02 \times 10^{2}$ & $2,24 \times 10^{2}$ \\
\hline 24 & $4,76 \times 10^{7}$ & $6 \times 10^{7}$ & $4,21 \times 10^{7}$ & $4,99 \times 10^{7}$ \\
\hline 24,083 & $1,15 \times 10^{4}$ & $2,31 \times 10^{4}$ & $2,56 \times 10^{2}$ & $1,16 \times 10^{4}$ \\
\hline 25 & $3,31 \times 10^{2}$ & $4,58 \times 10^{2}$ & $3,47 \times 10^{2}$ & $3,79 \times 10^{2}$ \\
\hline 26 & $2,22 \times 10^{2}$ & $3,27 \times 10^{2}$ & $2,11 \times 10^{2}$ & $2,53 \times 10^{2}$ \\
\hline 28 & $1,56 \times 10^{2}$ & $2,18 \times 10^{2}$ & $1,98 \times 10^{2}$ & $1,91 \times 10^{2}$ \\
\hline 48 & $3,39 \times 10^{7}$ & $7,21 \times 10^{7}$ & $4,59 \times 10^{7}$ & $5,06 \times 10^{7}$ \\
\hline 48,083 & $3,24 \times 10^{2}$ & $3,34 \times 10^{3}$ & $2,47 \times 10^{3}$ & $2,04 \times 10^{3}$ \\
\hline 49 & $2,37 \times 10^{2}$ & $4,1 \times 10^{2}$ & $3,19 \times 10^{2}$ & $3,22 \times 10^{2}$ \\
\hline 50 & $4 \times 10^{2}$ & $2,79 \times 10^{2}$ & $2,44 \times 10^{2}$ & $3,08 \times 10^{2}$ \\
\hline 52 & $2,21 \times 10^{2}$ & $1,44 \times 10^{2}$ & $1,78 \times 10^{2}$ & $1,81 \times 10^{2}$ \\
\hline 72 & $5 \times 10^{7}$ & $3,2 \times 10^{7}$ & $3,83 \times 10^{7}$ & $4,01 \times 10^{7}$ \\
\hline 72,083 & $9 \times 10^{4}$ & $7,1 \times 10^{4}$ & $9,8 \times 10^{4}$ & $8,63 \times 10^{4}$ \\
\hline 73 & $7,92 \times 10^{4}$ & $8,35 \times 10^{4}$ & $7 \times 10^{4}$ & $7,76 \times 10^{4}$ \\
\hline 74 & $8 \times 10^{4}$ & $8,5 \times 10^{4}$ & $9 \times 10^{4}$ & $8,5 \times 10^{4}$ \\
\hline 76 & $4,49 \times 10^{4}$ & $7,8 \times 10^{4}$ & $8,43 \times 10^{4}$ & $6,91 \times 10^{4}$ \\
\hline 96 & $5,4 \times 10^{7}$ & $4,2 \times 10^{7}$ & $2,7 \times 10^{7}$ & $4,1 \times 10^{7}$ \\
\hline 96,083 & $8,4 \times 10^{4}$ & $7 \times 10^{4}$ & $9,53 \times 10^{4}$ & $8,31 \times 10^{4}$ \\
\hline 97 & $7,84 \times 10^{4}$ & $7,1 \times 10^{4}$ & $8,1 \times 10^{4}$ & $7,68 \times 10^{4}$ \\
\hline 98 & $8,01 \times 10^{4}$ & $8,6 \times 10^{4}$ & $8,2 \times 10^{4}$ & $8,27 \times 10^{4}$ \\
\hline 100 & $6,78 \times 10^{4}$ & $8 \times 10^{4}$ & $5,6 \times 10^{4}$ & $6,79 \times 10^{4}$ \\
\hline
\end{tabular}

